\title{
Radical Truce-Smiles reactions on an isoxazole template: scope and limitations
}

DOI:

10.1016/j.tet.2019.03.015

\section{Document Version}

Accepted author manuscript

Link to publication record in Manchester Research Explorer

\section{Citation for published version (APA):}

Rashid, S., Almadhhi, S., Berrisford, D., Raftery, J., Vitorica-Yrezabal, I., Whitehead, G., \& Quayle, P. (2019). Radical Truce-Smiles reactions on an isoxazole template: scope and limitations. Tetrahedron. https://doi.org/10.1016/j.tet.2019.03.015

\section{Published in:}

Tetrahedron

\section{Citing this paper}

Please note that where the full-text provided on Manchester Research Explorer is the Author Accepted Manuscript or Proof version this may differ from the final Published version. If citing, it is advised that you check and use the publisher's definitive version.

\section{General rights}

Copyright and moral rights for the publications made accessible in the Research Explorer are retained by the authors and/or other copyright owners and it is a condition of accessing publications that users recognise and abide by the legal requirements associated with these rights.

\section{Takedown policy}

If you believe that this document breaches copyright please refer to the University of Manchester's Takedown Procedures [http://man.ac.uk/04Y6Bo] or contact uml.scholarlycommunications@manchester.ac.uk providing relevant details, so we can investigate your claim.

\section{OPEN ACCESS}




\section{Graphical Abstract}

To create your abstract, type over the instructions in the template box below.

Fonts or abstract dimensions should not be changed or altered.

\section{Radical Truce-Smiles reactions on an isoxazole}

template: scope and limitations

Srood Omer Rashidd, ${ }^{\text {a,bc }}$, Sultan Saad Almadhhi, ${ }^{a}$ David J. Berrisford, ${ }^{a}$ James Raftery, ${ }^{\text {a }}$ Inigo Vitorica-Yrezabal, George Whitehead and Peter Quayle ${ }^{\text {a* }}$

${ }^{a}$ School of Chemistry, University of Manchester, Oxford Road, Manchester M13 9PL, UK.

${ }^{b}$ Department of Chemistry, College of Science, University of Sulaimani, Sulaimanyah, Kurdistan Region, Iraq ${ }^{c}$ Komar Research Center (KRC), Komar University of Science and Technology, Sarchinar, Qularaisi District, Sulaimani, 46001, Kurdistan Region, Iraq.
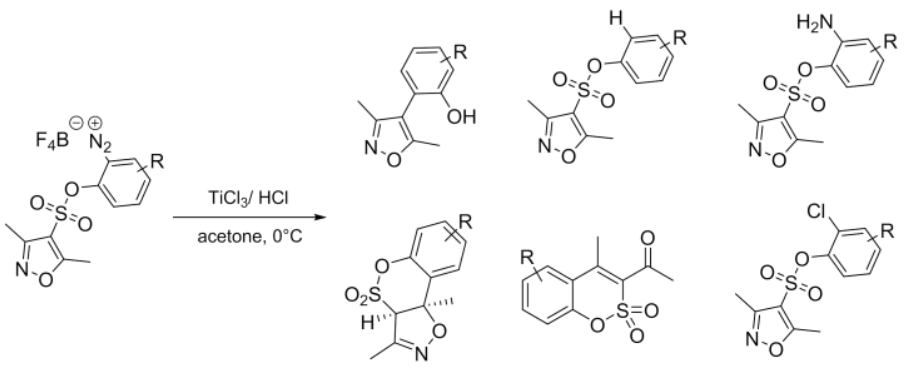


\title{
Radical Truce-Smiles reactions on an isoxazole template: scope and limitations
}

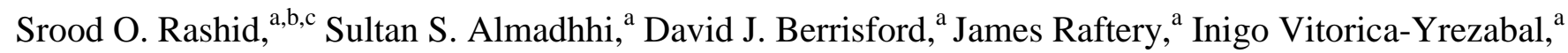 \\ George Whitehead $^{\mathrm{a}}$ and Peter Quayle ${ }^{\mathrm{a} *}$
}

${ }^{a}$ School of Chemistry, University of Manchester, Oxford Road, Manchester M13 9PL, UK.

${ }^{b}$ Chemistry Department, College of Science, University of Sulaimani, Sulaimanyah, Kurdistan Region, Iraq.

${ }^{c}$ Komar Research Center (KRC), Komar University of Science and Technology, Sarchinar, Qularaisi District, Sulaimani, 46001, Kurdistan

Region, Iraq.

\section{ARTICLE INFO}

Article history:

Received

Received in revised form

Accepted

Available online

\section{Keywords:}

$\mathrm{TiCl}_{3}$

Truce-Smiles rearrangement

Biaryl

Radical chemistry

Diazonium

\section{ABSTRACT}

The use of $\mathrm{TiCl}_{3}-\mathrm{HCl}$ as promotor in the radical Truce-Smiles reactions of 2-(( $(3,5-$ dimethylisoxazol-4-yl)sulfonyl)oxy)benzenediazonium salts has been investigated in detail. During these reactions the desired Truce-Smiles rearrangement (via an ipso-substitution reaction) is accompanied by the formation of a number of by-products including dihydrobenzo[5,6][1,2] oxathiino[3,4-d]isoxazole 4,4-dioxides, dioxidobenzo[e][1,2]oxathiin-3yl)ethan-1-ones, anilines and chloroaromatics. Replacing $\mathrm{TiCl}_{3}-\mathrm{HCl}$ by $\mathrm{Cu}\left(\mathrm{NO}_{3}\right)_{2}-\mathrm{Cu}_{2} \mathrm{O}$ as reductant in these reactions was found to afford broadly comparable product distributions. Competition and radical clock experiments also provide an indication of the relative susceptibility of the isoxazole nucleus towards attack by aryl radicals.

2009 Elsevier Ltd. All rights reserved.

\section{Introduction}

The Truce-Smiles rearrangement represents a general reaction which, in its original form, results in the intramolecular ipsosubstitution reaction of a suitably activated aromatic ring system by a pendant nucleophile. ${ }^{1}$ The versatility of this reaction is due, in part, to the broad range of substrates that are found to participate in this transformation, which leads to the generation of new aryl C-C, C-O and C-N bonds (Scheme 1). ${ }^{2}$

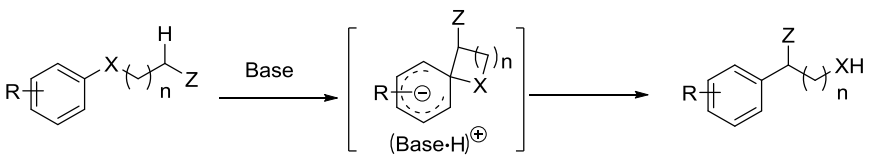

Scheme 1: A generalized Truce-Smiles rearrangement reaction.

More recently, Smiles-type rearrangements have been shown to proceed on seemingly unactivated substrates, an advance which has found particular application in the synthesis of sterically hindered, quaternary, centres where it has been found that the rearrangements proceed with some degree of stereochemical control. $^{3}$ In addition, the invention of new cascade sequences in which Smiles-type reactions are integral, as cogently adumbrated by Greaney, ${ }^{4}$ has much synthetic potential. While most Smiles-type rearrangements were restricted to anionic, $\mathrm{S}_{\mathrm{N}} \mathrm{Ar}$-processes, the seminal observation by Speckamp ${ }^{5 \mathrm{a}}$ concerning a free-radical ${ }^{5 \text {-d }}$ variant has recently become an area of resurgent interest. Most notably, advancements in this area include the development of tandem cyclization-displacement cascades which enable the synthesis of polycyclic systems from simple, acyclic, starting materials. ${ }^{6}$ Germaine to the present study is Motherwell's ${ }^{7}$ report of radical Truce-Smiles reactions leading to the synthesis of bi-aryls, a process which is devoid of the now ubiquitous transition-metal-catalyzed cross-coupling cycle. Pivotal to this transformation is the generation of an aryl radical, most commonly from a suitably functionalized aryl halide, via the auspices of a one-electron reducing agent. At the time of Speckamp's and Motherwell's initial investigations the use of reducing agents such as tri- $n$-butyltin hydride was commonplace, ${ }^{8 \mathrm{a}}$ however environmental considerations have meant that the use of this reagent is now frowned upon, and is often replaced by more environmentally friendly reagents such as tris(trimethylsilyl)silane (TTMSS). ${ }^{8 \mathrm{~b}, \mathrm{c}}$ Given the facile reduction of diazonium salts to aryl radicals ${ }^{9}$ we wished to capitalize on Motherwell's observation that radical-mediated Truce-Smiles rearrangements can be triggered by the reaction between an aryl diazonium salt and a benign reducing agent such as $\mathrm{Ti}(\mathrm{III})-\mathrm{HCl}{ }^{10}$ To our knowledge, the use of diazonium salts, as radical precursors, in Truce-smiles rearrangements has only one other citation, that by Lesur and co-workers, ${ }^{11 \mathrm{a}, \mathrm{b}}$ in the patent literature, where it is reported that ortho-hydroxy-biaryls were accessible using Motherwell's chemistry, Scheme 2. The phlegmatic development of this variant of the Truce-Smiles rearrangement ${ }^{12 a}$ is all the more surprising given the intense interest in the use of 
related Meeerwein arylation ${ }^{12 \mathrm{~b}, \mathrm{c}, \mathrm{d}, \mathrm{e}}$ and palladium-catalyzed reactions. ${ }^{12 \mathrm{f}, \mathrm{g}}$

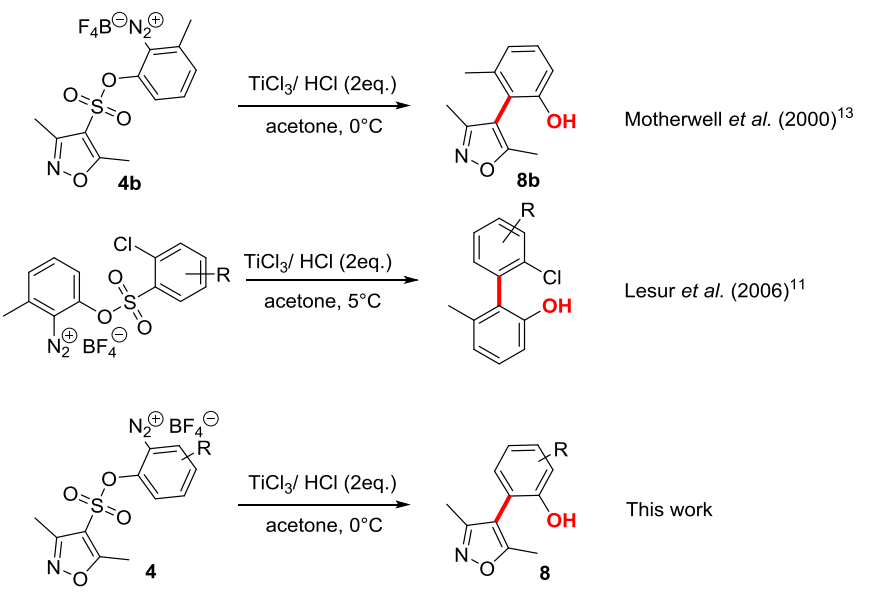

Scheme 2: The Motherwell modification of the radical Truce-Smiles rearrangement.

\section{Results and discussion}

In 2000 Motherwell reported, ${ }^{13}$ as a sole example, that exposure of the isoxazole-derived diazonium salt $\mathbf{4 b}$ to commercially available $\mathrm{TiCl}_{3}-\mathrm{HCl}$ resulted in the isolation of hetero-biaryl $\mathbf{8 b}$, an outcome that can best be described as a radical Truce-Smiles rearrangement reaction (Scheme 2). Given the ready availability of diazonium salts we wished to determine the scope and limitations of this radical-mediated rearrangement reaction. Specifically we required access to a variety of arylsubstituted isoxazoles ${ }^{14}$ for biological testing and the Motherwell protocol appeared to be ideal for this purpose, even though there is only limited precedent for the use of isoxazoles as "acceptors" in radical-mediated Truce-Smiles rearrangements, Scheme 2. In this paper we present our initial findings concerning the use of aqueous $\mathrm{TiCl}_{3}$ as a promotor for radical Truce-Smiles rearrangements in which aryl diazonium salts are employed as the radical precursors.

\subsection{Synthesis of radical precursors}

As an initial survey, a series of ortho-aminoarenesulfonate esters 3a-e was prepared by reaction of sulfonyl chloride $\mathbf{1}^{15}$ with amino phenols 2a-e in the presence of a suitable base (using either aqueous $\mathrm{NaOH}$ or $\mathrm{Et}_{3} \mathrm{~N}$ ) and their conversion into the stable arenediazonium salts $\mathbf{4 a - e}$ was successfully accomplished upon reaction with $\mathrm{HBF}_{4}$ in the presence of iso-amyl nitrite (Figure 1). ${ }^{16}$ For completeness sake the regioselectivity in the initial ester-formation step was confirmed, in the case of $\mathbf{3 a}, \mathbf{3 b}$, $\mathbf{3 c}$ and $\mathbf{3 e}$, by way of single crystal X-ray structure determinations, as depicted in Figure 2.

\section{2. $\mathrm{TiCl}_{3}-\mathrm{HCl}$ promoted reactions of diazonium salts $\mathbf{4 a - e}$}

Having gained access to a representative selection of diazonium salts we then embarked upon an investigation into the pivotal Ti-induced rearrangement reaction. In practice, addition of commercially available $\mathrm{TiCl}_{3}-\mathrm{HCl}\left(1.29 \mathrm{M} \mathrm{TiCl}_{3}\right.$ in $2 \mathrm{M} \mathrm{HCl}$; 2 eq) to $\mathbf{4 a - d}$ in acetone at $0{ }^{\circ} \mathrm{C}$, under an atmosphere of nitrogen, resulted in the generation of complex reaction mixtures. ${ }^{16}$ Apart from the desired rearrangement process these reactions were accompanied by the isolation of a number of by-products, in which the exact product profile was highly dependent upon substrate and reaction conditions, as summarized in Scheme 3.

\subsubsection{Pathway A: [1, 5] ipso-substitution reaction leading to rearranged products}

It is understood that the reduction of diazonium salts such as
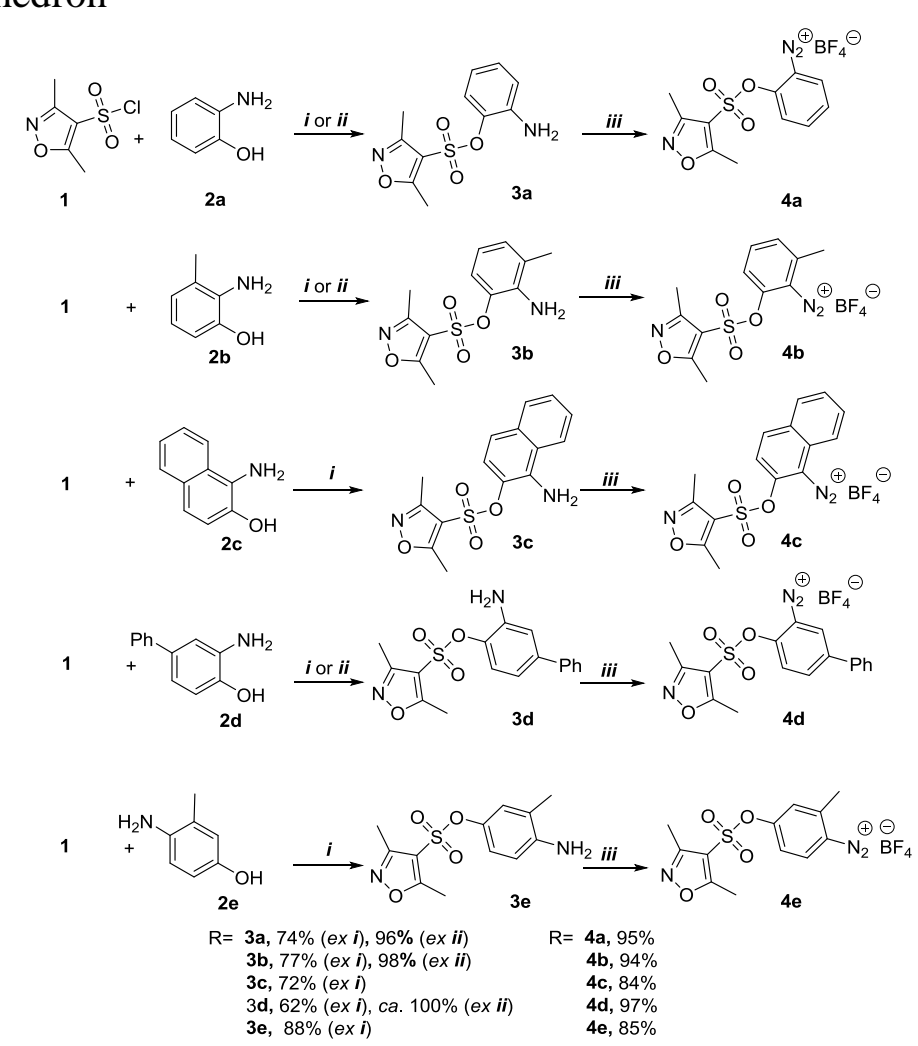

Figure 1: Preparation of substrates 4a-4e. Reagents and conditions: $\boldsymbol{i} \mathrm{NaOH}$ (1 eq.); 1 (1 eq.); $\mathrm{CH}_{2} \mathrm{Cl}_{2} ; 0{ }^{\circ} \mathrm{C}$; ii $\mathrm{Et}_{3} \mathrm{~N}$ (1.1 eq.); 1 (1 eq.); $\mathrm{CH}_{2} \mathrm{Cl}_{2} ; 0{ }^{\circ} \mathrm{C}$; iii $\mathrm{HBF}_{4}$ (2.6 eq.); iso-amyl nitrite (1.2 eq.); $\mathrm{EtOH} ; 0{ }^{\circ} \mathrm{C}$.

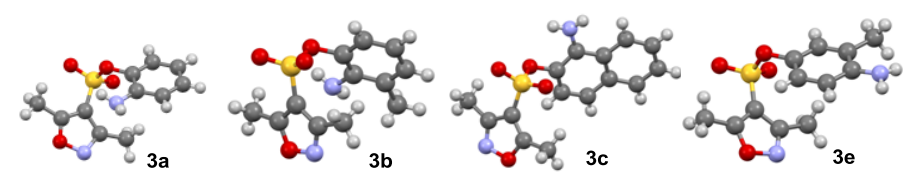

Figure 2: Single crystal X-ray structures of $\mathbf{3 a}, \mathbf{3 b}, \mathbf{3 c}$ and $\mathbf{3 e}$.

Scheme 3: Products derived from the reaction between $\mathbf{4 a - d}$ with $\mathrm{TiCl}_{3}$.

4a-e by $\mathrm{TiCl}_{3}$ proceeds by way of a single electron transfer

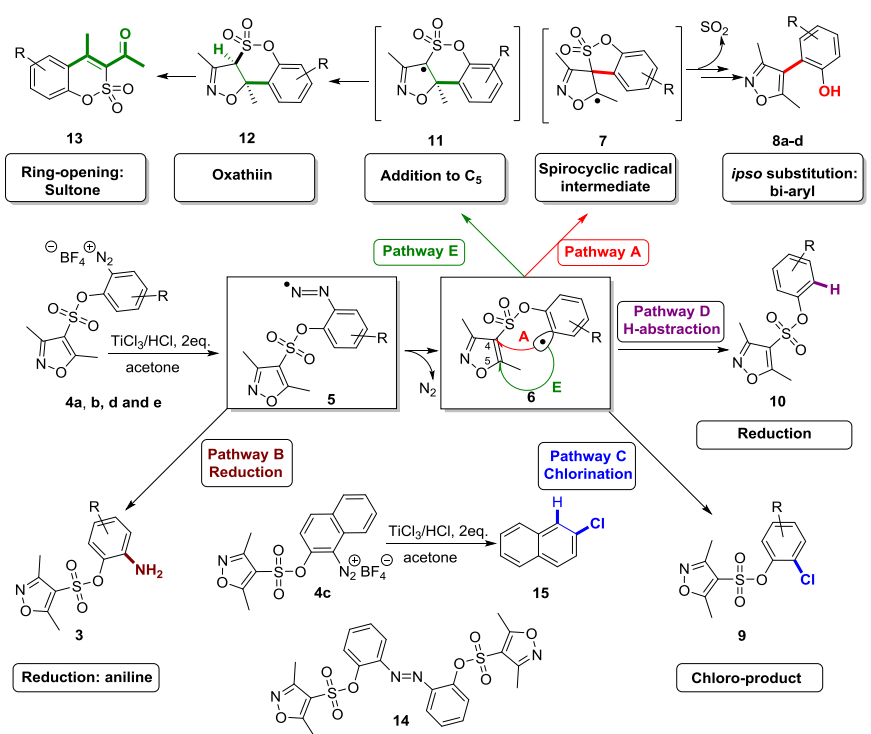

(SET) process $^{17}$ producing aryldiazenyl radicals, Aryl-N=N•, 5 and that subsequent partitioning of these intermediates then dictates the observed product distribution. In the present case, fragmentation of 5 to the aryl radicals ${ }^{18} \mathbf{6}$ ultimately results in the Truce-Smiles rearrangement. This outcome is observed when the intermediate radicals $\mathbf{6}$ are able to undergo intramolecular ipsosubstitution at the $\mathrm{C}_{4}$-sulfonyl-bearing carbon in the acceptor, isoxazole, ring (Scheme 3: pathway $\mathbf{A}$ ) in preference to other competing processes (Scheme 3, pathways B to E). From the 
results that we have generated so far it appears that the incorporation of a bulky group, close to the radical centre of $\mathbf{6}$, promotes 1,5-ipso-substitution via spirocyclic intermediates 7 which upon re-aromatization, by extrusion of $\mathrm{SO}_{2}$, followed by $\mathrm{H}$-atom abstraction, led to the formation of isoxazoles $8 \mathbf{a}(14 \%)$, 8b $(68 \%)$, 8c (20\%) and 8d (26\%), (Pathway A, Scheme 3). These observations are in accord with those reported by Motherwell where bulky substituents positioned close to the reacting centre promote the formation of a hindered biaryl axis by way of the "enforced orthogonality" concept. ${ }^{19}$ Support for this hypothesis is manifested in the single crystal X-ray structures of $\mathbf{8 b}, \mathbf{8 c}$ and $\mathbf{8 d}$, the products of Truce-Smiles rearrangement, which possess torsion angles about the biaryl axis of $92.38^{\circ}$, $114.05^{\circ}$ and $92.57^{\circ}$ respectively in the solid state (Figure 3 ). In those cases where ipso-substitution does not appear to be favoured alternate reaction pathways intervene, as discussed below.
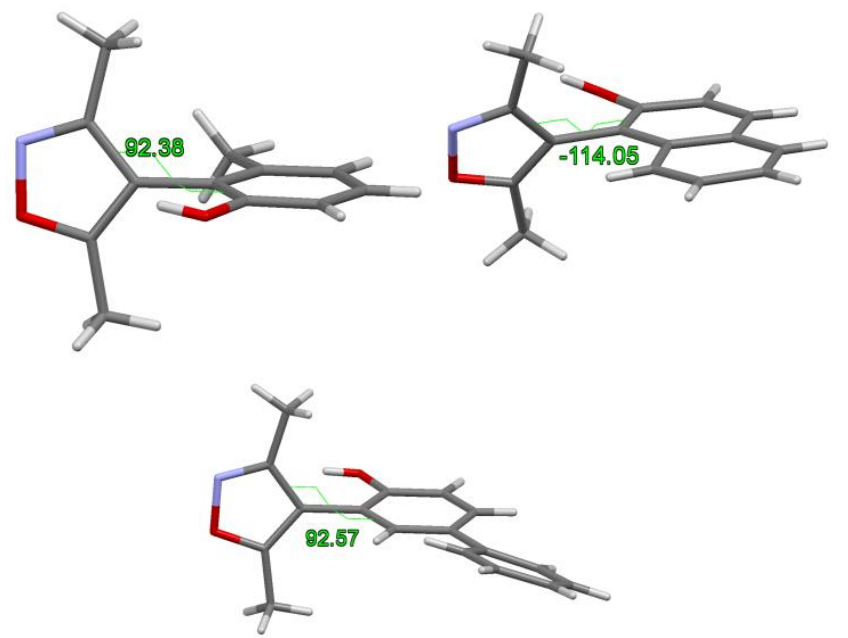

Figure 3: Single crystal X-ray structures of $\mathbf{8 b}, \mathbf{8 c}$ and $\mathbf{8 d}$

\subsubsection{Pathway B: $\mathrm{TiCl}_{3}$ - mediated reduction: aniline formation}

During our screening of the use of $\mathrm{TiCl}_{3}$ as a trigger for the Truce-Smiles rearrangement we were somewhat surprised to note occasional complications in the generation of radicals $\mathbf{6}$ from 5 . For example, in the case of $\mathbf{4 a}$ reaction with $\mathrm{TiCl}_{3}$ led to the formation of $\mathbf{3 a}$ in low, but reproducible, yield (10\%), Scheme 4. In addition to the the isolation of aniline $\mathbf{3 a}$, this rearrangement was also accompanied by the formation of 10a, 12a and 13a whose structures were confirmed by single crystal X-ray diffraction studies. The reductive cleavage reaction leading to $\mathbf{3 a}$ appears to be substrate dependent and was not observed in the case of 4b-4e. However we later observed that this reduction process can become the major reaction pathway which may ultimately limit the generality of the Ti(III)-methodology for the generation of aryl radicals from diazonium salts (see section 2.2.6, Schemes 14 and 15). Somewhat surprisingly, prior to our observations we were not aware of any other reports concerning the generation of anilines during the $\mathrm{TiCl}_{3}$ - mediated reduction of diazonium salts, although it had been noted by Heinrich and co-workers $^{20}$ that aryldiazenes can disproportionate to anilines, along with other products, under acidic conditions. In passing we also note that the generation of $\mathbf{3 a}$ could also proceed via the intermediacy of the azo-aromatic $\mathbf{1 4}$ (Scheme 3), derived from the initial coupling of $\mathbf{5 a}$ with $\mathbf{6 a}$, followed by reduction ${ }^{21}$ with $\mathrm{TiCl}_{3}$, a possibility which has yet to be scrutinized in this context.

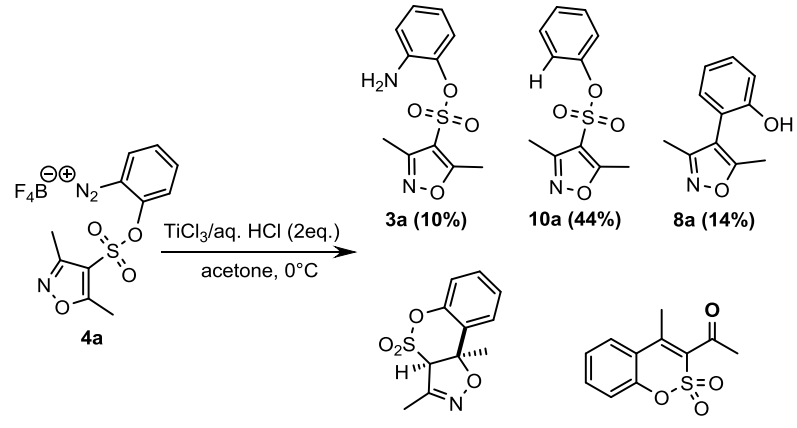

12a $(15 \%) \quad 13 a(14 \%)$
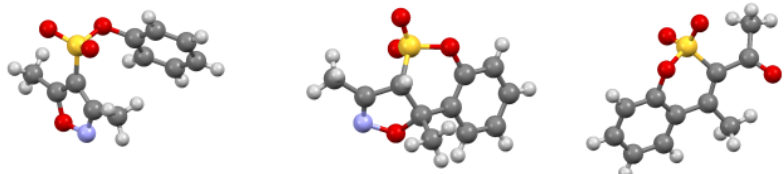

Scheme 4: Product distribution from the reduction of $\mathbf{4 a}$ with $\mathrm{TiCl}_{3}$ together with the X-ray structures of $10 \mathbf{a}, \mathbf{1 2} \mathbf{a}$ and $\mathbf{1 3 a}$

\subsubsection{Pathway C: Chlorination}

During the course of these investigations we also observed that reaction of $\mathbf{4 b}$ with $\mathrm{TiCl}_{3}$ afforded the chlorinated product $\mathbf{9 b}$ in $11 \%$ isolated yield in addition to the desired Truce-Smiles product $\mathbf{8 b}$ in $68 \%$ yield (Scheme 5). Although the transformation of aryl diazonium salts into aryl halides, via the auspices of metal salts, principally those derived from copper, is embodied in the classical Sandmeyer reaction, ${ }^{22}$ the interception of aryl radicals by titanium halides in such a fashion has, to our knowledge little literature precedent, although Beringer noted similar SET-ligand transfer processes during the reaction between aryliodonium salts and aqueous $\mathrm{TiCl}_{3}{ }^{23}$ In the case of $4 \mathbf{b}$ we presume that SET from $\mathrm{TiCl}_{3}$ resulted in the generation of

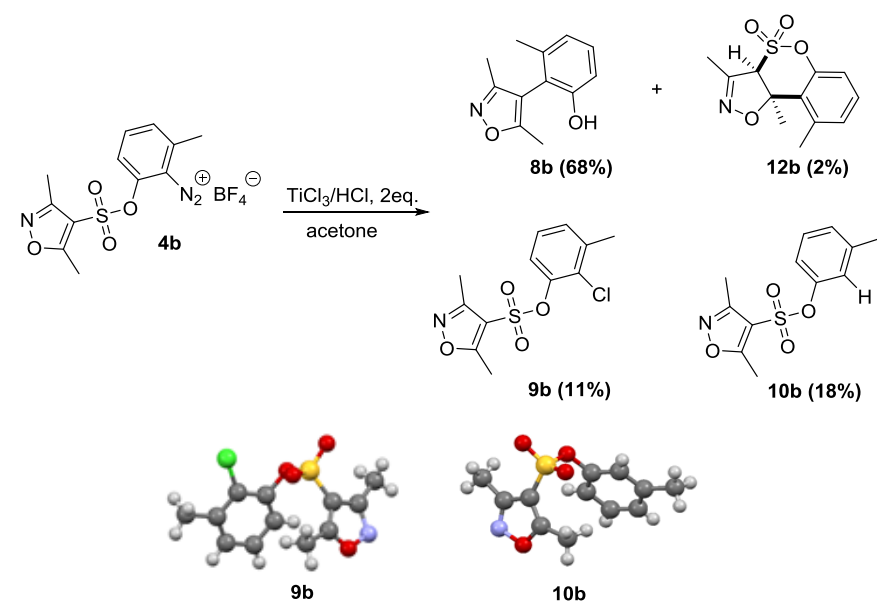

Scheme 5: Product distribution from the reduction of $\mathbf{4 b}$ with $\mathrm{TiCl}_{3}$ together with the X-ray structures of $\mathbf{9 b}$ and $\mathbf{1 0 b}$

radical intermediate $\mathbf{6 b}$ whose partitioning, either via a TruceSmiles manifold (Scheme 3, pathway A) or halogen transfer process (Scheme 3, pathway C) could ultimately lead to the isolation of $\mathbf{9 b}$, a process which competes favourably with the formation of $\mathbf{8 b}$. The generation of $\mathbf{8 b}$ and $\mathbf{9 b}$ was also accompanied by the formation of $\mathbf{1 0 b}$ ( $18 \%$ isolated yield), presumably the result of $\mathrm{H}$-abstraction from solvent (acetone) and a minor quantity of the oxathiin $\mathbf{1 2 b}(2 \%$; stereochemistry by analogy) whose generation of which is discussed in section 2.2.5. Unambiguous structural assignments for $\mathbf{8 b}, \mathbf{9 b}$ and $\mathbf{1 0 b}$ were 
obtained by way of single crystal X-ray structure determinations (Scheme 5 and Figure 3).

Interestingly the blank reaction between $\mathbf{4 b}$ with an excess $(16 \mathrm{eq})$ of $\mathrm{HCl}(3 \mathrm{M})$ in acetone also afforded the chloro-aromatic 9b $(18 \%)$, plausibly via an $\mathrm{S}_{\mathrm{N}} 1$-type process, ${ }^{24 a}$ together with the reduced product $\mathbf{1 0 b}(13 \%)$ and the rearranged bi-aryl $\mathbf{8 b}(2 \%)$, Scheme 6. Evidently radical generation is therefore still operative in this case to a limited extent, even in the absence of titanium(III). However, it is not possible therefore at the present stage to determine whether the isolation of the chlorinated product $9 \mathbf{b}$, during the $\mathrm{TiCl}_{3}$-promoted rearrangement reaction of $\mathbf{4 b}$, is the result of a ligand transfer reaction ${ }^{24 b, c}$ of a Ti(IV) species or through the interception of an aryl cation with the $\mathrm{HCl}$ that is present in the reaction medium.
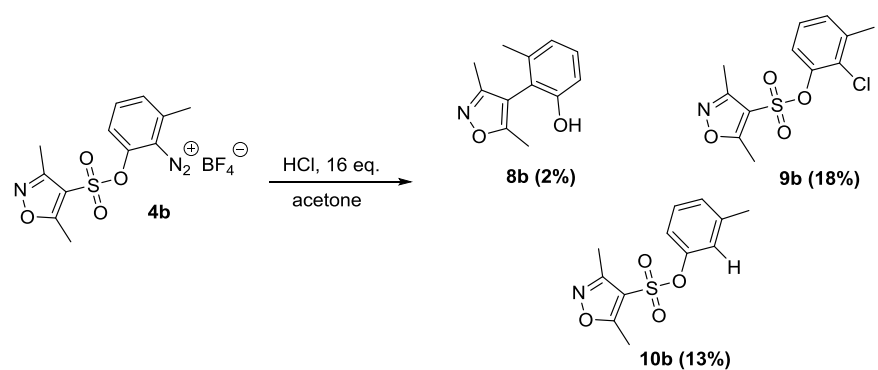

$9 b(18 \%)$

Scheme 6: Product distribution from the blank reaction between $\mathbf{4 b}$ and $\mathrm{HCl}$.

As noted above (section 2.2.1), the $\mathrm{TiCl}_{3}$-promoted rearrangement of $\mathbf{4 c}$ afforded the biaryl $\mathbf{8 c}$ in only meagre yield $(20 \%)$. Quite unexpectedly (Scheme 7), the major product of this reaction proved to be 2-chloronaphthalene, 15 (63\%) which was isolated together with minor quantities of the reduction product

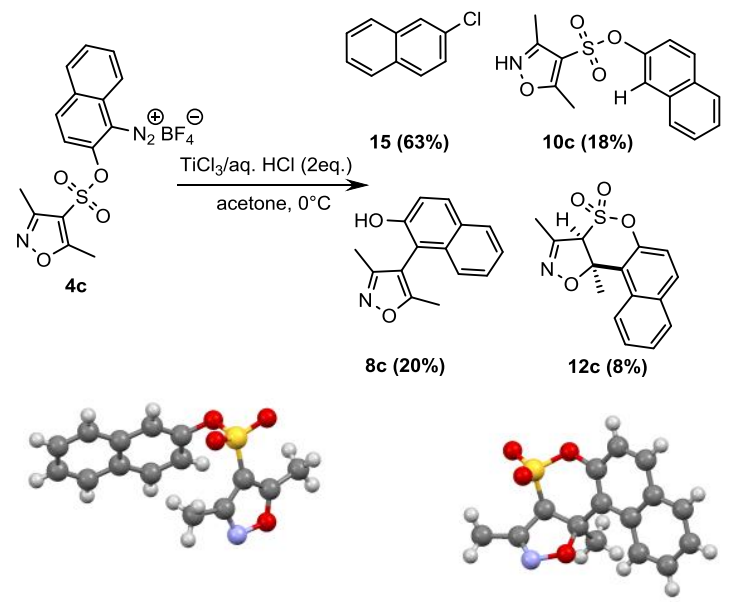

Scheme 7: Product distribution from the reduction of $\mathbf{4 c}$ with $\mathrm{TiCl}_{3}$ together with the X-ray structures for 10c and 12c.

10c $(18 \%)$ and the sultone $12 \mathrm{c}(8 \%)$, whose structures were again confirmed by single crystal X-ray analysis, Scheme 7 .

Intrigued as to the formation of $\mathbf{1 5}$ we again embarked upon a series of blank reactions in order to gain insights into the mechanism of its generation (Scheme 8). It was quickly established that both sulphonate 10c and 2-naphthol $\mathbf{1 6}$ were isolated, unchanged, upon exposure to the standard reduction conditions using $\mathrm{TiCl}_{3}$. Somewhat surprising however, reaction of $4 \mathbf{c}$ with $3 \mathrm{M} \mathrm{HCl}$ in the absence of $\mathrm{TiCl}_{3}$ resulted in the isolation of the known ${ }^{25}$ diazo-ketone $\mathbf{1 7}$ in good overall yield (68\%). Diazo-ketone 17 was also isolated, again in good yield (71\%), from the reaction between $4 \mathbf{c}$ and $\mathrm{Cu}\left(\mathrm{NO}_{3}\right)_{2}-\mathrm{Cu}_{2} \mathrm{O}$, a system which usually promotes hydroxy-dediazotization ${ }^{26}$ ("phenolverkochung") of aryl diazonium salts to phenols. That diazo-ketone 17 was not an intermediate in the $\mathrm{TiCl}_{3}$-promoted conversion of $\mathbf{4 c}$ into $\mathbf{1 5}$ was shown to be the case as reaction between a purified sample of $\mathbf{1 7}$ and $\mathrm{TiCl}_{3}$ afforded a mixture of 2-naphthol, 16 and 1-chloro-2-naphthol, 18 in $63 \%$ and $31 \%$ isolated yield respectively. Further blank experiments also indicated that diazo-ketone $\mathbf{1 7}$ is relatively stable towards $3 \mathrm{M}$ $\mathrm{HCl}$ in the absence of $\mathrm{TiCl}_{3}$. Evidently, reaction of $\mathbf{4 c}$ with either $3 \mathrm{M} \mathrm{HCl}$ or $\mathrm{Cu}\left(\mathrm{NO}_{3}\right)_{2}-\mathrm{Cu}_{2} \mathrm{O}$ results in hydrolysis of the sulfonate ester and ultimately leads to the generation of $17 .^{27}$
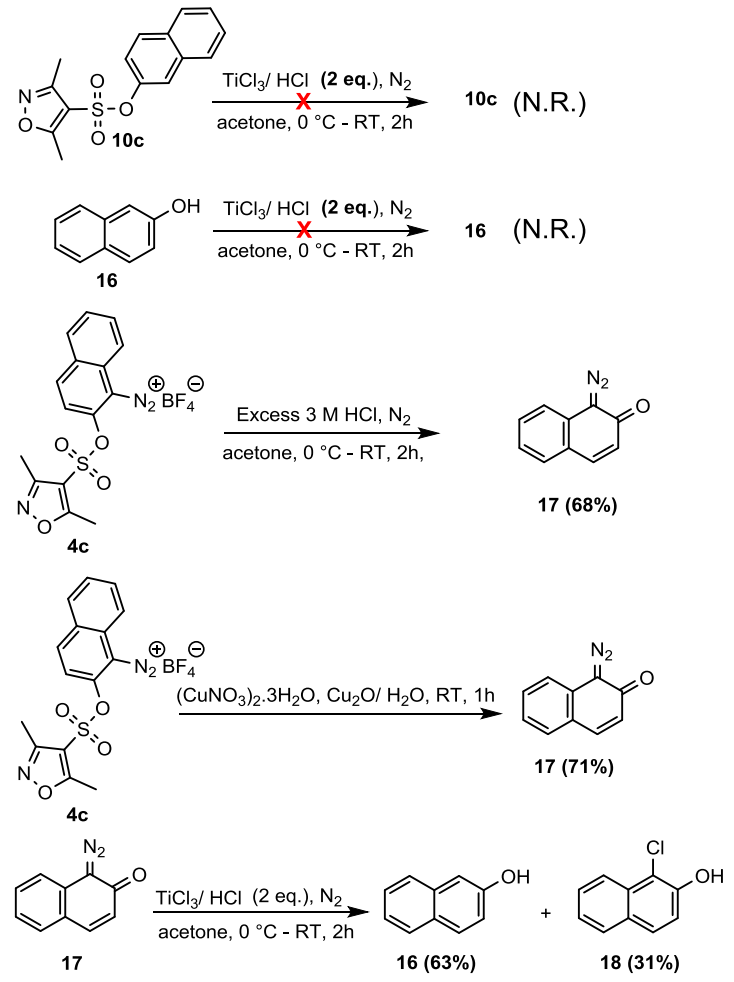

Scheme 8: Conversion of $4 c$ into 15 : blank reactions.

In terms of the conversion of $\mathbf{4 c}$ into $\mathbf{1 5}$ the activating ("nuisance") ${ }^{28}$ effect of the diazonium group in Sandmeyer-type reactions is in fact a documented, but often overlooked complication. It is not uncommon to observe the formation of products arising from displacement reactions of aryl diazonium

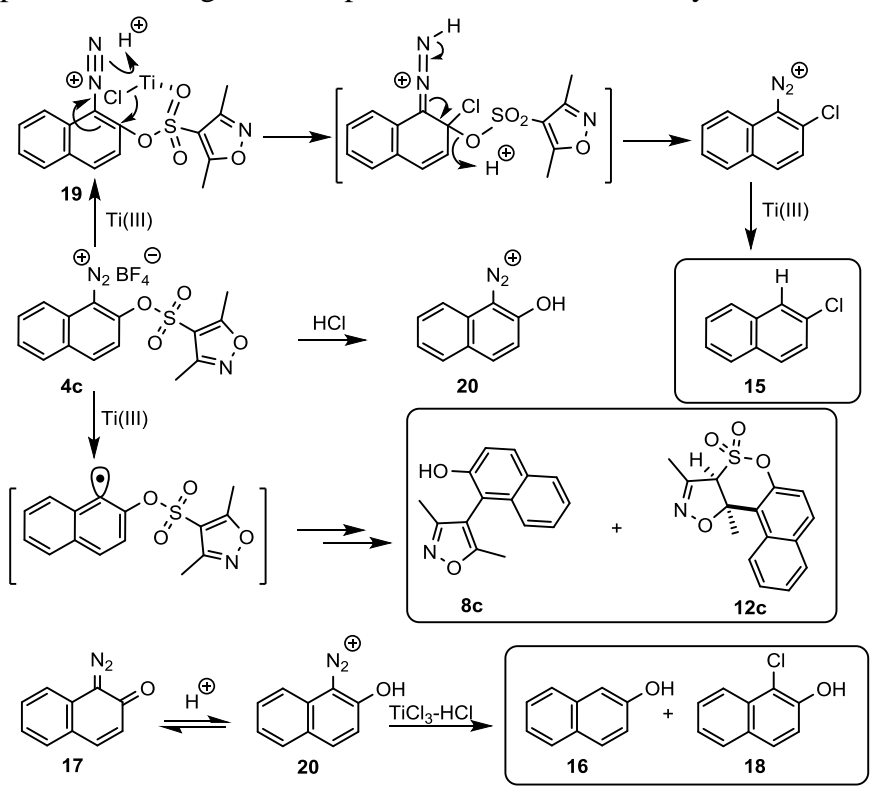

Scheme 9: Reaction pathways involving 4c.

salts bearing nucleofugal groups at the ortho- and para-positions with nuecleophilic species present in the reaction medium. In this instance we posit that reaction between $4 \mathbf{c}$ with $\mathrm{TiCl}_{3}-\mathrm{HCl}$ 
proceeds via an addition elimination reaction, plausibly by way of a complex such as $\mathbf{1 9}$, Scheme $9 .{ }^{29}$ In addition, the conversion of 17 into 16 and 18 presumably proceeds via initial, reversible, protonation $^{30}$ to the diazonium salt $\mathbf{2 0}$ which on further reaction with $\mathrm{TiCl}_{3}-\mathrm{HCl}$ leads to the isolation of $\mathbf{1 6}$ and $\mathbf{1 8}$, Scheme 9 .

In a further set of blank experiments it was decided to study the fate of the diazonium salt $\mathbf{4 e}$ under our standard reaction conditions with a view to determining the efficiency of the halogen transfer process in a substrate that was unable to participate in an intramolecular Truce-Smiles rearrangement. In the event, reaction of $4 \mathbf{e}$ with $\mathrm{TiCl}_{3}-\mathrm{HCl}$ resulted in the isolation of the reduced species 10b (identical to that also generated in Scheme 6) as the major product $(85 \%)$, together with minor amounts of the chlorinated aromatic $21(15 \%)$. The structure assigned to $\mathbf{2 1}$ was also subsequently confirmed by way of single crystal X-ray structure determination, and presumably arose via the intermediacy of the cation 22, Scheme 10. Overall, this outcome infers that $\mathrm{H}$-abstraction from solvent by $\mathbf{6 e}$, affording $\mathbf{1 0 b}$, proceeds at a faster rate than incorporation of halogen.

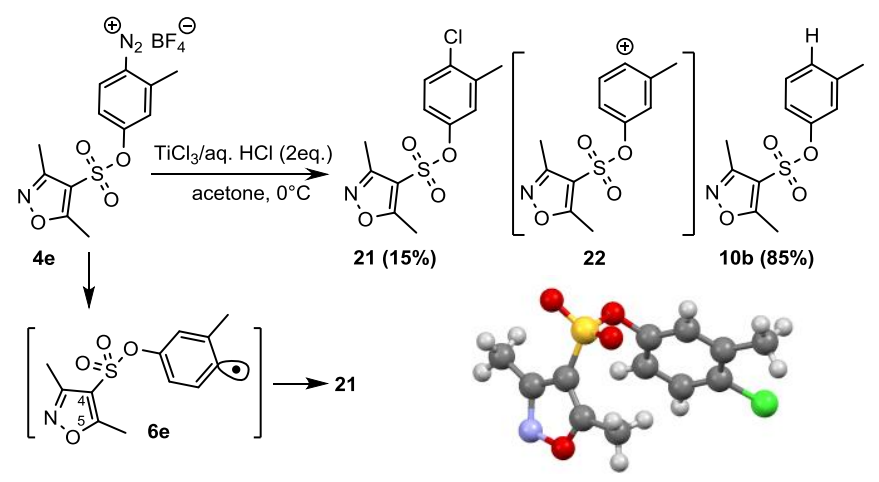

Scheme 10: Reaction of $4 \mathbf{e}$ with $\mathrm{Ti}(\mathrm{III})$ together with the $\mathrm{X}$-ray structure of 21.

\subsubsection{Pathway D: H-atom abstraction from the reaction medium}

As noted with $\mathbf{4 a}$ (Scheme 4) and $\mathbf{4 e}$ (Scheme 10) a common

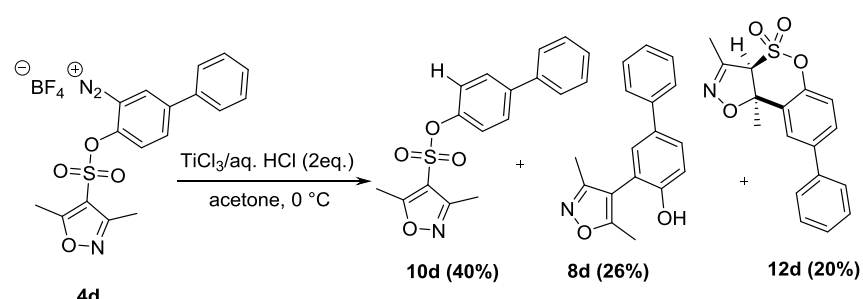

$4 d$
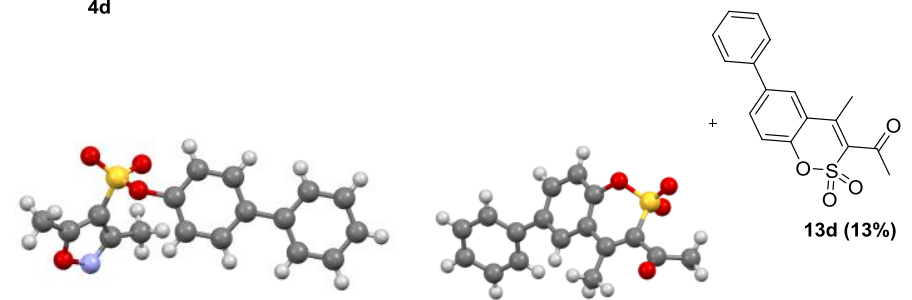

Scheme 11: Assessment of the reactivity profile of $\mathbf{4 d}$ towards Ti(III) together with the X-ray structure of $\mathbf{1 0 d}$ and $\mathbf{1 3 d}$.

side-reaction observed during these Ti(III)-mediated rearrangement reactions is one of $\mathrm{H}$-atom abstraction, where the hydrogen atom is presumed to be derived from the co-solvent, acetone. ${ }^{17,18}$ In certain cases, as with $\mathbf{4 e}$, the hydrogen abstraction pathway leading to $\mathbf{1 0 b}$ ( $85 \%$ yield) becomes the major pathway, Scheme 10. Similarly reaction of $\mathbf{4 d}$ with $\mathrm{TiCl}_{3}-\mathrm{HCl}$ resulted in the isolation of 10d in $40 \%$ yield, together with lesser quantities of the rearranged product $\mathbf{8 d}(26 \%)$, the oxathiin 12d $(20 \%)$ and its hydrolysis product, sultone 13d, in $13 \%$ yield, Scheme 11.

While the degree of $\mathrm{H}$-abstraction vs rearrangement in these reactions was found to be dependent, to some degree, on steric effects (e.g. 4a [3:1] vs $\mathbf{4 b}$ [1:3.7]) the rate of addition of $\mathrm{TiCl}_{3^{-}}$ $\mathrm{HCl}$ to the substrate also appeared to be critical in this regard. In the case of substrate $\mathbf{4 b}$ for example, the rapid addition of $\mathrm{TiCl}_{3}$ $\mathrm{HCl}$ (over 3 minutes when compared to 15 minutes) resulted in an increase in the yield of $\mathbf{1 0 b}$ from $18 \%$ to $42 \%$, an outcome which was at the expense in the yield of $\mathbf{8 b}$, which depreciated from $68 \%$ to $44 \%$. Similar effects have been reported by Heinrich et al. where reaction of diazonium salts with $\mathrm{TiCl}_{3}-\mathrm{HCl}$ resulted in the isolation of reduction products during the intermolecular capture of aryl radicals with trapping agents such as furan. ${ }^{31}$ These outcomes may infer that the H-transfer is in fact derived from water that is coordinated to the titanium centre, ${ }^{32}$ an issue that we have briefly examined. In this case we observe that repeating the reaction between $4 \mathbf{e}$ with $\mathrm{TiCl}_{3}-\mathrm{HCl}$ in acetone- $d_{6}$ as solvent resulted in the generation of a 50:50 mixture of $\mathbf{1 0 b}$ and the deuterated analogue $\mathbf{1 0 b ^ { \prime }}$ as the major products as judged by and anlysis of the ${ }^{1} \mathrm{H}$ NMR spectrum of the crude reaction mixture (Scheme 12.). This outcome indicates that abstraction of $\mathrm{H}(\mathrm{D})$ from solvent by $\mathbf{6 e}$ is partially operative in this case.

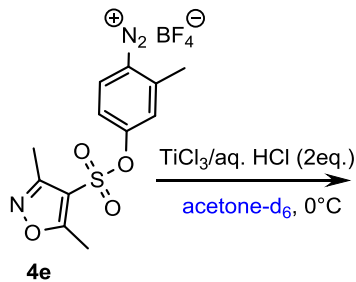

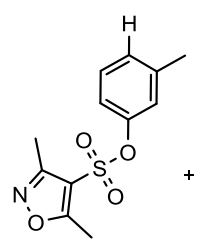

$10 \mathrm{~b}$

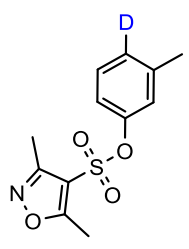

$10 b^{\prime}$

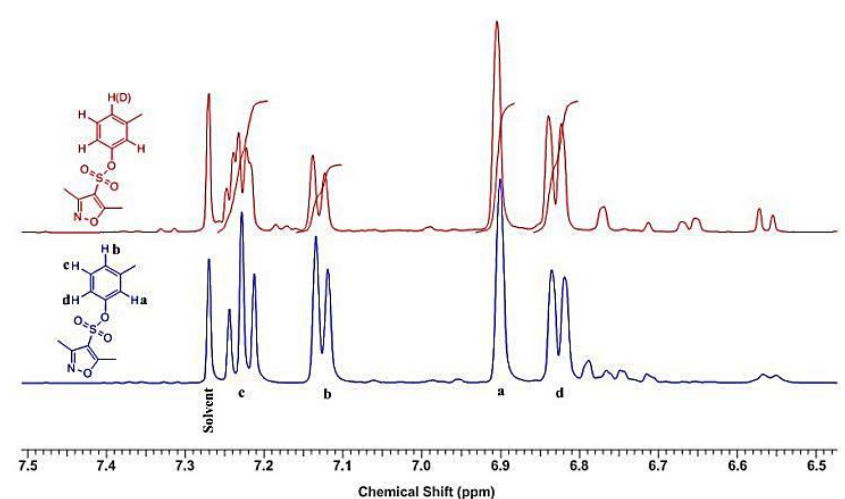

Scheme 12: Reaction of $4 \mathbf{e}$ with $\mathrm{TiCl} 3-\mathrm{HCl}$ in acetone- $d_{6}$ (upper); expansion of the aromatic region of ${ }^{1} \mathrm{H}$ NMR spectra for $\mathbf{1 0 b}$ and 10b' (lower).

\subsubsection{Pathway E: [1,6]-addition reactions}

In addition to the desired ipso-substitution process (Scheme 3 , pathway A), which results in bi-aryl formation, we also noted that aryl radicals 6 also undergo "[1,6]-addition" at $C_{5}$ of the isoxaole ring (Scheme 3, pathway E) leading to the isolation of oxathiins 12a, 15\%, 12b, 2\%, 12c, $8 \%$ and 12d, $20 \%$ (Schemes $4,5,7$ and 11 respectively). ${ }^{33}$ The identity of these $1-6$ addition by-products is readily apparent from an examination of their ${ }^{1} \mathrm{H}$ NMR spectra (Figure 4), where $\mathrm{H}_{4}$ appears as a characteristic, broadened, multiplet at $\delta 4.5-4.65 \mathrm{ppm}$ which exhibit long range coupling $(J \approx 1 \mathrm{~Hz})$ with the methyl group at $\mathrm{C}_{5}(\delta 2.2-2.3 \mathrm{ppm})$. These "[1,6]-addition" reactions proceed regioselectively by intramolecular attack of the aryl radical $\mathbf{6}$ at $\mathrm{C}_{5}$ of the isoxazole ring; the formation of alternate, regioisomeric, products arising 
from attack at $\mathrm{C}_{3}$ were not observed. ${ }^{34}$ We presume that the overall stereochemical outcome of these reactions results from the approach of the $\mathrm{H}$-donor, $\mathrm{R}^{\prime}-\mathrm{H}$, from the less hindered, exoface, of the intermediate radical $\mathbf{2 3}$ (Scheme 12). In addition to the isolation of 12a-d we also observed the formation of sultones 13a $(14 \%)$ and 13d (13\%), Schemes 4 and 11 respectively. Once again structural assignments were initially based on spectroscopic data $\left(\bar{v}_{\max } 1691 \mathrm{~cm}^{-1} ; \delta\left[{ }^{13} \mathrm{C} \mathrm{NMR}\right] 192 \mathrm{ppm}\right)$ and were confirmed by way of single crystal X-ray analysis for both of these compounds. The formation of $13 \mathbf{a}$ and $13 \mathbf{d}$ presumably arises (Scheme 13) via initial reductive cleavage ${ }^{35}$ of the $\mathrm{N}-\mathrm{O}$ bond in isoxazolines $\mathbf{1 2 a}$ and $\mathbf{1 2 d}$ by $\mathrm{Ti}(\mathrm{III})$, followed by hydrolysis of the resultant $\beta$-hydroxy imine $\mathbf{2 4}$ and finally elimination of water. ${ }^{36}$
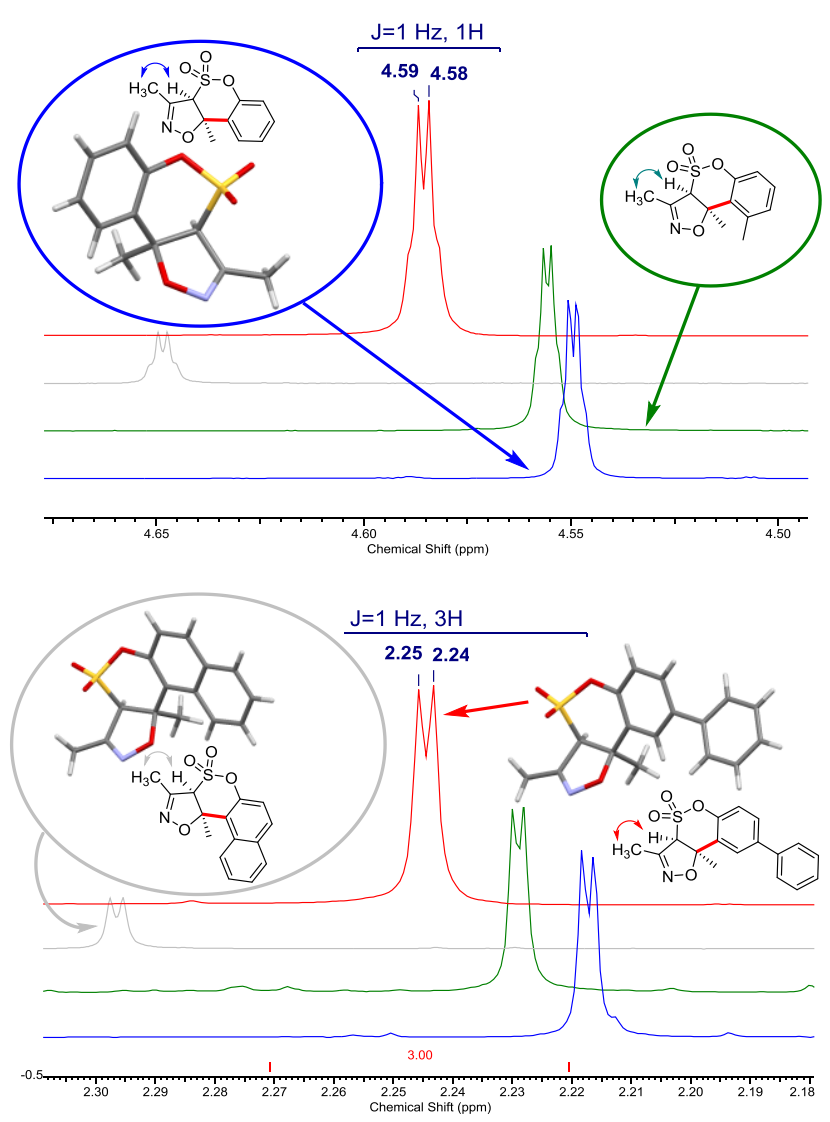

Figure 5: Characteristic ${ }^{1} \mathrm{H}$ NMR spectral data for 12a - 12d.
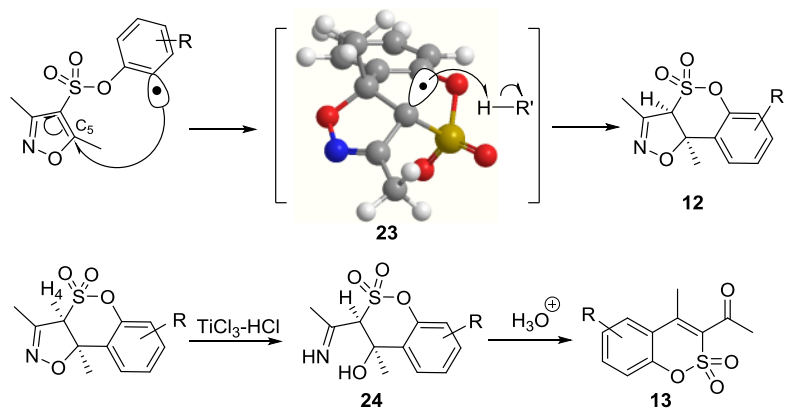

Scheme 13: Generation of $\mathbf{1 2}$ and $\mathbf{1 3}$ via a "[1,6]-addition" process.

\subsubsection{Inter-intramolecular competition experiments}

Given that there is scant information in the literature concerning the addition of free radicals to isoxazoles ${ }^{34}$ we wished to gauge the relative reactivity of the isoxazole nucleus towards aryl radicals. Hence the relative reactivity of aryl radicals 6 towards intramolecular capture was compared to that of a reaction whose absolute rate had been previously determined. Furan, being an electron rich aromatic, is known to react efficiently with electron deficient aryl radicals at a rate $(k=\sim 2.7$ $\mathrm{x} 10^{6} \mathrm{M}^{-1} \mathrm{~s}^{-1}$ ) which is intermediate to that observed for the same reaction with benzene $\left(k=\sim 4.5 \times 10^{5} \mathrm{M}^{-1} \mathrm{~s}^{-1}\right)$ and simple alkenes $\left(k=\sim 2.8 \times 10^{8} \mathrm{M}^{-1} \mathrm{~s}^{-1}\right)$ at $25{ }^{\circ} \mathrm{C}^{37}$ and was therefore chosen as a reference point.

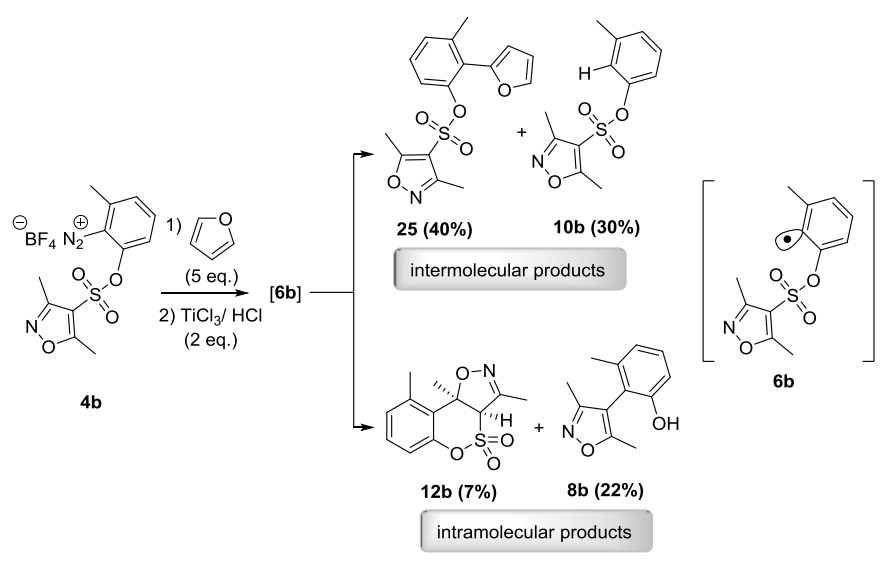

Scheme 14: Inter- vs intramolecular arylation of $6 \mathbf{b}$

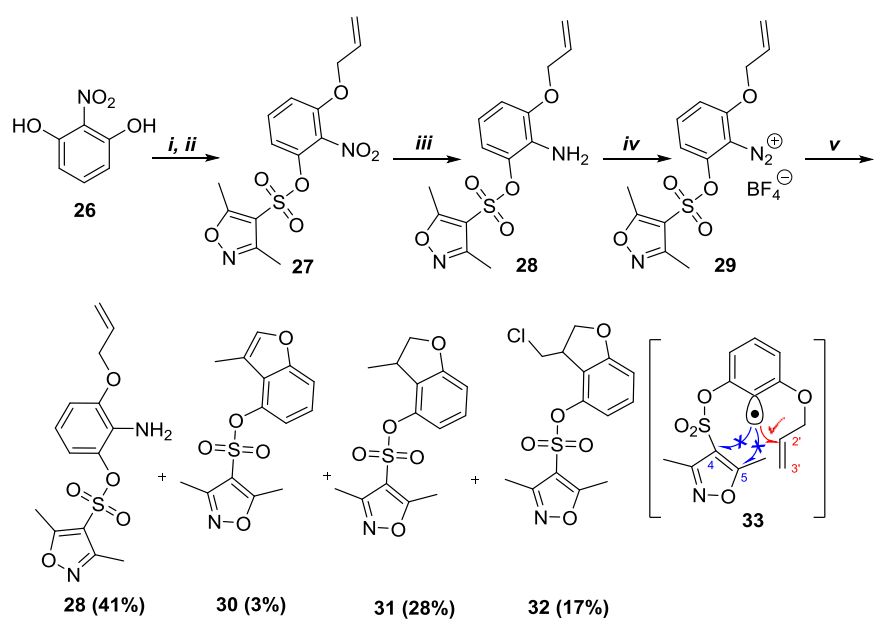

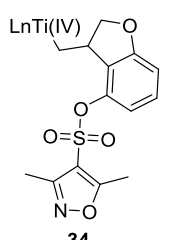<smiles></smiles>

Scheme 15: Radical-clock reactions involving 29. Reagents and conditions: $i \mathrm{~K}_{2} \mathrm{CO}_{3}$ (1 eq.); $\mathrm{CH}_{3} \mathrm{CN} ; 70{ }^{\circ} \mathrm{C} ; 57 \%$; $i$ $\mathrm{Et} 3 \mathrm{~N}$ (1.1 eq.); 1 (1.1 eq.); $\mathrm{CH}_{2} \mathrm{Cl}_{2} ; 0$ ${ }^{\circ} \mathrm{C}$; ca. $100 \%$; iii $\mathrm{Zn}$ dust (5 eq.); $\mathrm{NH}_{4} \mathrm{Cl}$; $\mathrm{MeOH} / \mathrm{THF} ; 98 \%$; iv $\mathrm{HBF}_{4}(2.5$ eq.); iso-amyl nitrite (1.1 eq.); $\mathrm{EtOH} ; 95 \% ; v \mathrm{TiCl}_{3}-\mathrm{HCl}$ (2 eq.); acetone; 0 ${ }^{\circ} \mathrm{C}$.

In an initial competition experiment the diazonium salt $\mathbf{4 b}$ was reacted with $\mathrm{TiCl}_{3}(2 \mathrm{eq})$ in the presence of an excess of furan (5 eq.), under our standard reaction conditions. Purification of the products from this reaction by column chromatography and then preparative HPLC afforded the substituted furan 25 (40\%), the result of an intermolecular addition of aryl radical $\mathbf{6 b}$ to furan, together with $\mathbf{8 b}(22 \%)$ and $\mathbf{1 2 b}(7 \%)$ via intramoleluar isoxazole addition, and the reduced product $\mathbf{1 0 b}(30 \%)$, Scheme 14 . These results clearly demonstrate that the hindered aryl radical $\mathbf{6 b}$ competes effectively for furan, in an intermolecular process, 
when compared to the alternate, intramolecular addition reaction, suggesting that the isoxazole moiety of $\mathbf{4 b}$ is less reactive towards radical attack than the unsubstituted furan nucleus.

As an extension to this study the synthesis of diazonium salt 29 was also accomplished from bis-phenol 26 using well established chemistry (Scheme 15). Here an allylloxy-residue, situated ortho- to the incipient aryl radical centre, was to be used as an internal radical clock $^{38 a}$ enabling an estimation of the efficiency of addition to the isoxazole ring versus reaction with the alkene moiety. ${ }^{\dagger}$ In the event, exposure of 29 to $\mathrm{TiCl}_{3}-\mathrm{HCl}$, as described previously, generated a complex reaction mixture which was purified by preparative HPLC (Scheme 15).

Surprisingly, the single largest component of this reaction was one of non-productive reduction resulting in the isolation of the aniline 28 (41\%) together with the benzofuran 30 (3\%), dihydrobenzofuran 31 (28\%) and chloride 32 (17\%), Scheme 15. All three of the latter products are the result of a 5-exo-trigaddition of the aryl radical 33 to the $\mathrm{C}^{\prime}$ - $\mathrm{C}^{\prime}$ double bond of the allyl ether moiety, a process that is evidently more favourable than attack at $\mathrm{C} 4$ - or C5- of the isoxazole ring. It is not clear, at this stage, whether the final, isolated, products, 30-32, arises from the intermediacy of a discrete $\mathrm{Ti}(\mathrm{IV})$ complex $\mathbf{3 4}$, or free radical intermediate $\mathbf{3 5}{ }^{39}$

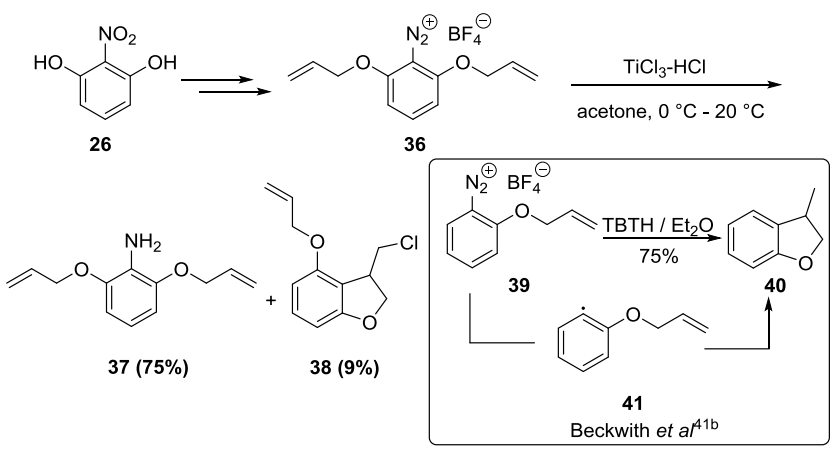

Scheme 16: Attempted cyclization using $\mathbf{3 6}$ as starting material.

In order to gauge the efficiency of 5-exo-trig-cyclization reactions in this system the synthesis of the 2,6bis(allyloxy)benzenediazonium salt 36, which is devoid of an isoxazole appendage, was undertaken and its reaction with Ti(III) was investigated, Scheme 16. Somewhat unexpectedly, exposure of 36 to $\mathrm{TiCl}_{3}-\mathrm{HCl}$ afforded the aniline $\mathbf{3 7}$ in high yield (75\%) together with the dihydrobenzofuran $\mathbf{3 8}$ as a minor by-product $(9 \%){ }^{40,41 a}$ Clearly, the introduction of functionality, which may exert either a steric or electronic effect, ortho- to the diazonium moiety, has a major influence on the outcome of the initial electron transfer reaction which precedes aryl radical formation. These results are also in stark contrast to the chemistry of the diazonium salt 39, which is known to undergo cyclization to the dihydrobenzofuran $\mathbf{4 0}$ in good yield when conducted under reaction conditions that promote the generation of aryl radicals such as $\mathbf{4 1}$. $^{41 \mathrm{~b}}$

\subsubsection{Effect of metal on product distribution}

We previously noted the effect of changing the reductant $\left(\mathrm{Cu}\left(\mathrm{NO}_{3}\right)_{2}-\mathrm{Cu}_{2} \mathrm{O}^{26}\right.$ instead of $\left.\mathrm{TiCl}_{3}-\mathrm{HCl}\right)$ on the outcome of the rearrangement reactions of $\mathbf{4 c}$ (see Scheme 8) and wished to investigate these effects further. The outcome of the reaction between $\mathbf{4 a}, \mathbf{4} \mathbf{b}$ or $\mathbf{4 e}$ with $\left(\mathrm{Cu}\left(\mathrm{NO}_{3}\right)_{2}-\mathrm{Cu}_{2} \mathrm{O}\right.$ was found to be

$\uparrow$ Cyclization of aryl radicals, such as $\mathbf{3 9}$ to $\mathbf{4 0}$, via a 5-exo-trig-pathway (Scheme 16) is known to proceed rapidly ${ }^{38 b}\left(k \approx 6.3 \times 10^{9} \mathrm{~s}^{-1}\right.$ at $\left.30{ }^{\circ} \mathrm{C}\right)$. substrate dependent but largely mirrored the results obtained using $\mathrm{TiCl}_{3}-\mathrm{HCl}$ although the isolation of products arising from hydroxydediazoniation, as expected, ${ }^{26}$ now become apparent, Scheme 16.

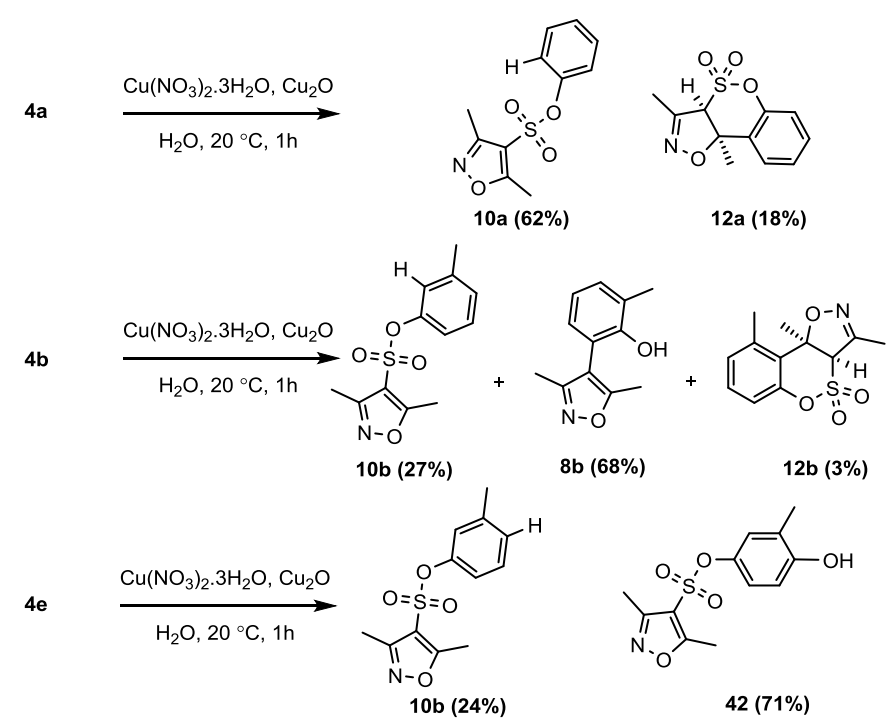

Scheme 17: Effect of metal additives on the radical Truce-Smiles rearrangement.

In a control experiment reaction of $4 \mathbf{e}$ with $\mathrm{Cu}\left(\mathrm{NO}_{3}\right)_{2}-\mathrm{Cu}_{2} \mathrm{O}$ afforded, as expected, phenol $\mathbf{4 2}$ as the major product $(71 \%)$ together with the ester $\mathbf{1 0 b}(24 \%)$, Scheme 17 . This outcome is to be compared with that from the reaction of $\mathbf{4 e}$ with $\mathrm{TiCl}_{3}-\mathrm{HCl}$ which afforded $\mathbf{1 0 b}$ as the major product $(85 \%)$ together with relatively minor quantities of the chloro-compound 21 (15\%). Encouragingly, rearrangement of $\mathbf{4 b}$ in the presence of $\left(\mathrm{Cu}\left(\mathrm{NO}_{3}\right)_{2}-\mathrm{Cu}_{2} \mathrm{O}\right.$ led to $\mathbf{8 b}$ in $68 \%$ yield, together with $\mathbf{1 0 b}$ $(27 \%)$ and $\mathbf{1 2 b}(3 \%)$ rather than to hydroxylation products, which indicates that radical formation and subseqent capture is faster than hydroxyl incorporation in this instance.

\subsubsection{Comparison with related methodology: attempted fluoride- promoted Truce-Smiles reactions}

We recently reported ${ }^{42}$ a fluoride induced Truce-Smiles rearrangement of ortho-(trimethylsilyl)aryl sulphonate esters leading to bi-aryls and wondered whether this particular process could be applied to the synthesis of functionalized isoxazoles, Scheme 17. Unfortunately all attempts to induce rearrangement of 42 into 8a, using a range of fluoride sources, under various conditions, met with failure. For example, reaction of $\mathbf{4 3}$ with TBAF in THF-acetonitrile merely promoted protodesilylation and resulted in the isolation of the ester 10a (78\%). Alternatively, reaction of $\mathbf{4 2}$ with cesium fluoride in THF led to the isolation of phenol, $\mathbf{4 5}$ in $92 \%$ yield, Scheme 18. Evidently

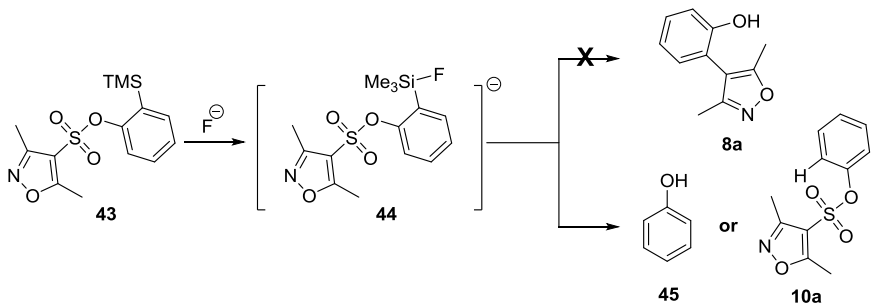

Scheme 18: Attempted fluoride-mediated, "anionic-", Truce-Smiles rearrangement reaction of $\mathbf{4 3}$.

the hypervalent silicon species $\mathbf{4 4}$, the presumed intermediate in these protodesilylation reactions, is either insufficiently reactive or too sterically encumbered to participate in either ipsosubstitution or addition reactions with the isoxazole template. 
This outcome underscores the differing electronic and steric demands of the radical Truce-Smiles rearrangements when compared to its anionic variant, subtleties which are currently the focus of further investigation.

\section{Conclusion}

A detailed analysis of the product distribution resulting from $\mathrm{TiCl}_{3}-\mathrm{HCl}$ - promoted, radical, Truce Smiles rearrangements of functionalized diazonium salts is reported. The intended outcome from these reactions - the preparation of isoxazoles substituted at $\mathrm{C}_{4^{-}}$with aromatic residues - was only partially accomplished, because the desired rearrangement reaction (via an ipso-substitution mechanism) is highly dependent on structural features within the substrate and the nature of the radical promoter. That said it would appear that this methodology may find application in the synthesis of bi-aryls which are sterically congested about the newly formed bi-aryl axis. As such our observations are in keeping with Motherwell's "enforced orthogonality" concept. In certain cases ipso-substitution is also accompanied by addition, and subsequent fragmentation of the isoxazoline ring resulting in the isolation of a variety of oxathiins and sultones. The isolation of reduction products and chloroaromatics are also observed in a number of these reactions. We have shown, using "radical clock" reactions, that the isoxazole nucleus is less reactive than furan towards radical addition. The course of the initial diazonium salt reduction by $\mathrm{Ti}(\mathrm{III})$ is also heavily influenced by neighbouring functionality: in certain cases a previously unreported reduction of diazonium salts to anilines, rather than to aryl radicals, becomes the major reaction pathway. These radical Truce-Smiles rearrangements are also promoted by other reducatns such as $\mathrm{Cu}\left(\mathrm{NO}_{3}\right)_{2}-\mathrm{Cu}_{2} \mathrm{O}$ and efforts are currently underway in order to define agents which promote cyclization without the intervention competing side reactions. Anionic variants ${ }^{42}$ of the Truce-Smiles rearrangements were unsuccessful when using an isoixazole nucleus as acceptor.

\section{Experimental section}

\subsection{General Experimental}

All air-sensitive reactions were carried out under an atmosphere of nitrogen in oven-dried glassware unless stated otherwise. All reagents were used as received from commercial sources commercially unless stated otherwise. Infrared spectra were recorded using a Bruker-Alpha- FT-IR spectrometer. Reactions were monitored by thin layer chromatography (TLC) on $0.25 \mathrm{~mm}$ pre-coated plastic sheets Merck silica gel $60 \mathrm{~F}_{254}$ polyester backed plates. Visualization of TLC plates was achieved by either viewing under a UV lamp $\left(\lambda_{\max } 254 \mathrm{~nm}\right)$ or by thermal development after dipping into an aqueous solution of potassium permanganate. Column chromatography was conducted on Merck silica gel SDS (particle size $40-63 \mu \mathrm{m}$ ) as the stationary phase. HPLC separations were conducted on an Agilent 1260A preb HPLC. Melting points were recorded on a Gallenkamp melting point apparatus and are uncorrected. ${ }^{1} \mathrm{H}$ NMR, ${ }^{13} \mathrm{C}$ NMR, ${ }^{13} \mathrm{C}$ DEPT90, ${ }^{13} \mathrm{C}$ DEPT135, ${ }^{13} \mathrm{C}$ DEPTQ and COSY spectra were recorded on Bruker-DRX $300 \mathrm{MHz}$, Bruker-B12-400 ultrashield/ Avance III 400 (BBO $400 \mathrm{MHz}$ S15mm), Bruker-B14-Ascend $500 \mathrm{MHz} /$ Avance III HD (CPPBBO 5mm), Bruker-B11-Avance III HD/Ascend $400 \mathrm{MHz}$ (CPPBBO $5 \mathrm{~mm}$ ), Bruker-B11-Avance II 500 / 500 Ultrashield (BBO $500 \mathrm{MHz}$ S2 5mm), Bruker-B07 DRX Avance 500 / 500 Ultrashield (BBI $500 \mathrm{MHz}$ SB 5mm) spectrometers operating at ambient temperature. Chemical shifts values are given in parts per million (ppm); peak patterns are indicated as follows: br.s, broad singlet; s, singlet; d, doublet; t, triplet; q, quadruplet; qui, quintuplet; m, multiplet. DEPTQ refer to ${ }^{13} \mathrm{CNMR}$ signal, while signals were separated as $\left(\mathrm{CH}, \mathrm{CH}_{3}\right.$ "up") and $\left(\mathrm{C}_{\text {qua. }}, \mathrm{CH}_{2}\right.$ "down"). NMR assignments were made with the aid of DEPT135, DEPT90, COSY pulse sequences. Low resolution mass (LRMS) and high resolution (HRMS) spectra were recorded on a Waters SQD2 and Waters Q-TOF micro mass spectrometers respectively. All mass spectrometry results are reported in the form $\mathrm{m} / \mathrm{z}$. Elemental analysis was performed by Mr. Ian Jennings in the Microanalytical Laboratory within the School of Chemistry, The University of Manchester. X-ray crystallographic data for selected compounds was recorded in the X-ray Crystallography Laboratory, School of Chemistry, University of Manchester (Supplementary information)

\subsection{General Synthetic Procedures (GP)}

\subsubsection{Synthesis of Radical precursors}

\subsubsection{General Procedure 1 (GP1): Sulfonate esters using aqueous $\mathrm{NaOH}$ as base}

In a $100 \mathrm{~mL}$ round bottom flask with proper magnetic stirrer, a mixture of the phenol (1.1 eq.) 3,5-dimethylisoxazole-4-sulfonyl chloride $\mathbf{1}$ (1 eq.), in $\mathrm{CH}_{2} \mathrm{Cl}_{2}(50 \mathrm{~mL})$ was stirred vigorously for 5 minutes. To this stirred solution, excess of aqueous $\mathrm{NaOH}$ solution (2M, $8 \mathrm{~mL})$ was added, followed by addition of water (2-3 mL) and allowed to stir for $24 \mathrm{~h}$. The reaction mixture was transferred to separatory funnel by (water, $5 \mathrm{~mL}$ ) and extracted by $\mathrm{CH}_{2} \mathrm{Cl}_{2}(3 \times 30 \mathrm{~mL})$. The combined organic phase was dried by $\mathrm{MgSO}_{4}$, and the solvent was removed in vacuo. The isolated products were almost pure otherwise purified by recrystallization or column chromatography.

\subsubsection{General Procedure 2 (GP2): Sulfonate ester using $\mathrm{Et}_{3} \mathrm{~N}$ as base}

To an ice-cold solution of the phenol (1.1 eq.), triethylamine(1.1 eq.), $\mathrm{CH}_{2} \mathrm{Cl}_{2}$ (75 ml) under an $\mathrm{N}_{2}$ atmosphere, a solution of 3,5dimethylisoxazole-4-sulfonyl chloride $\mathbf{1}$ (1.1 eq.) in $10 \mathrm{ml} \mathrm{CH}_{2} \mathrm{Cl}_{2}$ was added dropwise. The reaction mixture was allowed to warm to room temperature and stirred for $24 \mathrm{~h}$. The reaction mixture was quenched with water and the $\mathrm{CH}_{2} \mathrm{Cl}_{2}$ layer was separated, dried over $\mathrm{MgSO}_{4}$ and concentrated in vacuo. The crude was purified by flash column chromatography using $\mathrm{CH}_{2} \mathrm{Cl}_{2}$ to afford pure sulfonate esters or sulfonamides.

\subsubsection{General Procedure 3 (GP3): Synthesis of Diazonium Salts}

A slurry of aniline 3(a-e) (1 eq.) in ethanol (5 mL) was stirred for $5 \mathrm{~min}$. To this stirred solution at $0{ }^{\circ} \mathrm{C}$, aqueous solution of $\mathrm{HBF}_{4}$ $(48 \%, 2.6$ eq.) was added and followed by dropwise addition of isoamyl nitrite(1.2 eq.) over $15 \mathrm{~min}$. The resulting reaction mixture was stirred for $30 \mathrm{~min}$. at temperature $0-5{ }^{\circ} \mathrm{C}$ and then allowed to stir at room temperature for $30 \mathrm{~min}$. The precipitated product was carefully filtrated and washed with a small amount of the ethanol. The crude diazonium product was dried at room temperature and purified by dissolving it in minimum amount of acetone followed by precipitation by dropwise addition of cold diethyl ether.

\subsubsection{General Procedure 4 (GP4): $\mathrm{TiCl}_{3}$ Reactions}

A solution of aqueous $\mathrm{TiCl}_{3}(1.29 \mathrm{M}$ in $\mathrm{HCl}, 2$ eq. $)$ was added dropwise to a solution of diazonium salt (1eq.) in acetone (3-5 $\mathrm{mL})$ in sealed vial and under $\left(\mathrm{N}_{2}\right)$ atmosphere at $0{ }^{\circ} \mathrm{C}$. After the addition, the reaction mixture was stirred for $0.5 \mathrm{~h}$ at $0{ }^{\circ} \mathrm{C}$ and then $1 \mathrm{~h}$ at RT, water was added and it was extracted with $\mathrm{CH}_{2} \mathrm{Cl}_{2}$. The organic layer was washed with brine, dried over $\mathrm{MgSO}_{4}$ and evaporated in vacuo to afford various products. The crude 
products were purified by column chromatography on silica gel or by Preparative-HPLC.

\subsubsection{General Procedure 5 (GP5): Allylation of phenols}

To an oven-dried $100 \mathrm{~mL}$ round flask containing 2nitroresorcinol (2 eq.) and $\mathrm{K}_{2} \mathrm{CO}_{3}$ (2.0 eq.) in $\mathrm{CH}_{3} \mathrm{CN}$, allyl bromide (1.1 eq.) was added and the reaction mixture was stirred for $24 \mathrm{~h}$ at $70{ }^{\circ} \mathrm{C}$. After completion the reaction mixture was cooled to room temperature, diluted with water and extracted with DCM. The combined organic layers were dried over $\mathrm{MgSO}_{4}$ and purified by flash chromatography on silica gel

\subsubsection{General Procedure 6 (GP6): Reduction of nitro group} to anilines

Nitro compound (1 eq.) and zinc dust (5 eq.) were suspended in mixed solvent of (MeOH: THF, 1:1; v/v) and an excess of saturated $\mathrm{NH}_{4} \mathrm{Cl}$ solution was added carefully. The reaction mixture became warm. There was an obvious change in the zinc suspension. The reaction was finished in 10 minutes. The reaction mixture was filtered through a silica plug and diluted with EtOAc and saturated $\mathrm{NaHCO}_{3}$. The layers were separated and the combined organics dried over $\mathrm{MgSO}_{4}$ and concentrated under reduced pressure.

\subsubsection{General Procedure 7 (GP7): TBAF-promoted rearrangements reactions}

Under nitrogen atmosphere, (TBAF, 3 eq.) was added slowly to a stirred solution of 2-(trimethylsilyl)phenyl 3,5dimethylisoxazole-4-sulfonate 49 (1 eq.) in dry solvent $\left(\mathrm{CH}_{3} \mathrm{CN} /\right.$ THF, $1 \mathrm{M})$. The reaction mixture was stirred at $\left(\mathrm{RT} / 70{ }^{\circ} \mathrm{C}\right)$ for sixteen hours and then poured into ether $(25 \mathrm{~mL})$. The resulting mixture was washed with dilute $\mathrm{HCl}(3 \mathrm{M}, 10 \mathrm{~mL})$ and then with water $(2 \times 10 \mathrm{~mL})$, dried over $\mathrm{MgSO}_{4}$ and the reaction mixture taken to dryness in vacuo. The crude product was purified by column chromatography.

\subsubsection{General Procedure 8 (GP8): CsF-promoted rearrangement reactions}

To an oven-dried $25 \mathrm{~mL}$ round-bottom flask equipped with a magnetic stir bar was added $\mathrm{CsF}$ ( 3 eq.). The reaction flask was connected to an oven-dried condenser and sealed well with proper rubber septum. A balloon was linked on top, evacuated and backfilled with $\mathrm{N}_{2}$ gas (three times). $10 \mathrm{~mL}$ of solution $(0.1$ M) aryl anion precursor 49 (1eq.) in dry (THF / MeCN) was added to the CsF. The resulting mixture was stirred in (RT / 70 $\left.{ }^{\circ} \mathrm{C}\right)$ for $16 \mathrm{~h}$ and then poured into ether $(20 \mathrm{~mL})$. The mixture was washed with dilute $\mathrm{HCl}(3 \mathrm{M}, 10 \mathrm{~mL})$ and with water $(2 \times 10$ $\mathrm{mL}$ ). Dried over $\mathrm{MgSO}_{4}$ and the crude was taken to dryness in vacuo. The crude product was purified by flash column chromatography.

\subsubsection{General Procedure 9 (GP9): Effect of Metal $\left(\mathrm{Cu}\left(\mathrm{NO}_{3}\right)_{2} .3 \mathrm{H}_{2} \mathrm{O}-\mathrm{Cu}_{2} \mathrm{O}\right)^{26}$}

4(a-e) (1 eq.) was added to a solution of copper (II) nitrate trihydrate (57 eq.) and copper (I) oxide (3 eq.) in water (108 mL/ $\mathrm{mmol})$, the reaction mixture was vigorously stirred at room temperature for $70 \mathrm{~min}$. The solid was filtered and washed with dichloromethane. The filtrate was extracted three times with dichloromethane, dried over anhydrous magnesium sulfate, filtered, and concentrated under reduced pressure. The crude was purified on silica gel column chromatography (2:8 ethyl acetate: petroleum ether; $\mathrm{v} / \mathrm{v}$ )

\subsection{Syntheses of sulfonate esters}

\subsubsection{2-Aminophenyl 3',5'-dimethylisoxazole-4'-sulfonate, $3 a$}

Using GP1: Starting with 3,5-dimethylisoxazole-4-sulfonyl chloride 1 ( 2 g, 10.22 mmol, 1 eq.), 2-amino phenol 2a (1.22 g, 11.24 mmol, 1.1 eq.), $\mathrm{NaOH}(2 \mathrm{M}, 25 \mathrm{~mL}, 50 \mathrm{mmol})$. Recrystallization by petroleum ether gave the title compound as a brown-coloured crystalline solid. Yield $2.03 \mathrm{~g}(74 \%)$.

Using GP2: Starting with 3,5-dimethylisoxazole-4-sulfonyl chloride 1 ( 1 g, $5.11 \mathrm{mmol}, 1.1$ eq.), 2-amino phenol 2a (506.3 $\mathrm{mg}, 4.64 \mathrm{mmol}, 1$ eq.), $\mathrm{Et}_{3} \mathrm{~N}$ (0.712 mL, $5.11 \mathrm{mmol}, 1.1$ eq.). Yield 1.19 g (96 \%); mp. 99-101 ${ }^{\circ} \mathrm{C} ; \overline{\boldsymbol{v}}_{\max } / \mathbf{c m}^{-1}$ (ATR) 3473, $3386,3075,1623,1587,1502,1436,1377,1161,1362,1314$, 1269, 1205, 1115, 1030, 878, 804, 758, 710. ${ }^{\mathbf{1}} \mathbf{H}$ NMR $(400$ $\left.\mathrm{MHz}, \mathrm{CDCl}_{3}\right) \delta 2.26$ (s, $3 \mathrm{H}$ ), 2.35 (s, $3 \mathrm{H}$ ), 3.79 (br. s., $2 \mathrm{H}$ ), $6.56-6.63(\mathrm{~m}, 1 \mathrm{H}), 6.69(\mathrm{dd}, J=8.0,1.0 \mathrm{~Hz}, 1 \mathrm{H}), 6.80(\mathrm{dd}$, $J=8.0,1.0 \mathrm{~Hz}, 1 \mathrm{H}), 6.98-7.04(\mathrm{~m}, 1 \mathrm{H}) .{ }^{13} \mathbf{C} \mathbf{N M R}(100 \mathrm{MHz}$, $\left.\mathrm{CDCl}_{3}\right) \delta 10.7,12.5,112.3,117.5,118.6,122.9,128.5,136.1$, 139.8, 158.2, 175.7. LRMS (ES $\left.{ }^{+}\right) \mathrm{C}_{11} \mathrm{H}_{12} \mathrm{~N}_{2} \mathrm{O}_{4} \mathrm{~S}$ requires 268; found $\left(\mathbf{E S}^{+}\right) 269[\mathrm{M}+\mathrm{H}]^{+}$, (ES) $267[\mathrm{M}-\mathrm{H}]^{-}$; HRMS $\left(\mathbf{E S}^{+}\right)$ $\mathrm{C}_{11} \mathrm{H}_{12} \mathrm{~N}_{2} \mathrm{O}_{4} \mathrm{SNa}[\mathrm{M}+\mathrm{Na}]^{+}$requires 291.0415; found 291.0425 $(\Delta=3.3 \mathrm{ppm})$. Microanalysis $\mathrm{C}_{11} \mathrm{H}_{12} \mathrm{~N}_{2} \mathrm{O}_{4} \mathrm{~S}$ requires: $\mathrm{C}, 49.25, \mathrm{H}$, 4.51, N, 10.44, S, $11.95 \%$; found: C, 49.45, H, 4.76, N, 10.37, S, $11.78 \%$.

\subsubsection{2-Amino-3-methylphenyl 3',5'-dimethylisoxazole-4- sulfonate, $3 b$}

Using GP1: Starting with 3,5-dimethylisoxazole-4-sulfonyl chloride 1 ( 2 g, 10.22 mmol, 1 eq.), 2-amino-3-methylphenol $\mathbf{2 b}$ (1.38 g, $11.24 \mathrm{mmol}, 1.1$ eq.), $\mathrm{NaOH}(2 \mathrm{M}, 25 \mathrm{~mL}, 50 \mathrm{mmol})$. Recrystallization by petroleum ether gave the title compound as brown-coloured, crystalline solid. Yield $2.2 \mathrm{~g} \mathrm{(77 \% ).}$

Using GP2: Starting with 3,5-dimethylisoxazole-4-sulfonyl chloride 1 ( $1 \mathrm{~g}, 5.11 \mathrm{mmol}, 1.1$ eq.), 2-amino-3-methylphenol $\mathbf{2 b}$ (571.46 mg, 4.64 mmol, 1 eq.), $\mathrm{Et}_{3} \mathrm{~N}$ (0.712 mL, $5.11 \mathrm{mmol}, 1.1$ eq.). Yield $1.3 \mathrm{~g}(98 \%)$; mp. $94-96{ }^{\circ} \mathrm{C} ; \overline{\boldsymbol{v}}_{\max } / \mathbf{~ c m}^{-1}$ (ATR): 3464 , 3381, 3029), 2977, 2941, 2905, 1626, 1584, 1482, 1437, 1405, 1361, 1118, 1268, 1196, 911, 794, 770. ${ }^{1} \mathbf{H}$ NMR $(400 \mathrm{MHz}$, $\left.\mathrm{CDCl}_{3}\right) \delta 2.12$ (s, $3 \mathrm{H}$ ), 2.25 (s, $3 \mathrm{H}$ ), 2.37 (s, $3 \mathrm{H}$ ), 3.63 (br. s., 2 H), $6.59(\mathrm{~d}, J=8.0 \mathrm{~Hz}, 1 \mathrm{H}), 6.66(\mathrm{~d}, J=1.0 \mathrm{~Hz}, 1 \mathrm{H}), 6.82$ (dq, $J=8.0,1.0 \mathrm{~Hz}, 1 \mathrm{H}) .{ }^{13} \mathbf{C}$ NMR $\left(100 \mathrm{MHz}, \mathrm{CDCl}_{3}\right) \delta 10.7,12.5$, $17.3,112.4,117.5,123.2,128.5,129.0,136.1,137.1,158.2$, 175.6. LRMS (ES $\left.{ }^{+}\right) \mathrm{C}_{12} \mathrm{H}_{14} \mathrm{~N}_{2} \mathrm{O}_{4} \mathrm{~S}$ requires 282; found (ES $\left.{ }^{+}\right) 283$ $[\mathrm{M}+\mathrm{H}]^{+}$; HRMS $\left(\mathbf{E S}^{+}\right) \mathrm{C}_{12} \mathrm{H}_{15} \mathrm{~N}_{2} \mathrm{O}_{4} \mathrm{~S}[\mathrm{M}+\mathrm{H}]^{+}$requires 283.0312; found $283.0313(\Delta=0.35 \mathrm{ppm})$.

\subsubsection{Synthesis of $\mathbf{3 c}$}

Using GP1: Starting with 3,5-dimethylisoxazole-4-sulfonyl chloride 1 ( $1 \mathrm{~g}, 5.11 \mathrm{mmol}, 1$ eq.), 1-aminonaphthalen-2-ol hydrochloride 2c (1.1 g, $5.62 \mathrm{mmol}, 1.1$ eq.), $\mathrm{NaOH}(2 \mathrm{M}, 12 \mathrm{~mL}$, $24 \mathrm{mmol}$ ). Recrystallization by $\mathrm{CHCl}_{3} /$ petroleum ether gave title compound as yellow-brown coloured crystalline solid. Yield 1.2 g (72\%); mp. $116-117{ }^{\circ} \mathrm{C} ; \overline{\boldsymbol{v}}_{\max } / \mathbf{c m}^{-1}$ (ATR) 3475, 3391, 3066, 3054, 2958, 2929, 1618, 1590, 1511, 1465, 1438, 1407, 1385, 1363, 1205, 1269, 1179, 1159, 1129, 1112, 1078, 1036, 976, 871, 707. ${ }^{1} \mathbf{H}$ NMR $\left(400 \mathrm{MHz}, \mathrm{CDCl}_{3}\right): \delta 2.24(\mathrm{~s}, 3 \mathrm{H}), 2.28(\mathrm{~s}, 3 \mathrm{H})$, 4.31 (br. s., $2 \mathrm{H}), 6.91$ (d, $J=9.0 \mathrm{~Hz}, 1 \mathrm{H}), 7.08$ (d, $J=9.0 \mathrm{~Hz}, 1$ $\mathrm{H}), 7.35$ - 7.39 (m, $2 \mathrm{H}), 7.63-7.69$ (m, $2 \mathrm{H}) .{ }^{13} \mathbf{C}$ NMR (100 $\left.\mathrm{MHz}, \mathrm{CDCl}_{3}\right): \delta 10.8,12.6,112.6,118.5,120.9,121.2,124.1$, $125.8,126.6,128.6,131.3,132.8,135.1,158.1,175.7$. LRMS $\left(\mathbf{E S}^{+}\right) \mathrm{C}_{15} \mathrm{H}_{14} \mathrm{~N}_{2} \mathrm{O}_{4} \mathrm{~S}$ requires 318 ; found $\left(\mathbf{E S}^{+}\right) 319[\mathrm{M}+\mathrm{H}]^{+}$; HRMS (ES $\left.{ }^{+}\right) \mathrm{C}_{15} \mathrm{H}_{15} \mathrm{~N}_{2} \mathrm{O}_{4} \mathrm{~S}[\mathrm{M}+\mathrm{H}]^{+}$requires 319.0753; found $319.0765(\Delta=3.9 \mathrm{ppm})$.

4.3.4. Synthesis of 3-amino-[1,1'-biphenyl]-4-yl 3',,5'dimethylisoxazole-4' '-sulfonate, $\mathbf{3 d}$

Using GP1: Starting with 3,5-dimethylisoxazole-4-sulfonyl chloride 1 (960.08 mg, $4.90 \mathrm{mmol}, 1$ eq.), 3-amino-[1,1'- 
biphenyl]-4-ol, 2d (1 g, 5.39 mmol, 1.1 eq.), $\mathrm{NaOH}$ (2M, 12 $\mathrm{mL}, 24 \mathrm{mmol})$. Recrystallization by $\mathrm{CH}_{2} \mathrm{Cl}_{2} /$ petroleum ether gave the title compound as feint brown-coloured crystalline solid. Yield $1.04 \mathrm{~g}(62 \%)$.

Using GP2: Starting with 3,5-dimethylisoxazole-4-sulfonyl chloride 1 (1 g, $5.11 \mathrm{mmol}, 1.1$ eq.), 3-amino-[1,1'-biphenyl]-4ol, 2d (859.46 mg, $4.64 \mathrm{mmol}, 1$ eq.), $\mathrm{Et}_{3} \mathrm{~N}(0.712 \mathrm{~mL}, 5.11$ mmol, 1.1 eq.). Yield $1.59 \mathrm{~g}(100 \%) ; \mathbf{m p .} 103-104{ }^{\circ} \mathrm{C} ; \overline{\boldsymbol{v}}_{\max } / \mathbf{c m}^{-}$ ${ }^{1}$ (ATR) 3466, 3377, 3057, 3033, 3012, 1620, 1588, 1512, 1486, $1438,1408,1360,1085,1383,1324,1269,1234,1204,1165$, $1038,913,867,829,761,695 .{ }^{1} \mathbf{H}$ NMR $\left(400 \mathrm{MHz}, \mathrm{CDCl}_{3}\right) \delta$ $2.22(\mathrm{~s}, 3 \mathrm{H}), 2.31$ (s, $3 \mathrm{H}), 3.86(\mathrm{~s}, 2 \mathrm{H}), 6.71-6.76(\mathrm{~m}, 1 \mathrm{H})$, $6.81(\mathrm{~s}, 1 \mathrm{H}), 6.82(\mathrm{~d}, J=2.0 \mathrm{~Hz}, 1 \mathrm{H}), 7.18-7.23(\mathrm{~m}, 1 \mathrm{H}), 7.27$ $(\mathrm{t}, J=7.0 \mathrm{~Hz}, 2 \mathrm{H}), 7.34-7.38(\mathrm{~m}, 2 \mathrm{H}) .{ }^{13} \mathbf{C}$ NMR $(100 \mathrm{MHz}$, $\left.\mathrm{CDCl}_{3}\right) \delta 10.8,12.6,112.4,116.0,117.3,123.2,127.0,127.8$, $128.9,135.5,139.9,140.1,141.7,158.2,175.9$. LRMS (ES $\left.{ }^{+}\right)$ $\mathrm{C}_{17} \mathrm{H}_{16} \mathrm{~N}_{2} \mathrm{O}_{4} \mathrm{~S}$ requires 344; found $\left(\mathbf{E S}^{+}\right) 345[\mathrm{M}+\mathrm{H}]^{+}, 367$ $[\mathrm{M}+\mathrm{Na}]^{+} ; \quad$ HRMS $\quad\left(\mathbf{E S}^{+}\right) \quad \mathrm{C}_{17} \mathrm{H}_{17} \mathrm{~N}_{2} \mathrm{O}_{4} \mathrm{~S} \quad[\mathrm{M}+\mathrm{H}]^{+}$requires 345.0909; found $345.0921(\Delta=3.5 \mathrm{ppm})$. Microanalysis $\mathrm{C}_{17} \mathrm{H}_{16} \mathrm{~N}_{2} \mathrm{O}_{4} \mathrm{~S}$ requires: $\mathrm{C}, 59.29, \mathrm{H}, 4.68, \mathrm{~N}, 8.13, \mathrm{~S}, 9.31 \%$; found: C, 59.56, H, 4.67, N, 8.08, S, $9.17 \%$.

\subsubsection{4-Amino-3-methylphenyl 3',5'-dimethylisoxazole-4'- sulfonate, $3 \boldsymbol{e}$}

Using GP1: Starting with 3,5-dimethylisoxazole-4-sulfonyl chloride 1 ( $1 \mathrm{~g}, 5.11 \mathrm{mmol}, 1$ eq.), 4-amino-3-methylphenol $2 \mathrm{e}$ (692.54 mg , $5.62 \mathrm{mmol}, 1.1 \mathrm{eq}$.), $\mathrm{NaOH}(2 \mathrm{M}, 13 \mathrm{~mL}, 26 \mathrm{mmol})$. Recrystallization by $\mathrm{CHCl}_{3} /$ petroleum ether gave the title compound as light brown-coloured crystalline solid. Yield $1.26 \mathrm{~g}$ (88\%); mp. $96-97{ }^{\circ} \mathrm{C} ; \overline{\boldsymbol{v}}_{\text {max }} / \mathbf{c m}^{-1}$ (ATR) $3473,3374,3083,2986$, 1644 , 1586, 1528, 1498, 1438, 1356, 1198, 1306, 1272, 1150, $1117,1052,997,935,917,874 .{ }^{1} \mathbf{H}$ NMR $\left(400 \mathrm{MHz}_{2} \mathrm{CDCl}_{3}\right): \delta$ $2.09(\mathrm{~s}, 3 \mathrm{H}), 2.30(\mathrm{~s}, 3 \mathrm{H}), 2.36(\mathrm{~s}, 3 \mathrm{H}), 3.75$ (s, $2 \mathrm{H}), 6.52$ $6.56(\mathrm{~m}, 1 \mathrm{H}), 6.60-6.66(\mathrm{~m}, 1 \mathrm{H}), 6.74(\mathrm{~d}, J=2.0 \mathrm{~Hz}, 1 \mathrm{H}) .{ }^{13} \mathrm{C}$ NMR $\left(100 \mathrm{MHz}, \mathrm{CDCl}_{3}\right): \delta 10.7,12.4,17.4,112.1,114.9,120.4$, 123.4, 123.9, 140.4, 144.3, 158.2 , 175.4. LRMS (ES ${ }^{+}$ $\mathrm{C}_{12} \mathrm{H}_{14} \mathrm{~N}_{2} \mathrm{O}_{4} \mathrm{~S}$ requires 282; found $\left(\mathbf{E S}^{+}\right) 283[\mathrm{M}+\mathrm{H}]^{+}, 305$ $[\mathrm{M}+\mathrm{Na}]^{+} ;$HRMS $\left(\mathbf{E S}^{+}\right) \quad \mathrm{C}_{12} \mathrm{H}_{15} \mathrm{~N}_{2} \mathrm{O}_{4} \mathrm{~S} \quad[\mathrm{M}+\mathrm{H}]^{+}$requires 283.0753; found $283.0740(\Delta=-4.6 \mathrm{ppm})$. Microanalysis $\mathrm{C}_{12} \mathrm{H}_{14} \mathrm{~N}_{2} \mathrm{O}_{4} \mathrm{~S}$ requires: $\mathrm{C}, 51.05, \mathrm{H}, 5.00, \mathrm{~N}, 9.92, \mathrm{~S}, 11.36 \%$; found: C, 50.76, H, 5.19, N, 9.81, S, $11.04 \%$.

\subsubsection{2-(((3',5'-dimethylisoxazol-4'-yl)sulfonyl)oxy)benzene-} diazonium tetrafluoroborate, $\mathbf{4 a}$

Using GP3: Starting with amine 3a (1.30g, $4.85 \mathrm{mmol}, 1$ eq.), ethanol $(7 \mathrm{~mL})$, isoamyl nitrite $(0.782 \mathrm{~mL}, 5.82 \mathrm{mmol}, 1.2$ eq. $)$, $\mathrm{HBF}_{4} 48 \%$ (1.64 mL, $12.62 \mathrm{mmol}, 2.6$ eq.). The title compound was obtained as a colourless amorphous solid. Yield 1.691g (95 $\%) ; \overline{\boldsymbol{v}}_{\text {max }} / \mathbf{c m}^{-1}$ (ATR) 3104, 2998, 2290), 1573, 1478, 1442, 1408, $1365,1313,1275,1219,1204,1130,1050,1036,853,782,733$, 688, 651. ${ }^{1} \mathbf{H}$ NMR $\left(400 \mathrm{MHz}\right.$, acetone-d $\left.\mathrm{d}_{6}\right): \delta 2.46(\mathrm{~s}, 3 \mathrm{H}), 2.72$ $(\mathrm{s}, 3 \mathrm{H}), 8.01-8.12(\mathrm{~m}, 2 \mathrm{H}), 8.54(\mathrm{td}, J=8.0,1.0 \mathrm{~Hz}, 1 \mathrm{H}) 8.99$ $(\mathrm{dd}, J=8.0,1.0 \mathrm{~Hz}, 1 \mathrm{H}) .{ }^{13} \mathbf{C}$ NMR $\left(100 \mathrm{MHz}\right.$, acetone-d $\left.{ }_{6}\right): \delta$ 9.9, 12.4, 109.3, 110.6, 124.1, 129.9, 135.4, 144.6, 148.8, 157.8, 178.6. Microanalysis $\mathrm{C}_{11} \mathrm{H}_{10} \mathrm{BF}_{4} \mathrm{~N}_{3} \mathrm{O}_{4} \mathrm{~S}$, requires: $\mathrm{C}, 35.99, \mathrm{H}$, 2.75, N, 11.45, S, 8.73\%; found: C, 36.24, H, 2.95, N, 11.40, S, $8.96 \%$.

\subsection{7. $\quad\left(\left(\left(3^{\prime}, 5^{\prime}\right.\right.\right.$-dimethylisoxazol-4'-yl)sulfonyl $)$ oxy $)-6$ -} methylbenzenediazonium tetrafluoroborate, $\mathbf{4 b}$

Using GP3: Starting with amine 3b (800 mg, $2.83 \mathrm{mmol}, 1$ eq.), ethanol $(8 \mathrm{~mL})$, isoamyl nitrite $(0.46 \mathrm{~mL}, 3.39 \mathrm{mmol}, 1.2$ eq. $)$, $\mathrm{HBF}_{4} 48 \%$ (0.96 mL, $7.36 \mathrm{mmol}, 2.6$ eq.). The title compound was obtained as colourless amorphous solid. Yield 1.01 g (94 $\%$ ); $\overline{\boldsymbol{v}}_{\text {max }} / \mathbf{c m}^{-1}$ (ATR) 3140, 3108, 3082, 2996, 2947, 2266, 1596,
1566, 1479, 1413, 1263, 1212, 1025, 962, 817, 793, 722, 682, 632. ${ }^{1}$ H NMR (400 MHz, Acetone-d $\left.)_{6}\right): \delta 2.46(\mathrm{~s}, 3 \mathrm{H}), 2.73(\mathrm{~s}, 3$ H), 2.97 (s, $3 \mathrm{H}), 7.84(\mathrm{~d}, J=8.0 \mathrm{~Hz}, 1 \mathrm{H}), 7.93$ (dt, $J=8.0,1.0 \mathrm{~Hz}$, $1 \mathrm{H}), 8.37(\mathrm{t}, J=8.0 \mathrm{~Hz}, 1 \mathrm{H}) .{ }^{13} \mathbf{C}$ NMR $\left(100 \mathrm{MHz}\right.$, acetone-d $\left.\mathrm{d}_{6}\right)$ : $\delta$ 9.9, 12.4, 18.3, 109.4, 110.7, 121.2, 131.1, 143.5, 148.4, 148.9, 157.8, 178.5. Microanalysis $\mathrm{C}_{12} \mathrm{H}_{12} \mathrm{BF}_{4} \mathrm{~N}_{3} \mathrm{O}_{4} \mathrm{~S}$, requires: $\mathrm{C}$, 37.82, H, 3.17, N, 11.03, S, $8.41 \%$; found: C, 38.00, H, 2.92, N, $11.02, \mathrm{~S}, 8.21 \%$.

\subsubsection{1-(((3,5-dimethylisoxazol-4-yl)sulfonyl)oxy)naphthalene-2-} diazonium tetrafluoroborate, $4 c$

Using GP3: Starting with amine 3c (606 mg, $1.9 \mathrm{mmol}, 1$ eq.), ethanol $(5 \mathrm{~mL})$, isoamyl nitrite $(0.307 \mathrm{~mL}, 2.28 \mathrm{mmol}, 1.2$ eq. $)$, $\mathrm{HBF}_{4} 48 \%$ (0.64 mL, $4.95 \mathrm{mmol}, 2.6$ eq.). The title compound was obtained as yellowish-green coloured amorphous solid. Yield $668 \mathrm{mg}(84 \%) ; \overline{\boldsymbol{v}}_{\text {max }} / \mathbf{c m}^{-1}$ (ATR) 3120, 3081, 3069, 2984), 2242, 1625, 1578, 1563, 1510, 1405, 1368, 1273, 1245, 1227, 1207, 1174, 1126, 1060, 1043, 1019, 979, 873, 851, 833, 766. ${ }^{1} \mathbf{H}$ NMR (400 MHz, acetone-d $\left.\mathrm{d}_{6}\right): \delta 2.52(\mathrm{~s}, 3 \mathrm{H}), 2.79$ (s, $\left.3 \mathrm{H}\right), 8.06$ (ddd, $J=8.0,7.0,1.0 \mathrm{~Hz}, 1 \mathrm{H}), 8.20$ (d, $J=9.0 \mathrm{~Hz}, 1 \mathrm{H}), 8.25$ (ddd, $J=8.0,7.0,1.0 \mathrm{~Hz}, 1 \mathrm{H}), 8.54(\mathrm{~d}, J=8.0 \mathrm{~Hz}, 1 \mathrm{H}), 8.62(\mathrm{dd}, J=8.0$, $1.0 \mathrm{~Hz}, 1 \mathrm{H}), 9.20(\mathrm{~d}, J=9.0 \mathrm{~Hz}, 1 \mathrm{H}) .{ }^{13} \mathbf{C ~ N M R}(100 \mathrm{MHz}$, acetone- $\left.\mathrm{d}_{6}\right): \delta 10.0,12.5,111.0,119.7,122.3,126.9,130.3$, 131.3, 134.4, 147.2, 153.8, 157.8, 178.8. Microanalysis $\mathrm{C}_{15} \mathrm{H}_{12} \mathrm{BF}_{4} \mathrm{~N}_{3} \mathrm{O}_{4} \mathrm{~S}$, requires: C, 43.19, H, 2.90, N, 10.07, S, 7.69 $\%$; found: C, 43.30, H, 3.06, N, 9.98, S, $7.57 \%$.

4.3.9. Synthesis of 4-(((3,5-dimethylisoxazol-4-yl)sulfonyl)oxy)[1,1'-biphenyl]-3-diazonium tetrafluoroborate, $4 d$

Using GP3: Starting with amine 3d (1.15 g, 3.35 mmol, 1 eq.), ethanol $(4 \mathrm{~mL})$, isoamyl nitrite $(0.54 \mathrm{~mL}, 4.03 \mathrm{mmol}, 1.2$ eq.), $\mathrm{HBF}_{4} 48 \%$ (1.14 mL, $8.73 \mathrm{mmol}, 2.6$ eq.). The title compound was obtained as a yellow-coloured amorphous powder. Yield $1.24 \mathrm{~g}$ (97 \%); $\overline{\boldsymbol{v}}_{\max } / \mathbf{c m}^{-1}$ (ATR) 3107, 3070, 3056, 3035, 2275, $1586,1558,1515,1480,1439,1404,1367,1289,1271,1235$, 1202, 1153, 1129, 1061, 1030, 884, 852. ${ }^{\mathbf{1}} \mathbf{H}$ NMR (400 MHz, acetone- $\left.\mathrm{d}_{6}\right): \delta 2.49(\mathrm{~s}, 3 \mathrm{H}), 2.74(\mathrm{~s}, 3 \mathrm{H}), 7.53-7.63(\mathrm{~m}, 3 \mathrm{H})$, $7.82-7.88(\mathrm{~m}, 2 \mathrm{H}), 8.12(\mathrm{~d}, J=9.0 \mathrm{~Hz}, 1 \mathrm{H}), 8.77-8.81(\mathrm{~m}, 1$ H), $9.29(\mathrm{~d}, J=2.0 \mathrm{~Hz}, 1 \mathrm{H}) .{ }^{13} \mathbf{C}$ NMR $\left(100 \mathrm{MHz}\right.$, acetone-d $\left.\mathrm{d}_{6}\right): \delta$ $10.0,12.4,109.9,110.5,124.5,127.2,129.6,130.0,132.6,135.2$, 142.2, 142.3, 147.6, 157.8, 178.7. Microanalysis $\mathrm{C}_{17} \mathrm{H}_{14} \mathrm{BF}_{4} \mathrm{~N}_{3} \mathrm{O}_{4} \mathrm{~S}$, requires: $\mathrm{C}, 46.07, \mathrm{H}, 3.18, \mathrm{~N}, 9.48, \mathrm{~S}, 7.23 \%$; found: C, 46.28, H, 2.92, N, 9.43, S, $7.40 \%$.

4.3.10. Synthesis of 4-(((3,5-dimethylisoxazol-4-yl)sulfonyl)oxy)2-methylbenzenediazonium tetrafluoroborate, $\mathbf{4 e}$

Using GP10: Starting with amine 3e (500 mg, $1.77 \mathrm{mmol}, 1$ eq.), Ethanol $(6 \mathrm{~mL})$, isoamyl nitrite $(0.28 \mathrm{~mL}, 2.12 \mathrm{mmol}, 1.2$ eq.), $\mathrm{HBF}_{4} 48 \%$ (0.60 mL, $4.60 \mathrm{mmol}, 2.6$ eq.). The title compound was obtained as a colourless, crystalline, solid. Yield $574 \mathrm{mg} \mathrm{(85}$ $\%) ; \overline{\boldsymbol{v}}_{\max } / \mathbf{c m}^{-1}$ (ATR) 3110, 3048, 3029, 2271, 1603, 1587, 1563, 1499, 1471, 1436, 1404, 1379, 1362, 1313, 1274, 1204, 1124, 946, 889. ${ }^{1}$ H NMR (400 MHz, acetone-d $\left.{ }_{6}\right) \delta 2.38(\mathrm{~s}, 3 \mathrm{H}), 2.58$ $(\mathrm{s}, 3 \mathrm{H}), 2.98(\mathrm{~s}, 3 \mathrm{H}), 7.78(\mathrm{dd}, J=9.0,2.0 \mathrm{~Hz}, 1 \mathrm{H}), 7.88(\mathrm{~d}$, $J=2.0 \mathrm{~Hz}, 1 \mathrm{H}), 8.91(\mathrm{~d}, J=9.0 \mathrm{~Hz}, 1 \mathrm{H}) .{ }^{13} \mathrm{C}$ NMR $(100 \mathrm{MHz}$, acetone- $\left.\mathrm{d}_{6}\right) \delta 9.9,12.0,18.1,111.3,114.8,123.1,126.5,135.8$, 148.5, 157.0, 157.6, 177.2. Microanalysis $\mathrm{C}_{12} \mathrm{H}_{12} \mathrm{BF}_{4} \mathrm{~N}_{3} \mathrm{O}_{4} \mathrm{~S}$, requires: $\mathrm{C}, 37.82, \mathrm{H}, 3.17, \mathrm{~N}, 11.03, \mathrm{~S}, 8.41 \%$; found: $\mathrm{C}, 37.67$, $\mathrm{H}, 3.24, \mathrm{~N}, 10.98, \mathrm{~S}, 8.59 \%$.

\section{4. $\mathrm{TiCl}_{3}$ Reactions}

\subsubsection{Reaction of 4 a using $\mathrm{TiCl}_{3}$}

Using GP4: Starting with 4a (1.32 g, 3.60 mmol, 1 eq.), acetone (6 $\mathrm{mL}), \mathrm{TiCl}_{3}(1.29 \mathrm{M}$ in $\mathrm{HCl}, 2$ eq., $5.59 \mathrm{~mL}, 7.21 \mathrm{mmol})$. The 
crude was purified by column chromatography (ethyl acetate: petroleum ether; 2:8 v:v) to afford 3a, 8a, 10a, 12a and 13a.

\section{2-Aminophenyl 3,5-dimethylisoxazole-4-sulfonate, 3a}

Brown-coloured crystalline solid. Yield $35.4 \mathrm{mg}(10 \%)$. $\mathbf{R}_{f} 0.21$ $\left(100 \% \mathrm{CH}_{2} \mathrm{Cl}_{2}\right) ; \overline{\boldsymbol{v}}_{\text {max }} / \mathbf{c m}^{-1}$ (ATR) 3386, 3075, 3043, 1623, 1587, 1502, 1436, 1377, 1161, 1362, 1314, 1269, 1205, 1115, 1030, 878, 804, 758, 710. ${ }^{1} \mathbf{H}$ NMR $\left(400 \mathrm{MHz}, \mathrm{CDCl}_{3}\right): \delta 2.26(\mathrm{~s}, 3$ H), 2.35 (s, 3 H), 3.79 (br. s., 2 H), 6.56 - 6.63 (m, 1 H), 6.69 (dd, $J=8.0,1.0 \mathrm{~Hz}, 1 \mathrm{H}), 6.80$ (dd, $J=8.0,1.0 \mathrm{~Hz}, 1 \mathrm{H}), 6.98-7.04$ (m, $1 \mathrm{H}) .{ }^{13} \mathrm{C}$ NMR $\left(100 \mathrm{MHz}, \mathrm{CDCl}_{3}\right) \delta 10.7,12.5,112.3,117.5$, 118.6, 122.9, 128.5, 136.1, 139.8, 158.2, 175.7. LRMS (ES $\left.{ }^{+}\right)$ $\mathrm{C}_{11} \mathrm{H}_{12} \mathrm{~N}_{2} \mathrm{O}_{4} \mathrm{~S}$ requires 268; found $\left(\mathbf{E S}^{+}\right) 269[\mathrm{M}+\mathrm{H}]^{+},\left(\mathbf{E S}^{-}\right) 267$ $[\mathrm{M}-\mathrm{H}] \quad ;$ HRMS (ES $\left.{ }^{+}\right) \mathrm{C}_{11} \mathrm{H}_{12} \mathrm{~N}_{2} \mathrm{O}_{4} \mathrm{SNa}[\mathrm{M}+\mathrm{Na}]^{+}$requires 291.0415; found $291.0423(\Delta=2.74 \mathrm{ppm})$.

\section{Phenyl 3,5-dimethylisoxazole-4-sulfonate, 10a}

Colourless crystalline solid. Yield $146.94 \mathrm{mg}$ (44\%). $\mathbf{R}_{f} 0.60$ (2:8 ethyl acetate: petroleum ether; v:v); m.p. $65.5-66.5{ }^{\circ} \mathrm{C}$; $\overline{\boldsymbol{v}}_{\text {max }} / \mathbf{c m}^{-1}$ (ATR): 3066, 2970 1584, 1486, 1436, 1406, 1363, $1268,1204,1178,1152,1121 ;{ }^{1} \mathbf{H}$ NMR $\left(400 \mathrm{MHz}, \mathrm{CDCl}_{3}\right) \delta$ 2.29 (s, $3 \mathrm{H}), 2.34$ (s, $3 \mathrm{H}), 7.02$ - 7.07 (m, $2 \mathrm{H}), 7.27$ - 7.38 (m, 3 H). ${ }^{13} \mathbf{C}$ NMR $\left(100 \mathrm{MHz}, \mathrm{CDCl}_{3}\right) \delta 10.6,12.3,112.1,122.4$, $127.8,130.0,148.9,158.0,175.5$. LRMS (EI) $\mathrm{C}_{11} \mathrm{H}_{11} \mathrm{NO}_{4} \mathrm{~S}$ requires 253; found (EI) $253\left[\mathrm{M}^{+}\right]$; HRMS (EI) $\mathrm{C}_{11} \mathrm{H}_{11} \mathrm{NO}_{4} \mathrm{~S}$ $\left[\mathrm{M}^{+}\right]$requires 253.0723; found 253.0723, ( $\left.\Delta=0 \mathrm{ppm}\right)$.

\section{2-(3,5-Dimethylisoxazol-4-yl)phenol, 8a}

Colourless, crystalline, solid. Yield $95.25 \mathrm{mg}$ (14\%). $\mathbf{R}_{f} 0.67$ (100\% $\left.\mathrm{CH}_{2} \mathrm{Cl}_{2}\right)$; m.p. $61-62{ }^{\circ} \mathrm{C} ; \overline{\boldsymbol{v}}_{\max } / \mathbf{c m}^{-1}$ (ATR) 3515-3328, 3128, 3072, 3039, 2992, 2971, 2931, 1642, 1607, 1576, 1504, $1479,1456,1436,1419,1331,1238,1169,1147,1096,1037$, 1014, 994, 951, 828. ${ }^{\mathbf{1}} \mathbf{H}$ NMR $\left(400 \mathrm{MHz}, \mathrm{CDCl}_{3}\right) \delta 2.10(\mathrm{~s}, 3$ H), 2.26 (s, $3 \mathrm{H}), 3.90$ - 6.55 (br.s., $1 \mathrm{H}), 6.88$ - 6.96 (m, $2 \mathrm{H})$, $7.00(\mathrm{dd}, J=7.0,2.0 \mathrm{~Hz}, 1 \mathrm{H}), 7.20-7.25(\mathrm{~m}, 1 \mathrm{H}) .{ }^{13} \mathbf{C} \mathbf{~ N M R}$ $\left(100 \mathrm{MHz}, \mathrm{CDCl}_{3}\right): \delta 10.5,11.6,112.1,116.1,116.2,120.7$, 130.0, 131.3, 154.1, 160.0, 167.0. LRMS (ES) $\mathrm{C}_{11} \mathrm{H}_{11} \mathrm{NO}_{2}$ requires 189; found (ES) $188[\mathrm{M}-\mathrm{H}]$; HRMS (ES ${ }^{+}$) $\mathrm{C}_{11} \mathrm{H}_{12} \mathrm{NO}_{2}$ $[\mathrm{M}+\mathrm{H}]^{+}$requires 190.0868; found $190.0873(\Delta=2.6 \mathrm{ppm})$.

$\left(3 a R^{*}, 9 b R^{*}\right)-3,9 b$-Dimethyl-3a,9b

dihydrobenzo[5,6][1,2]oxathiino[3,4-d]isoxazole-4,4-dioxide, 12a

Colourless, crystalline solid. Yield $50.1 \mathrm{mg}(15 \%) . \mathbf{R}_{f} 0.63$ $\left(100 \% \mathrm{CH}_{2} \mathrm{Cl}_{2}\right) ;{ }^{1} \mathbf{H}$ NMR $\left(500 \mathrm{MHz}, \mathrm{CDCl}_{3}\right) \delta 1.87(\mathrm{~s}, 3 \mathrm{H})$, 2.31 (d, $J=1.0 \mathrm{~Hz}, 3 \mathrm{H}), 4.65$ (br.m, $1 \mathrm{H}), 7.16$ (dd, $J=8.0,1.4 \mathrm{~Hz}$, $1 \mathrm{H}), 7.37$ - $7.41(\mathrm{~m}, 1 \mathrm{H}), 7.43-7.47(\mathrm{~m}, 1 \mathrm{H}), 7.64$ (dd, $J=8.0$, $2.0 \mathrm{~Hz}, 1 \mathrm{H}) .{ }^{13} \mathrm{CNMR}\left(125 \mathrm{MHz}, \mathrm{CDCl}_{3}\right) \delta 13.2,27.8,74.0$, 87.0, 119.5, 125.4, 127.4, 128.3, 131.1, 148.5, 148.8. LRMS $\left(\mathbf{E S}^{+}\right) \mathrm{C}_{11} \mathrm{H}_{11} \mathrm{NO}_{4} \mathrm{~S}$ requires 253; found $\left(\mathbf{E S}^{+}\right) 254[\mathrm{M}+\mathrm{H}]^{+}, 276$ $[\mathrm{M}+\mathrm{Na}]^{+},\left(\mathbf{E S}^{-}\right) 252[\mathrm{M}-\mathrm{H}]^{-} ;$HRMS $\left(\mathbf{E S}^{+}\right) \mathrm{C}_{11} \mathrm{H}_{11} \mathrm{NO}_{4} \mathrm{SNa}$ $[\mathrm{M}+\mathrm{Na}]^{+}$requires 276.0301; found $276.0295(\Delta=-2.17 \mathrm{ppm})$.

1-(4-Methyl-2,2-dioxidobenzo[e][1,2]oxathiin-3-yl)ethan-1-one, 13a

Colourless, crystalline solid. Yield $43.98 \mathrm{mg}(14 \%) . \mathbf{R}_{f} 0.38$ $\left(100 \% \mathrm{CH}_{2} \mathrm{Cl}_{2}\right) ; \overline{\boldsymbol{v}}_{\text {max }} / \mathbf{c m}^{-1}$ (ATR) 2926, 2851), 1691, 15841553 , $1485,1447,1426,1365,1354,1313,1279,1203,1170,1118$, 1089, 1034, 1018, 958, 870, 794, 764. ${ }^{1}$ HNMR (400 MHz, $\left.\mathrm{CDCl}_{3}\right) \delta 2.54(\mathrm{~s}, 3 \mathrm{H}), 2.68(\mathrm{~s}, 3 \mathrm{H}), 7.34(\mathrm{dd}, J=8.0,1.0 \mathrm{~Hz}, 1$ H), $7.40-7.45(\mathrm{~m}, 1 \mathrm{H}), 7.56-7.61(\mathrm{~m}, 1 \mathrm{H}), 7.74$ (dd, $J=8.0$, $1.0 \mathrm{~Hz}, 1 \mathrm{H}) .{ }^{13} \mathrm{CNMR}\left(100 \mathrm{MHz}, \mathrm{CDCl}_{3}\right) \delta 16.7,31.7,119.4$, 122.0, 126.5, 127.8, 133.4, 134.1, 146.9, 150.1, 192.6. LRMS $\left(\mathbf{E S}^{+}\right) \mathrm{C}_{11} \mathrm{H}_{10} \mathrm{O}_{4} \mathrm{~S}$ requires 238; found $\left(\mathbf{E S}^{+}\right) 239[\mathrm{M}+\mathrm{H}]^{+}, 261$
$[\mathrm{M}+\mathrm{Na}]^{+},\left(\mathbf{E S}^{-}\right) 237[\mathrm{M}-\mathrm{H}]^{-} ;$HRMS $\left(\mathbf{E S}^{+}\right) \mathrm{C}_{11} \mathrm{H}_{11} \mathrm{O}_{4} \mathrm{SNa}$ $[\mathrm{M}+\mathrm{Na}]^{+}$requires 261.0192; found $261.0184(\Delta=-3.07 \mathrm{ppm})$.

\subsubsection{Reaction of $4 \mathrm{~b}$ with $\mathrm{TiCl}_{3}$}

According to (GP4) the starting materials were mixed: $\mathbf{4 b}(1.2 \mathrm{~g}$, $3.14 \mathrm{mmol}, 1$ eq.), acetone ( $5 \mathrm{~mL}), \mathrm{TiCl}_{3}(1.29 \mathrm{M}$ in $\mathrm{HCl}, 2$ eq., $4.9 \mathrm{~mL}, 6.29 \mathrm{mmol})$. The crude material was purified by column chromatography (2:8 ethyl acetate: petroleum ether; v/v) and then preparative HPLC resulting in the isolation of the following products:

\section{3,5-Dimethylisoxazole-4-sulfonate, $9 \boldsymbol{b}$}

The title compound was isolated by preparative HPLC (ACE$127-2546,254 \mathrm{~nm}, \mathrm{n}$-hexane/ethyl acetate $=90 / 10$, flow rate $=$ $1.0 \mathrm{ml} / \mathrm{min}$, retention time $(\mathrm{t})=6.217 \mathrm{~min}$.) as a colourless, crystalline solid. Yield $85.06 \mathrm{mg}(9 \%)$. $\mathbf{R}_{f} 0.72$ (2:8 ethyl acetate: petroleum ether; v/v); ${ }^{1} \mathbf{H}$ NMR $\left(400 \mathrm{MHz}, \mathrm{CD}_{2} \mathrm{Cl}_{2}\right) \delta$ 2.22 (s, $3 \mathrm{H}), 2.28(\mathrm{~s}, 3 \mathrm{H}), 2.34$ (s, $3 \mathrm{H}), 7.11-7.19$ (m, $3 \mathrm{H})$. ${ }^{13}$ C NMR (100 MHz, $\left.\mathrm{CDCl}_{3}\right) \delta 10.8,12.7,20.3,112.9,121.8$, 127.0, 129.7, 139.0, 145.0, 158.3, 175.6. LRMS $\left(\mathbf{E S}^{+}\right)$ $\mathrm{C}_{12} \mathrm{H}_{12} \mathrm{ClNO}_{4} \mathrm{~S}$ requires 301; found $\left(\mathbf{E S}^{+}\right) 302[\mathrm{M}+\mathrm{H}]^{+}$for ${ }^{35} \mathrm{Cl}$, $304[\mathrm{M}+\mathrm{H}]^{+}$for ${ }^{37} \mathrm{Cl}, 324[\mathrm{M}+\mathrm{Na}]^{+}$for ${ }^{35} \mathrm{Cl}$; HRMS $\left(\mathbf{E S}^{+}\right.$) $\mathrm{C}_{12} \mathrm{H}_{13} \mathrm{ClNO}_{4} \mathrm{~S}[\mathrm{M}+\mathrm{H}]^{+}$requires 302.0244; found 302.0246 for ${ }^{35} \mathrm{Cl}(\Delta=-0.662 \mathrm{ppm})$.

\section{m-Tolyl 3,5-dimethylisoxazole-4-sulfonate, $\mathbf{1 0 b}$}

The title compound was isolated by preparative HPLC (ACE$127-2546,254 \mathrm{~nm}, \mathrm{n}$-hexane $/$ ethyl acetate $=90 / 10$, flow rate $=$ $1.0 \mathrm{ml} / \mathrm{min}$, retention time $(\mathrm{t})=5.808 \mathrm{~min}$.) as a colourless, crystalline solid. Yield $150.9 \mathrm{mg}(18 \%)$. $\mathbf{R}_{f} 0.82$ (2:8 ethyl acetate: petroleum ether; v/v); ${ }^{1} \mathbf{H}$ NMR $\left(400 \mathrm{MHz}, \mathrm{CDCl}_{3}\right) \delta$ 2.26 (s, $3 \mathrm{H}), 2.27$ (s, $3 \mathrm{H}), 2.32(\mathrm{~s}, 3 \mathrm{H}), 6.75$ (dd, J=8.0, $2.0 \mathrm{~Hz}$, $1 \mathrm{H}), 6.83(\mathrm{~s}, 1 \mathrm{H}), 7.05(\mathrm{~d}, J=7.0 \mathrm{~Hz}, 1 \mathrm{H}), 7.13-7.18(\mathrm{~m}, 1 \mathrm{H})$. ${ }^{13}$ C NMR $\left(100 \mathrm{MHz}, \mathrm{CDCl}_{3}\right): \delta=10.7,12.5,21.3,112.3,119.1$, 122.9, 128.5, 129.6, 140.5, 148.9, 158.1, 175.4. LRMS (ES $\left.{ }^{+}\right)$ $\mathrm{C}_{12} \mathrm{H}_{13} \mathrm{NO}_{4} \mathrm{~S}$ requires 267; found $\left(\mathbf{E S}^{+}\right) 268[\mathrm{M}+\mathrm{H}]^{+}$; HRMS $\left(\right.$ ES $\left.^{+}\right) \quad \mathrm{C}_{12} \mathrm{H}_{13} \mathrm{NO}_{4} \mathrm{SNa} \quad[\mathrm{M}+\mathrm{Na}]^{+}$requires 290.0463 ; found 290.0477 ( $\Delta=4.8 \mathrm{ppm})$.

\section{2-(3,5-dimethylisoxazol-4-yl)-6-methylphenol, $\mathbf{8 b}$}

Colourless crystalline dolid. Yield $433 \mathrm{mg}$ (68 \%). m.p. 51-52 ${ }^{\circ} \mathrm{C} ; \mathbf{R}_{f} 0.25$ (3:7 ethyl acetate: petroleum ether; v/v); $\overline{\boldsymbol{v}}_{\text {max }} / \mathbf{c m}^{-1}$ (ATR) 3521-3269, 3034, 2976, 2924, 1633, 1603, 1574, 1464, 1437, 1411, 1378, 1318, 1288, 1253, 1235, 1155, 1086, 1014, 994, 945, 893, 869, 787, 769. ${ }^{1} \mathbf{H}$ NMR $\left(400 \mathrm{MHz}, \mathrm{CDCl}_{3}\right) \delta 1.97$ $(\mathrm{s}, 3 \mathrm{H}), 1.99(\mathrm{~s}, 3 \mathrm{H}), 2.18(\mathrm{~s}, 3 \mathrm{H}), 5.81(\mathrm{~s}, 1 \mathrm{H}), 6.76-6.80(\mathrm{~m}$, $2 \mathrm{H}), 7.13(\mathrm{t}, J=8.0 \mathrm{~Hz}, 1 \mathrm{H}),{ }^{13} \mathbf{C}$ NMR $\left(100 \mathrm{MHz}, \mathrm{CDCl}_{3}\right) \delta$ $10.5,11.5,20.0,110.3,113.2,115.1,121.9,129.7,139.2,154.8$, 160.4, 167.41. LRMS (ES $\left.{ }^{+}\right) \mathrm{C}_{12} \mathrm{H}_{13} \mathrm{NO}_{2}$ requires 203; found $\left(\mathbf{E S}^{+}\right) 204[\mathrm{M}+\mathrm{H}]^{+}$, (ES) $202[\mathrm{M}-\mathrm{H}] ;$ HRMS $\left(\mathbf{E S}^{+}\right) \mathrm{C}_{12} \mathrm{H}_{14} \mathrm{NO}_{2}$ $[\mathrm{M}+\mathrm{H}]^{+}$requires 204.1025; found $204.1028(\Delta=1.7 \mathrm{ppm})$.

(3aR*,9bR*)-3,9,9b-Trimethyl-3a,9b-

dihydrobenzo[5,6][1,2]oxathiino[3,4-d]isoxazole-4,4-dioxide, 12b

Colourless foam. Yield $24 \mathrm{mg}(2 \%)$. $\mathbf{R}_{f} 0.45$ (3:7 ethyl acetate: petroleum ether; v/v). ${ }^{1} \mathbf{H}$ NMR $\left(500 \mathrm{MHz}, \mathrm{CDCl}_{3}\right) \delta 1.74(\mathrm{~s}, 3$ H), 2.23 (d, J=1.0 Hz, $3 \mathrm{H}), 2.58$ (s, $3 \mathrm{H}), 4.56$ (br.m, $1 \mathrm{H}), 6.92$ $(\mathrm{dd}, J=8.0,1.0 \mathrm{~Hz}, 1 \mathrm{H}), 7.10(\mathrm{dd}, J=7.0,1.0 \mathrm{~Hz}, 1 \mathrm{H}), 7.18$ $7.23(\mathrm{~m}, 1 \mathrm{H}) .{ }^{13} \mathrm{C} \mathbf{N M R}\left(125 \mathrm{MHz}, \mathrm{CDCl}_{3}\right): \delta=12.9,21.3,27.9$, 76.1, 88.5, 117.4, 124.0, 129.9, 131.1, 139.5, 147.5, 148.7. LRMS (ES $\left.{ }^{+}\right) \quad \mathrm{C}_{12} \mathrm{H}_{13} \mathrm{NO}_{4} \mathrm{~S}$ requires 267; found $\left(\mathbf{E S}^{+}\right) 268$ $[\mathrm{M}+\mathrm{H}]^{+}$; HRMS (EI) $\mathrm{C}_{12} \mathrm{H}_{14} \mathrm{NO}_{4} \mathrm{~S}\left[\mathrm{M}^{+}\right]$requires 267.0463; found 267.0473, $(\Delta=3.74 \mathrm{ppm})$.

4.4.3. Reaction of $4 \mathrm{c}$ with $\mathrm{TiCl}_{3}$ 
According to (GP4) the starting materials were mixed: 4c $\left(180 \mathrm{mg}, 0.43 \mathrm{mmol}, 1\right.$ eq.), acetone $(3 \mathrm{~mL}), \mathrm{TiCl}_{3}(1.29 \mathrm{M}$ in $\mathrm{HCl}, 2$ eq., $0.66 \mathrm{~mL}, 0.86 \mathrm{mmol})$. The crude product was purified by column chromatography (2:8 ethyl acetate: petroleum ether; $\mathrm{v} / \mathrm{v}$ ) which afforded $\mathbf{1 5}, \mathbf{1 0 c}, \mathbf{8 c}$ and $\mathbf{1 2 c}$ as shown below.

\section{2-Chloronaphthalene, 15}

Colourless, crystalline solid. Yield $44 \mathrm{mg}(63 \%) . \mathbf{R}_{f} 0.92(2: 8$ ethyl acetate: petroleum ether; v/v); ${ }^{\mathbf{1}} \mathbf{H N M R}\left(400 \mathrm{MHz}, \mathrm{CDCl}_{3}\right)$ $\delta 27.42$ - 7.57 (m, $3 \mathrm{H}), 7.76-7.88(\mathrm{~m}, 4 \mathrm{H}) .{ }^{13}$ CNMR $(100$ $\left.\mathrm{MHz}, \mathrm{CDCl}_{3}\right): \delta=126.1,126.6,126.8,126.9,127.1,127.8,129.5$, $131.6,131.6,134.0$. This data is essentially identical to that reported in the literature. ${ }^{43}$

\section{Naphthalen-2-yl 3,5-dimethylisoxazole-4-sulfonate, 10c}

Off-white coloured crystalline solid. Yield $23 \mathrm{mg}$ (18\%). $\mathbf{R}_{f}$ 0.66 (2:8 ethyl acetate: petroleum ether; v/v); ${ }^{1}$ HNMR (400 $\left.\mathrm{MHz}, \mathrm{CDCl}_{3}\right) \delta 2.39(\mathrm{~d}, J=3.0 \mathrm{~Hz}, 6 \mathrm{H}), 7.20(\mathrm{dd}, J=9.0,2.4 \mathrm{~Hz}$, $1 \mathrm{H}), 7.53$ - 7.60 (m, $3 \mathrm{H}), 7.80-7.91$ (m, $3 \mathrm{H}) .{ }^{13}$ CNMR (100 $\left.\mathrm{MHz}, \mathrm{CDCl}_{3}\right) \delta 10.8,12.5,120.0,120.7,126.9,127.3,127.9$, 127.9, 130.2, 132.1, 133.4, 146.4, 158.1, 175.5. LRMS (ES $\left.{ }^{+}\right)$ $\mathrm{C}_{15} \mathrm{H}_{13} \mathrm{NO}_{4} \mathrm{~S}$ requires 303; found $\left(\mathbf{E S}^{+}\right) 326[\mathrm{M}+\mathrm{Na}]^{+}$, (ES $\left.^{-}\right) 302$ [M-H] ; HRMS (EI) $\mathrm{C}_{15} \mathrm{H}_{13} \mathrm{NO}_{4} \mathrm{~S}\left[\mathrm{M}^{+}\right.$] requires 303.0557; found $303.0558(\Delta=-0.594 \mathrm{ppm})$.

\section{1-(3,5-Dimethylisoxazol-4-yl)naphthalen-2-ol, 8c}

Off-white crystalline solid. Yield $21 \mathrm{mg}(20 \%)$. m.p. 86-87 ${ }^{\circ} \mathrm{C}$; $\mathbf{R}_{f} 0.12\left(100 \% \mathrm{CH}_{2} \mathrm{Cl}_{2}\right) ; \overline{\boldsymbol{v}}_{\text {max }} / \mathbf{c m}^{-1}$ (ATR) 3384, 3210, 3146, 3060, 2926, 2799, 1616, 1592, 1502, 1469, 1439, 1404, 1374, $1358,1333,1302,1267,1220,1184,1122,1083,1039,1027$, 965, 919, 828, 754. ${ }^{\mathbf{1}} \mathbf{H}$ NMR $\left(400 \mathrm{MHz}, \mathrm{CDCl}_{3}\right) \delta 2.10(\mathrm{~s}, 3 \mathrm{H})$, 2.29 (s, $3 \mathrm{H}), 5.32$ - 5.54 (br.s, $1 \mathrm{H}), 7.33$ (dt, $J=8.0,1.0 \mathrm{~Hz}, 1 \mathrm{H})$, 7.37 - 7.49 (m, $2 \mathrm{H}), 7.84$ - 7.91, (m, $2 \mathrm{H}) .{ }^{13} \mathbf{C}$ NMR $(100 \mathrm{MHz}$, $\left.\mathrm{CDCl}_{3}\right) \delta 10.5,11.6,107.8,117.5,123.6,123.7,127.2,128.5$, 129.0, 130.8, 132.9, 133.4, 152.3, 161.1, 168.6. LRMS (ES ${ }^{+}$ $\mathrm{C}_{15} \mathrm{H}_{13} \mathrm{NO}_{2}$ requires 239; found $\left(\mathbf{E S}^{+}\right) 240[\mathrm{M}+\mathrm{H}]^{+}, 262[\mathrm{M}+\mathrm{Na}]^{+}$, (ES) $238[\mathrm{M}-\mathrm{H}]^{-}$; HRMS $\left(\mathbf{E S}^{+}\right) \mathrm{C}_{15} \mathrm{H}_{14} \mathrm{NO}_{2}[\mathrm{M}+\mathrm{H}]^{+}$requires 240.1019; found $240.1013(\Delta=-2.52)$.

$\left(3 a R^{*}, 11 c R^{*}\right)-3,11 c-$ Dimethyl-3a,11c-

dihydronaphtho $\left[1^{\prime}, 2^{\prime}: 5,6\right][1,2]$ oxathiino $[3,4-d]$ isoxazole-4,4dioxide, $12 c$

The title compound was isolated by column chromatography as a colourless, crystalline, solid. Yield $10 \mathrm{mg}(8 \%)$. $\mathbf{R}_{f} 0.24(100 \%$ $\left.\mathrm{CH}_{2} \mathrm{Cl}_{2}\right) .{ }^{1} \mathbf{H}$ NMR $\left(400 \mathrm{MHz}, \mathrm{CDCl}_{3}\right) \delta 1.93(\mathrm{~s}, 3 \mathrm{H}), 2.30(\mathrm{~d}$, $J=1.0 \mathrm{~Hz}, 3 \mathrm{H}), 4.65$ (br.m, $1 \mathrm{H}), 7.17$ (d, $J=9 \mathrm{~Hz}, 1 \mathrm{H}), 7.45$ $7.51(\mathrm{~m}, 1 \mathrm{H}), 7.58(\mathrm{~s}, 1 \mathrm{H}), 7.79-7.85(\mathrm{~m}, 2 \mathrm{H}), 8.49(\mathrm{~d}, J=1.0$ $\mathrm{Hz}, 1 \mathrm{H}) .{ }^{13} \mathbf{C}$ NMR $\left(100 \mathrm{MHz}, \mathrm{CDCl}_{3}\right): \delta=13.1,28.7,75.9$, $89.1,118.2,126.3,126.9,127.8,129.1,132.4,132.9,146.2$, 147.6. LRMS (ES $\left.{ }^{+}\right) \mathrm{C}_{15} \mathrm{H}_{13} \mathrm{NO}_{4} \mathrm{~S}$ requires 303; found $\left(\mathbf{E S}^{+}\right) 304$ $[\mathrm{M}+\mathrm{H}]^{+},(\mathbf{E S}) 302[\mathrm{M}-\mathrm{H}]$; HRMS $\left(\mathbf{E S}^{+}\right) \mathrm{C}_{15} \mathrm{H}_{14} \mathrm{NO}_{4} \mathrm{~S}[\mathrm{M}+\mathrm{H}]^{+}$ requires 304.0638; found $304.0636(\Delta=-0.67 \mathrm{ppm})$.

\subsubsection{Reaction of $4 \mathrm{~d}$ with $\mathrm{TiCl}_{3}$}

According to (GP4) the starting materials were mixed: $4 \mathrm{~d}(1.03 \mathrm{~g}$, $2.32 \mathrm{mmol}, 1$ eq.), acetone ( $9 \mathrm{~mL}), \mathrm{TiCl}_{3}(1.29 \mathrm{M}$ in $\mathrm{HCl}, 2$ eq., $3.6 \mathrm{~mL}, 4.65 \mathrm{mmol})$. The crude product was purified by column chromatography (2:8 ethyl acetate: petroleum ether; v/v) to afford 8d, 10d, 12d and 13d.

\section{[1,1'-Biphenyl]-4-yl 3,5-dimethylisoxazole-4-sulfonate, 10d}

Colourless crysyalline solid. Yield $305 \mathrm{mg}$ (40\%). m.p. 97-98 ${ }^{\circ} \mathrm{C} ; \quad \mathbf{R}_{f} 0.69$ (2:8 ethyl acetate: petroleum ether; v/v); $\overline{\boldsymbol{v}}_{\text {max }} / \mathbf{c m}^{-1}$ (ATR) 3078, 3059, 3039, 2987, 1584, 1517, 1484, 1439, 1405, $1392,1361,1272,1215,1201,1185,1162,1122,1045,1016$,
982, 945, 864, 847, 758. ${ }^{\mathbf{1}} \mathbf{H}$ NMR $\left(400 \mathrm{MHz}, \mathrm{CDCl}_{3}\right) \delta 2.40(\mathrm{~s}$, $3 \mathrm{H}), 2.45(\mathrm{~s}, 3 \mathrm{H}), 7.38-7.44(\mathrm{~m}, 1 \mathrm{H}), 7.45-7.51(\mathrm{~m}, 2 \mathrm{H})$, 7.54 - $7.63(\mathrm{~m}, 4 \mathrm{H}) .{ }^{13} \mathrm{C}$ NMR $\left(100 \mathrm{MHz}, \mathrm{CDCl}_{3}\right) \delta 10.8,12.5$, $112.2,122.7,127.1,128.5,129.0,139.4,140.9,148.2,158.1$, 175.5. LRMS (ES $\left.{ }^{+}\right) \mathrm{C}_{17} \mathrm{H}_{15} \mathrm{NO}_{4} \mathrm{~S}$ requires 329; found $\left(\mathbf{E S}^{+}\right) 330$ $[\mathrm{M}+\mathrm{H}]^{+}, 352[\mathrm{M}+\mathrm{Na}]^{+}$; HRMS (ES $\left.{ }^{+}\right) \mathrm{C}_{17} \mathrm{H}_{16} \mathrm{NO}_{4} \mathrm{~S}[\mathrm{M}+\mathrm{H}]^{+}$ requires 330.0795; found $330.0791(\Delta=-1.08 \mathrm{ppm})$.

\section{2-(3,5-Dimethylisoxazol-4-yl)-[1,1'-biphenyl]-3-ol, 8d}

Colourless crystalline solid. Yield $160 \mathrm{mg}$ (26\%). m.p. 87-88 ${ }^{\circ} \mathrm{C} ; \mathbf{R}_{f} 0.35$ (2:8 ethyl acetate: petroleum ether; v/v); $\overline{\boldsymbol{v}}_{\text {max }} / \mathbf{c m}^{-1}$ (ATR) 3406 br., 3068, 3031, 2925, 2856, 1642, 1589, 1479, 1439, 1378, 1361, 1269, 1206, 1169, 1125, 1075, 1044, 864, 832, 762, 694. ${ }^{1}$ H NMR (400 MHz, $\left.\mathrm{CDCl}_{3}\right) \delta 2.14(\mathrm{~s}, 3 \mathrm{H}), 2.30$ (s, 3 H), $5.34-6.53(\mathrm{~m}, 1 \mathrm{H}), 7.02(\mathrm{~d}, J=8.0 \mathrm{~Hz}, 1 \mathrm{H}), 7.23(\mathrm{~d}, J=2.0$ $\mathrm{Hz}, 1 \mathrm{H}), 7.25$ (dt, J=7.0, $2.0 \mathrm{~Hz}, 1 \mathrm{H}), 7.32-7.37$ (m, $2 \mathrm{H}), 7.44$ - $7.49(\mathrm{~m}, 3 \mathrm{H}) .{ }^{13} \mathbf{C}$ NMR $\left(100 \mathrm{MHz}, \mathrm{CDCl}_{3}\right): \delta=10.7,11.7$, $112.2,116.6,116.7,126.7,127.0,128.7,128.9,129.8,133.9$, 140.3, 153.8, 160.1, 167. LRMS (ES $\left.{ }^{+}\right) \mathrm{C}_{17} \mathrm{H}_{15} \mathrm{NO}_{2}$ requires 265; found $\left(\mathbf{E S}^{+}\right) 266[\mathrm{M}+\mathrm{H}]^{+}$, (ES) $264[\mathrm{M}-\mathrm{H}]^{-}$; HRMS (EI) $\mathrm{C}_{17} \mathrm{H}_{15} \mathrm{NO}_{2}[\mathrm{M}]^{+.}$requires 265.1097; found $265.1087(\Delta=-3.999$ $\mathrm{ppm})$.

(3aR*,9bR*)-3,9b-dimethyl-8-phenyl-3a,9bdihydrobenzo[5,6][1,2]oxathiino[3,4-d]isoxazole-4,4-dioxide, 12d

Colourless crystalline solid Yield $153 \mathrm{mg}$ (20\%). $\mathbf{R}_{f} 0.29$ (2:8 ethyl acetate: petroleum ether; v/v); ${ }^{1} \mathbf{H}$ NMR (500 $\mathbf{M H z}, \mathrm{CDCl}_{3}$ ) $\delta 1.92(\mathrm{~s}, 3 \mathrm{H}), 2.34$ (d, J=1.0 Hz, $3 \mathrm{H}), 4.68$ (br.m, $1 \mathrm{H}), 7.24$ (d, $J=8.0 \mathrm{~Hz}, 1 \mathrm{H}), 7.40-7.45(\mathrm{~m}, 1 \mathrm{H}), 7.46-7.52(\mathrm{~m}, 2 \mathrm{H}), 7.57$ $7.61(\mathrm{~m}, 2 \mathrm{H}), 7.63(\mathrm{dd}, J=8.0,2.3 \mathrm{~Hz}, 1 \mathrm{H}) 7.82(\mathrm{~d}, J=2.0 \mathrm{~Hz}, 1$ H). ${ }^{13}$ C NMR $\left(125 \mathrm{MHz}, \mathrm{CDCl}_{3}\right) \delta 13.2\left(\mathrm{CH}_{3}\right), 28.0\left(\underline{\mathrm{CH}}_{3}\right)$, 74.0, 87.1, 119.9, 125.6, 127.0, 127.2, 128.1, 129.0, 129.8, 139.3, 140.8, 147.8, 148.8. LRMS (ES $\left.{ }^{+}\right) \mathrm{C}_{17} \mathrm{H}_{15} \mathrm{NO}_{4} \mathrm{~S}$ requires 329; found $\left(\mathbf{E S}^{+}\right) 352[\mathrm{M}+\mathrm{Na}]^{+}$, (ES) $328[\mathrm{M}-\mathrm{H}]$; HRMS $\left(\mathbf{E S}^{+}\right)$ $\mathrm{C}_{17} \mathrm{H}_{15} \mathrm{NO}_{4} \mathrm{SNa}[\mathrm{M}+\mathrm{Na}]^{+}$requires 352.0614 ; found 352.0617 ( $\Delta=$ $0.85 \mathrm{ppm})$.

\section{1-(4-Methyl-2,2-dioxido-6-phenylbenzo[e][1,2]oxathiin-3-} yl)ethan-1-one, 13d

Colourless, crystalline solid; yield $95 \mathrm{mg}$ (13\%). $\mathbf{R}_{f} 0.52$ (2:8 ethyl acetate: petroleum ether; v/v). ${ }^{\mathbf{1}} \mathbf{H}$ NMR (400 $\mathbf{M H z}, \mathrm{CDCl}_{3}$ ) $\delta 22.50(\mathrm{~s}, 3 \mathrm{H}), 2.61(\mathrm{~s}, 3 \mathrm{H}), 7.32(\mathrm{~d}, J=8.0 \mathrm{~Hz}, 1 \mathrm{H}), 7.34-$ $7.39(\mathrm{~m}, 1 \mathrm{H}), 7.39-7.45(\mathrm{~m}, 2 \mathrm{H}), 7.46-7.50(\mathrm{~m}, 2 \mathrm{H}), 7.68$ $(\mathrm{dd}, J=8.0,2.0 \mathrm{~Hz}, 1 \mathrm{H}), 7.78(\mathrm{~d}, J=2.0 \mathrm{~Hz}, 1 \mathrm{H}) .{ }^{13} \mathbf{C}$ NMR $(100$ $\left.\mathrm{MHz}, \mathrm{CDCl}_{3}\right): \delta=16.7,31.7,119.7,122.1,126.4,127.2,128.3$, 129.2, 132.1, 139.2, 140.1, 146.9, 149.3, 192.7. LRMS (ES $\left.{ }^{+}\right)$ $\mathrm{C}_{17} \mathrm{H}_{14} \mathrm{O}_{4} \mathrm{~S}$ requires 314; found $\left(\mathbf{E S}^{+}\right) 337[\mathrm{M}+\mathrm{Na}]^{+}$, (ES $) 313$ [M-H] ; HRMS $\left(\mathbf{E S}^{+}\right) \mathrm{C}_{17} \mathrm{H}_{15} \mathrm{O}_{4} \mathrm{SNa}[\mathrm{M}+\mathrm{Na}]^{+}$requires 337.0505; found $337.0505,(\Delta=-0.89 \mathrm{ppm})$.

\subsubsection{Reaction of $4 \mathrm{e}$ with $\mathrm{TiCl}_{3}$}

\section{i. Using acetone as solvent:}

According to (GP4) the starting materials were mixed: 4e (312 $\mathrm{mg}, 0.81 \mathrm{mmol}, 1$ eq.), acetone ( $3 \mathrm{~mL}), \mathrm{TiCl}_{3}(1.29 \mathrm{M}$ in $\mathrm{HCl}, 2$ eq., $1.27 \mathrm{~mL}, 1.63 \mathrm{mmol})$. The crude product was purified by preparative HPLC to afford $\mathbf{1 0 b}$ and 21.

\section{4-chloro-3-methylphenyl 3,5-dimethylisoxazole-4-sulfonate, 21}

The title compound was isolated by Preparative HPLC (ACE137-2520, $254 \mathrm{~nm}, \mathrm{n}$-hexane/ ethyl acetate $=90 / 10$, flow rate $=$ $15 \mathrm{~mL} / \mathrm{min}$, retention time $(\mathrm{t})=8.038 \mathrm{~min}$.) as a colourless crystalline solid. Yield $36.57 \mathrm{mg}(15 \%)$. $\mathbf{R}_{\boldsymbol{f}} 0.76$ (2:8 ethyl acetate: petroleum ether; v/v); ${ }^{1} \mathbf{H}$ NMR $\left(400 \mathrm{MHz}, \mathrm{CDCl}_{3}\right) \delta$ 2.38 (s, $3 \mathrm{H}), 2.38$ (s, $3 \mathrm{H}), 2.46$ (s, $3 \mathrm{H}), 6.82$ - 6.87 (m, $1 \mathrm{H})$, 
7.01 (dd, $J=2.0,1.0 \mathrm{~Hz}, 1 \mathrm{H}), 7.34(\mathrm{~d}, J=9.0 \mathrm{~Hz}, 1 \mathrm{H}) .{ }^{13} \mathbf{C} \mathbf{N M R}$ $\left(100 \mathrm{MHz}, \mathrm{CDCl}_{3}\right) \delta 10.7,12.6,20.3,112.2,120.7,124.6,130.2$, 133.6, 138.4, 147.1, 158.0, 175.5. LRMS (ES $\left.{ }^{+}\right) \mathrm{C}_{12} \mathrm{H}_{12} \mathrm{ClNO}_{4} \mathrm{~S}$ requires 301; found $\left(\mathbf{E S}^{+}\right) 302[\mathrm{M}+\mathrm{H}]^{+}$for ${ }^{35} \mathrm{Cl}, 304[\mathrm{M}+\mathrm{H}]^{+}$for ${ }^{37} \mathrm{Cl}, 324[\mathrm{M}+\mathrm{Na}]^{+}$for ${ }^{35} \mathrm{Cl}$; HRMS $\left(\mathbf{E S}^{+}\right) \mathrm{C}_{12} \mathrm{H}_{13} \mathrm{ClNO}_{4} \mathrm{~S}[\mathrm{M}+\mathrm{H}]^{+}$ requires 302.0244; found 302.0245 for ${ }^{35} \mathrm{Cl},(\Delta=0.331 \mathrm{ppm})$. Microanalysis $\mathrm{C}_{12} \mathrm{H}_{12} \mathrm{ClNO}_{4} \mathrm{~S}$ requires: $\mathrm{C}, 47.77 ; \mathrm{H}, 4.01 ; \mathrm{Cl}$, 11.75; N, 4.64; S, $10.63 \%$; Found: C, 47.96, H, 4.32, N, 4.57, S, $10.49, \mathrm{Cl}, 11.30 \%$.

\section{m-Tolyl 3,5-dimethylisoxazole-4-sulfonate, 10b}

The title compound was isolated by preparative HPLC (ACE$137-2520,254 \mathrm{~nm}, \mathrm{n}$-hexane $/$ ethyl acetate $=90 / 10$, flow rate $=$ $15 \mathrm{~mL} / \mathrm{min}$, retention time $(\mathrm{t})=8.721 \mathrm{~min}$.) as a colourless, crystalline solid. Yield $183.82 \mathrm{mg}(85 \%)$. $\mathbf{R}_{f} 0.82$ (2:8 ethyl acetate: petroleum ether; v/v). The spectral data for this compound was identical to that recorded for compound $\mathbf{1 0 b}$, obtained from the reaction of $\mathbf{4 b}$ with $\mathrm{TiCl}_{3}$, experiment 4.4.2.

\section{ii. Using acetone- $d_{6}$ as solvent:}

According to (GP4) the starting materials were mixed: 4e (200 $\mathrm{mg}, 0.52 \mathrm{mmol}, 1$ eq. $)$, acetone- $d_{6}(5 \mathrm{~mL}), \mathrm{TiCl}_{3}(1.29 \mathrm{M}$ in $\mathrm{HCl}$, 2 eq., $0.8 \mathrm{~mL}, 1.03 \mathrm{mmol}$ ).

Examination of the ${ }^{1} \mathrm{H} \mathrm{NMR}$ spectrum (in $\mathrm{CDCl}_{3}$ ) of the crude reaction mixture indicated the presence of $10 \mathrm{~b}$ and $10 \mathbf{b}^{\prime}$ (10b:10b' = 1:1) as the major products.

\subsection{Radical clock experiments}

4.5.1. Synthesis and reactions of 2-(allyloxy)-6-(((3,,5'dimethylisoxazol-4'-yl)sulfonyl)oxy)benzenediazonium tetrafluoroborate, 29 with $\mathrm{TiCl}_{3}$

\section{3-(Allyloxy)-2-nitrophenol}

According to (GP5) the starting materials were mixed: 2nitroresorcinol 26(21 g, $135.38 \mathrm{mmol}, 2$ eq.) and $\mathrm{K}_{2} \mathrm{CO}_{3}(9.31 \mathrm{~g}$, $67.69 \mathrm{mmol}, 2.0$ eq.), $\mathrm{CH}_{3} \mathrm{CN}$ (300 mL), allyl bromide $27(6.43$ $\mathrm{mL}, 74.41 \mathrm{mmol}, 1.1 \mathrm{eq}$.$) . The crude product was purified by$ gradient elution column chromatography (using long silica column, $100 \%$ petroleum ether; to $5: 5 \mathrm{CH}_{2} \mathrm{Cl}_{2}$ : petroleum ether; $\mathrm{v} / \mathrm{v}$ ) to afford 3-(allyloxy)-2-nitrophenol as an orange-coloured, viscous oil. Yield $7.52 \mathrm{~g}(57 \%)$. $\mathbf{R}_{f} 0.57\left(7: 3 \mathrm{CH}_{2} \mathrm{Cl}_{2}\right.$ : petroleum ether; v/v); $\overline{\boldsymbol{v}}_{\text {max }} / \mathbf{c m}^{-1}$ (ATR) 3547-3330, 3089, 3080, 3027, 2988, 2937, 1607, 1586, 1531, 1459, 1424, 1352, 1278, 1256, 1196, 1173, 1110, 1075, 1019, 990, 961, 929, 853, 788, 758. ${ }^{\mathbf{1}} \mathbf{H}$ NMR $\left(400 \mathrm{MHz}, \mathrm{CDCl}_{3}\right) \delta 4.6(\mathrm{dt}, J=5.0,1.0 \mathrm{~Hz}, 2 \mathrm{H}), 5.29(\mathrm{dq}$, $J=10.0,1.0 \mathrm{~Hz}, 1 \mathrm{H}), 5.49(\mathrm{dq}, J=17.0,1.0 \mathrm{~Hz}, 1 \mathrm{H}), 6.00$ (ddt, $J=17.0,10.0,5.0 \mathrm{~Hz}, 1 \mathrm{H}), 6.49(\mathrm{dd}, J=8.0,1.0 \mathrm{~Hz}, 1 \mathrm{H}) 6.62$ $6.65(\mathrm{~m}, 1 \mathrm{H}), 7.30-7.35$ (m, $1 \mathrm{H}), 9.99$ (br. s., $1 \mathrm{H}) .{ }^{13} \mathbf{C} \mathbf{N M R}$ $\left(100 \mathrm{MHz}, \mathrm{CDCl}_{3}\right) \delta 70.1,104.9,110.6,118.0,127.5,131.6$, 135.5, 154.4, 155.11. LRMS (ES $\left.{ }^{+}\right) \mathrm{C}_{9} \mathrm{H}_{9} \mathrm{NO}_{4}$ requires 195; found (ES) $194[\mathrm{M}-\mathrm{H}]^{-}$; HRMS (ES) $\mathrm{C}_{9} \mathrm{H}_{8} \mathrm{NO}_{4}[\mathrm{M}-\mathrm{H}]^{-}$requires 194.0453; found 194.0462 ( $\Delta=4.6 \mathrm{ppm})$.

\section{3-(Allyloxy)-2-nitrophenyl 3,5-dimethylisoxazole-4-sulfonate, 27}

According (GP2), the starting materials were mixed: 1 (1.15 g, $5.90 \mathrm{mmol}, 1.1$ eq.), 3-(allyloxy)-2-nitrophenol (1.05 g, 5.36 mmol, 1 eq.), $\mathrm{Et}_{3} \mathrm{~N}$ (0.82 mL, 5.9 mmol, 1.1 eq.). The title compound, 3-(allyloxy)-2-nitrophenyl 3,5-dimethylisoxazole-4sulfonate, 27 was obtained as a yellow-coloured, crystalline, solid. Yield $1.90 \mathrm{~g}(100 \%)$; mp. $129-130{ }^{\circ} \mathrm{C} ; \mathbf{R}_{f} 0.62(100 \%$ $\left.\mathrm{CH}_{2} \mathrm{Cl}_{2}\right) ; \overline{\boldsymbol{v}}_{\text {max }} / \mathbf{c m}^{-1}$ (ATR) 3099), 2997, 2943, 2877, 1610, 1581, 1533, 1480, 1464, 1408, 1357, 1294, 1272, 1232, 1204, 1126, 1108, 1040, 955, 940, 924, 852, 788. ${ }^{1} \mathbf{H}$ NMR $(400 \mathrm{MHz}$, $\left.\mathrm{CDCl}_{3}\right) \delta 2.28(\mathrm{~s}, 3 \mathrm{H}), 2.51(\mathrm{~s}, 3 \mathrm{H}), 4.63(\mathrm{dt}, J=5.0,1.0 \mathrm{~Hz}, 2$ $\mathrm{H}), 5.27(\mathrm{dq}, J=10.0,1.0 \mathrm{~Hz}, 1 \mathrm{H}), 5.34(\mathrm{dq}, J=17.0,1.0 \mathrm{~Hz}, 1$
H), 5.92 (ddt, $J=17.0,10.0,5.0 \mathrm{~Hz}, 1 \mathrm{H}), 7.03$ (dd, $J=8.0,1.0$ $\mathrm{Hz}, 1 \mathrm{H}), 7.13$ (dd, $J=8.0,1.0 \mathrm{~Hz}, 1 \mathrm{H}), 7.45(\mathrm{t}, J=8.0 \mathrm{~Hz}, 1 \mathrm{H})$. ${ }^{13}$ C NMR $\left(100 \mathrm{MHz}, \mathrm{CDCl}_{3}\right) \delta 10.6,12.7,70.3,111.9,112.9$, $115.0,118.7,131.1,131.5,134.9,140.5,151.1,158.0,176.3$. LRMS (ES $\left.{ }^{+}\right) \quad \mathrm{C}_{14} \mathrm{H}_{14} \mathrm{~N}_{2} \mathrm{O}_{7} \mathrm{~S}$ requires 354; found $\left(\mathbf{E S}^{+}\right) \quad 355$ $[\mathrm{M}+\mathrm{H}]^{+}, 377[\mathrm{M}+\mathrm{Na}]^{+}, 393[\mathrm{M}+\mathrm{K}]^{+}$, (ES ) $353[\mathrm{M}-\mathrm{H}]$; HRMS (ES $\left.{ }^{+}\right) \quad \mathrm{C}_{14} \mathrm{H}_{14} \mathrm{~N}_{2} \mathrm{O}_{7} \mathrm{SNa}[\mathrm{M}+\mathrm{Na}]^{+}$requires 377.0419 ; found $377.0423(\Delta=0.9 \mathrm{ppm})$. Microanalysis $\mathrm{C}_{14} \mathrm{H}_{14} \mathrm{~N}_{2} \mathrm{O}_{7} \mathrm{~S}$ requires: C, 47.46; H, 3.98; N, 7.91; S, 9.05\%; Found: C, 47.31, H, 3.97, N, 7.77, S, $9.05 \%$.

\section{3-(Allyloxy)-2-aminophenyl 3,5-dimethylisoxazole-4-sulfonate, 28}

According (GP6), the starting materials were mixed: 3(allyloxy)-2-nitrophenyl 3,5-dimethylisoxazole-4-sulfonate 27 (1.95 g, $5.50 \mathrm{mmol}, 1$ eq.), zinc dust (1.8 g, $27.54 \mathrm{mmol}, 5$ eq.), $\mathrm{MeOH} / \mathrm{THF}(1: 1,25 \mathrm{~mL})$ and saturated $\mathrm{NH}_{4} \mathrm{Cl}(25 \mathrm{~mL})$ was added. The title compound, 3--(allyloxy)-2-aminophenyl 3,5dimethylisoxazole-4-sulfonate, $\mathbf{2 8}$ was obtained as colourless oil and was pure enough (judged by: ${ }^{1} \mathrm{H}$ NMR spectra, and TLC), and directly used for next reaction without any further purification. Yield $1.74 \mathrm{~g}(98 \%)$. $\mathbf{R}_{f} 0.45\left(100 \% \mathrm{CH}_{2} \mathrm{Cl}_{2}\right)$; $\overline{\boldsymbol{v}}_{\max } / \mathbf{c m}^{-1}$ (ATR) 3472, 3382, 3084, 2981, 2939, 2870, 1619, 1587, 1497, 1471, 1408), 1384, 1360, 1114, 1288, 1269, 1223, 1201, 1162, 1078, 1033, 920, 789, 770. ${ }^{\mathbf{1}} \mathbf{H}$ NMR $(400 \mathrm{MHz}$, $\left.\mathrm{CDCl}_{3}\right) \delta 2.23(\mathrm{~s}, 3 \mathrm{H}), 2.35$ (s, $\left.3 \mathrm{H}\right), 3.95$ (br. s., $2 \mathrm{H}$ ), 4.46 (dt, $J=5.0,1.0 \mathrm{~Hz}, 2 \mathrm{H}), 5.20(\mathrm{dq}, J=10.0,1.0 \mathrm{~Hz}, 1 \mathrm{H}), 5.29(\mathrm{dq}$, $J=17.0,1.0 \mathrm{~Hz}, 1 \mathrm{H}), 5.94$ (ddt, $J=17.0,10.0,5.0 \mathrm{~Hz}, 1 \mathrm{H}), 6.43$ $6.52(\mathrm{~m}, 2 \mathrm{H}) 6.63(\mathrm{dd}, J=7.8,1.0 \mathrm{~Hz}, 1 \mathrm{H}) .{ }^{13} \mathbf{C}$ NMR $(100$ $\left.\mathrm{MHz}, \mathrm{CDCl}_{3}\right): \delta=10.6,12.5,69.5,110.6,112.2,115.0,116.4$, 117.8, 130.8, 132.9, 135.9, 147.3, 158.1, 175.7. LRMS (ES ${ }^{+}$ $\mathrm{C}_{14} \mathrm{H}_{16} \mathrm{~N}_{2} \mathrm{O}_{5} \mathrm{~S}$ requires 324; found $\left(\mathbf{E S}^{+}\right) 325[\mathrm{M}+\mathrm{H}]^{+}, 347$ $[\mathrm{M}+\mathrm{Na}]^{+}$; HRMS (ES $\left.{ }^{+}\right) \quad \mathrm{C}_{14} \mathrm{H}_{16} \mathrm{~N}_{2} \mathrm{O}_{5} \mathrm{SNa} \quad[\mathrm{M}+\mathrm{Na}]^{+}$requires 347.0678; found 347.0688 ( $\Delta=3 \mathrm{ppm})$.

\section{2-(Allyloxy)-6-(((3',5'-dimethylisoxazol-4'-yl)sulfonyl)oxy)- benzenediazonium tetrafluoroborate, 29}

According to (GP3) the starting materials were mixed: 28 (473 $\mathrm{mg}, 1.45 \mathrm{mmol}, 1$ eq. $)$, ethanol $(5 \mathrm{~mL})$, isoamyl nitrite $(0.23 \mathrm{~mL}$, $1.74 \mathrm{mmol}, 1.2$ eq.), $\mathrm{HBF}_{4} 48 \%$ (0.49 mL, $3.79 \mathrm{mmol}, 2.6$ eq.). The title compound, 2-(allyloxy)-6-(((3',5'-dimethylisoxazol-4'yl)sulfonyl)oxy)benzenediazonium tetrafluoroborate 29 was obtained as colourless, crystalline, solid. Yield $583 \mathrm{mg}$ (95\%); $\overline{\boldsymbol{v}}_{\max } / \mathbf{c m}^{-1}$ (ATR) 3099, 2985, 2944, 2249, 1600, 1570, 1490, 1450, 1408, 1397, 1381, 1363, 1306, 1263, 1210, 1132, 1099, 1051, 948, 927, 792, 744, 702, 677. ${ }^{\mathbf{1}} \mathbf{H}$ NMR $(400 \mathrm{MHz}$, acetone-d $\left.\mathrm{d}_{6}\right) \delta 2.46(\mathrm{~s}, 3 \mathrm{H}), 2.74(\mathrm{~s}, 3 \mathrm{H}), 5.22(\mathrm{dt}, J=5,1 \mathrm{~Hz}, 2$ H), $5.46(\mathrm{dq}, J=10,1 \mathrm{~Hz}, 1 \mathrm{H}), 5.62(\mathrm{dq}, J=17,1 \mathrm{~Hz}, 1 \mathrm{H}), 6.11$ $6.24(\mathrm{~m}, 1 \mathrm{H}), 7.51(\mathrm{dd}, J=8.6,1 \mathrm{~Hz}, 1 \mathrm{H}), 7.76(\mathrm{~d}, J=9 \mathrm{~Hz}, 1 \mathrm{H})$, 8.41 (dd, $J=9,8 \mathrm{~Hz}, 1 \mathrm{H}) .{ }^{13}$ CNMR $\left(100 \mathrm{MHz}\right.$, acetone-d $\left.{ }_{6}\right) \delta$ 9.9, 12., 73.3, 110.6, 114.2, 114.91, 120.1, 130.5, 145.8, 148.1, 157.8, 161.8, 164.3, 178.5. Microanalysis for $\mathrm{C}_{14} \mathrm{H}_{14} \mathrm{BF}_{4} \mathrm{~N}_{3} \mathrm{O}_{5} \mathrm{~S}$, require: C, 39.74; H, 3.34; N, 9.93; S, $7.58 \%$; Found: C, 39.76, $\mathrm{H}, 3.17, \mathrm{~N}, 9.81, \mathrm{~S}, 7.76 \%$.

\subsubsection{Reaction of 29 with $\mathrm{TiCl}_{3}$}

According to (GP4) the starting materials were mixed: 29 (466 $\mathrm{mg}, 1.10 \mathrm{mmol}, 1$ eq.), acetone ( $5 \mathrm{~mL}), \mathrm{TiCl}_{3}(1.29 \mathrm{M}$ in $\mathrm{HCl}, 2$ eq., $1.7 \mathrm{~mL}, 2.2 \mathrm{mmol})$. Purification of the crude reaction mixture by reparative HPLC afforded 28, 30, 31 and $\mathbf{3 2}$

3-Methylbenzofuran-4-yl 3',5'-dimethylisoxazole-4'-sulfonate, 30

Purified by Preparative HPLC (ACE-137-2520, 254 nm, nhexane/ ethyl acetate $=90 / 10$, flow rate $=15 \mathrm{~mL} / \mathrm{min}$, retention time $(\mathrm{t})=9.180 \mathrm{~min}$.). The title compound was obtained as a colourless, crystalline, solid. Yield $10 \mathrm{mg}(3 \%)$. ${ }^{1}$ H NMR (400 
$\left.\mathrm{MHz}, \mathrm{CDCl}_{3}\right) \delta 2.28(\mathrm{~s}, 3 \mathrm{H}), 2.29(\mathrm{~d}, J=1.0 \mathrm{~Hz}, 3 \mathrm{H}), 2.35$ (s, $3 \mathrm{H}), 6.58$ - $6.60(\mathrm{~m}, 1 \mathrm{H}), 7.07$ - $7.12(\mathrm{~m}, 1 \mathrm{H}), 7.33$ - 7.37 (m, 2 H). LRMS (ES $\left.{ }^{+}\right) \mathrm{C}_{14} \mathrm{H}_{13} \mathrm{NO}_{5} \mathrm{~S}$ requires 307; found $\left(\mathbf{E S}^{+}\right) 330$ $[\mathrm{M}+\mathrm{Na}]^{+} ; \quad$ HRMS $\left(\mathbf{E S}^{+}\right) \quad \mathrm{C}_{14} \mathrm{H}_{13} \mathrm{NO}_{5} \mathrm{~S} \quad[\mathrm{M}+\mathrm{Na}]^{+}$requires 330.0412 ; found 330.0410 ( $\Delta=0.605 \mathrm{ppm})$.

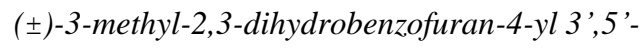

dimethylisoxazole-4'-sulfonate, 31

Purified by Preparative HPLC (ACE-137-2520, 254 nm, nhexane/ ethyl acetate $=90 / 10$, flow rate $=15 \mathrm{~mL} / \mathrm{min}$, retention time $(\mathrm{t})=10.599 \mathrm{~min}$.) gave the title compound as a colourless, crystalline, solid. Yield $95 \mathrm{mg}(28 \%)$. $\mathbf{R}_{f} 0.62$ (3:7 ethyl acetate: petroleum ether; v/v). ${ }^{1} \mathbf{H}$ NMR $\left(400 \mathrm{MHz}, \mathrm{CDCl}_{3}\right): \delta=1.30(\mathrm{~d}$, $J=7 \mathrm{~Hz}, 3 \mathrm{H}), 2.29$ (s, $3 \mathrm{H}), 2.37$ (s, $3 \mathrm{H}), 3.53(\mathrm{dt}, J=9.0,6.7 \mathrm{~Hz}$, $1 \mathrm{H}), 4.07$ (dd, $J=9.0,6.3 \mathrm{~Hz}, 1 \mathrm{H}), 4.59$ (t, $J=9.0 \mathrm{~Hz}, 1 \mathrm{H}), 6.31$ $(\mathrm{dd}, J=8.0,1.0 \mathrm{~Hz}, 1 \mathrm{H}), 6.67(\mathrm{~d}, J=8.0 \mathrm{~Hz}, 1 \mathrm{H}), 6.91-7.07(\mathrm{~m}$, $1 \mathrm{H}) .{ }^{13} \mathrm{C}$ NMR $\left(100 \mathrm{MHz}, \mathrm{CDCl}_{3}\right): \delta=10.7\left(\mathrm{CH}_{3}\right), 12.6\left(\mathrm{CH}_{3}\right)$, $18.5\left(\mathrm{CH}_{3}\right), 35.9,78.9,109.2,112.9,113.9,125.7,129.4,145.9$, 158.1, 161.9, 175.4. LRMS (ES $\left.{ }^{+}\right) \mathrm{C}_{14} \mathrm{H}_{15} \mathrm{NO}_{5} \mathrm{~S}$ requires 309; found $\left(\mathbf{E S}^{+}\right) 310[\mathrm{M}+\mathrm{H}]^{+}$; HRMS (ES $\left.{ }^{+}\right) \mathrm{C}_{14} \mathrm{H}_{16} \mathrm{NO}_{5} \mathrm{~S}[\mathrm{M}+\mathrm{H}]^{+}$ requires 310.0732; found $310.0744(\Delta=-3.77 \mathrm{ppm})$.

(士)-3-(Chloromethyl)-2,3-dihydrobenzofuran-4-yl 3,,5'-

dimethylisoxazole-4'-sulfonate, 32

Purified by Preparative HPLC (ACE-137-2520, 254 nm, nhexane/ ethyl acetate $=90 / 10$, flow rate $=15 \mathrm{~mL} / \mathrm{min}$, retention time $(\mathrm{t})=12.411 \mathrm{~min}$.) gave the title compound as a colourless, crystalline, solid; Yield $64 \mathrm{mg}(17 \%)$. $\mathbf{R}_{f} 0.56$ (3:7 ethyl acetate: petroleum ether; v/v). ${ }^{1} \mathbf{H}$ NMR $\left(400 \mathrm{MHz} \mathrm{CDCl}_{3}\right) \delta 12.39(\mathrm{~s}, 3$ H), 2.49 (s, $3 \mathrm{H}), 3.68(\mathrm{dd}, J=11.0,9.0 \mathrm{~Hz}, 1 \mathrm{H}), 3.92$ - $4.04(\mathrm{~m}, 2$ $\mathrm{H}), 4.61-4.73(\mathrm{~m}, 2 \mathrm{H}), 6.40(\mathrm{dd}, J=8.0,1.0 \mathrm{~Hz}, 1 \mathrm{H}), 6.80(\mathrm{~d}$, $J=8.0 \mathrm{~Hz}, 1 \mathrm{H}) 7.13-7.19(\mathrm{~m}, 1 \mathrm{H}) .{ }^{13} \mathbf{C}$ NMR $(100 \mathrm{MHz}$, $\left.\mathrm{CDCl}_{3}\right) \delta 10.7,12.6,43.8,44.6,75.3,109.7,112.6,113.9,120.5$, 130.7, 145.9, 158.1, 162.6, 175.7. LRMS (ES $\left.{ }^{+}\right) \mathrm{C}_{14} \mathrm{H}_{14} \mathrm{ClNO}_{5} \mathrm{~S}$ requires 343; found $\left(\mathbf{E S}^{+}\right) 344[\mathrm{M}+\mathrm{H}]^{+}, 308$ [M-Cl] ; HRMS $\left(\mathbf{E S}^{+}\right) \mathrm{C}_{14} \mathrm{H}_{14} \mathrm{NO}_{5} \mathrm{~S}$ [M- Cl] ${ }^{-}$requires 308.0587; found 308.0583 $(\Delta=-1.36 \mathrm{ppm})$.

\section{3-(Allyloxy)-2-aminophenyl 3,5-dimethylisoxazole-4-sulfonate, 28}

Purified by Preparative HPLC (ACE-137-2520, 254 nm, nhexane/ ethyl acetate $=90 / 10$, flow rate $=15 \mathrm{~mL} / \mathrm{min}$, retention time $(\mathrm{t})=17.208 \mathrm{~min}$.) gavr the title compound as a colourless oil; Yield $146 \mathrm{mg}(41 \%)$. ${ }^{1} \mathbf{H}$ NMR $\left(400 \mathrm{MHz}, \mathrm{CDCl}_{3}\right) \delta 2.27$ (s, $3 \mathrm{H}), 2.38$ (s, $3 \mathrm{H}), 3.94$ (br. s., $2 \mathrm{H}), 4.48$ (dt, J=5.0, $1 \mathrm{~Hz}, 2$ H), $5.23(\mathrm{dq}, J=10.0,1.0 \mathrm{~Hz}, 1 \mathrm{H}), 5.31(\mathrm{dq}, J=17.0,1.0 \mathrm{~Hz}, 1$ H), 5.91 - $6.02(\mathrm{~m}, 1 \mathrm{H}) 6.44-6.47(\mathrm{~m}, 1 \mathrm{H}), 6.49-6.54(\mathrm{~m}, 1 \mathrm{H})$ $6.64(\mathrm{dd}, J=8.0,1.0 \mathrm{~Hz}, 1 \mathrm{H}) .{ }^{13} \mathbf{C}$ NMR $\left(100 \mathrm{MHz}, \mathrm{CDCl}_{3}\right) \delta$ $10.7\left(\mathrm{CH}_{3}\right), 12.6\left(\mathrm{CH}_{3}\right), 69.7,110.7,112.4,115.0,116.6,118.1$,

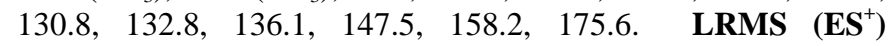
$\mathrm{C}_{14} \mathrm{H}_{16} \mathrm{~N}_{2} \mathrm{O}_{5} \mathrm{~S}$ requires 324; found $\left(\mathbf{E S}^{+}\right) 325[\mathrm{M}+\mathrm{H}]^{+}, 347$ $[\mathrm{M}+\mathrm{Na}]^{+}$; HRMS (ES $\left.{ }^{+}\right) \mathrm{C}_{14} \mathrm{H}_{16} \mathrm{~N}_{2} \mathrm{O}_{5} \mathrm{SNa} \quad[\mathrm{M}+\mathrm{Na}]^{+}$requires 347.0678; found 347.0685 ( $\Delta=2 \mathrm{ppm})$. The spectral data for this compound was identical to that observed earlier for $\mathbf{2 8}$.

4.5.3. Itramolecular radical clock reactions: reaction of 1,3bis(allyloxy)benzenediazonium tetrafluoroborate, 36 with $\mathrm{TiCl}_{3}$

\section{Synthesis of 1,3-bis(allyloxy)-2-nitrobenzene}

According to (GP5), and after separation of 3-(allyloxy)-2nitrophenol 28. The crude mixture of unreacted 2-nitroresorcinol and 1,3-bis(allyloxy)-2-nitrobenzene was stirred overnight with excess $\mathrm{NaOH}(2 \mathrm{M}, 100 \mathrm{~mL})$ and the mixture was extracted by $\mathrm{CH}_{2} \mathrm{Cl}_{2}$ (50 mL x 3). The organic layer was washed with brine, dried over $\mathrm{MgSO}_{4}$ and concentrated in vacuo. The title compound was isolated as a yellowish green oil. Yield $5 \mathrm{~g}(29 \%)$. $\mathbf{R}_{f} 0.70$ (5:5 $\mathrm{CH}_{2} \mathrm{Cl}_{2}$ : petroleum ether; v/v); $\overline{\boldsymbol{v}}_{\text {max }} / \mathbf{c m}^{-1}$ (ATR) 3097, 3087, 3019, 2990, 2938, 2886, 2874, 1649, 1610, 1584, 1530, 1477, 1423, 1370, 1303, 1262, 1237, 1117, 1092, 987, 927, 850, 775, 669. ${ }^{1} \mathbf{H}$ NMR $\left(400 \mathrm{MHz}, \mathrm{CDCl}_{3}\right) \delta 4.4(\mathrm{dt}, J=5,1 \mathrm{~Hz}, 4 \mathrm{H})$, 5.09 (dq, $J=10,1 \mathrm{~Hz}, 2 \mathrm{H}), 5.21$ (dq, $J=17,1 \mathrm{~Hz}, 2 \mathrm{H}$ ), 5.78 (ddt, $J=17,10,5,5 \mathrm{~Hz}, 2 \mathrm{H}), 6.47(\mathrm{~d}, J=1 \mathrm{~Hz}, 2 \mathrm{H}), 7.10(\mathrm{t}, J=8 \mathrm{~Hz}, 1$ $\mathrm{H}) .{ }^{13} \mathrm{C}$ NMR $\left(100 \mathrm{MHz}, \mathrm{CDCl}_{3}\right) \delta 69.7,105.9,118.0(2 \mathrm{x}$ $=\underline{\mathrm{CH}}), 131.1,131.8,132.6,150.7$. LRMS $\left(\mathbf{E S}^{+}\right) \mathrm{C}_{12} \mathrm{H}_{13} \mathrm{NO}_{4}$ requires 235; found $\left(\mathbf{E S}^{+}\right) 236[\mathrm{M}+\mathrm{H}]^{+}, 258[\mathrm{M}+\mathrm{Na}]^{+}, 274[\mathrm{M}+$ $\mathrm{K}]^{+}$; HRMS (EI) $\mathrm{C}_{12} \mathrm{H}_{13} \mathrm{NO}_{4}\left[\mathrm{M}^{+}\right]$requires 235.0839; found $235.0841(\Delta=0.81 \mathrm{ppm})$.

Synthesis of: 1,3-bis(allyloxy)aniline, 37

According (GP6), the starting materials were mixed: 1,3bis(allyloxy)-2-nitrobenzene 35 (1.025 g, $4.35 \mathrm{mmol}, 1$ eq.), zinc dust (1.42 g, $21.78 \mathrm{mmol}, 5$ eq.), MeOH / THF (1:1, $8 \mathrm{~mL}$ ) and saturated $\mathrm{NH}_{4} \mathrm{Cl}(8 \mathrm{~mL})$ was added. The title amine was obtained as brown oil, was pure enough (judged by: NMR spectra, and TLC), and directly used for next reaction without any further purification. Yield $840 \mathrm{mg}(94 \%)$. $\mathbf{R}_{f} 0.68\left(100 \% \mathrm{CH}_{2} \mathrm{Cl}_{2}\right) ; \overline{\boldsymbol{v}}_{\text {max }}$ /cm ${ }^{-1}$ (ATR) 3471, 3372, 3080, 3016, 2981, 2920, 2911, 2864, 1648, 1599, 1566, 1422, 1362, 1291, 1175, 1139, 1047, 990, 920, 757, 713. ${ }^{1} \mathbf{H}$ NMR $\left(400 \mathrm{MHz}, \mathrm{CDCl}_{3}\right) \delta 3.71$ (br. s., $\left.2 \mathrm{H}\right), 4.40$ (dt, $J=5,1 \mathrm{~Hz}, 4 \mathrm{H}), 5.12(\mathrm{dq}, J=11.0,1.0 \mathrm{~Hz}, 2 \mathrm{H}), 5.26$ (dq, $J=17,1 \mathrm{~Hz}, 2 \mathrm{H}), 5.87$ - 5.99 (m, $2 \mathrm{H}), 6.35$ - 6.40 (m, $2 \mathrm{H}), 6.46$ - $6.51(\mathrm{~m}, 1 \mathrm{H}) .{ }^{13} \mathbf{C}$ NMR $\left(100 \mathrm{MHz}, \mathrm{CDCl}_{3}\right) \delta$ 69.5, 105.9, 116.7, 117.3, 126.4, 133.8, 146.6. LRMS (ES $\left.{ }^{+}\right) \mathrm{C}_{12} \mathrm{H}_{15} \mathrm{NO}_{2}$ requires 205; found $\left(\mathbf{E S}^{+}\right) 206[\mathrm{M}+\mathrm{H}]^{+}$; HRMS (EI) $\mathrm{C}_{12} \mathrm{H}_{16} \mathrm{NO}_{2}$ $\left[\mathrm{M}^{+}\right]$requires 205.1097; found $205.1097(\Delta=0 \mathrm{ppm})$.

\section{Synthesis of 1,3-bis(allyloxy)benzenediazoniumtetrafluoro- borate, 36}

According to (GP3) the starting materials were mixed: 2,6bis(allyloxy)aniline 36 (319 mg, $1.56 \mathrm{mmol}, 1$ eq.), ethanol (4 $\mathrm{mL})$, isoamyl nitrite $(0.25 \mathrm{~mL}, 1.87 \mathrm{mmol}, 1.2$ eq. $), \mathrm{HBF}_{4} 48 \%$ ( $0.53 \mathrm{~mL}, 4.05 \mathrm{mmol}, 2.6$ eq.). The title compound was obtained as yellow solid. Yield $421 \mathrm{mg}(89 \%) ; \overline{\boldsymbol{v}}_{\text {max }} / \mathbf{c m}^{-1}$ (ATR) 3176 , 3105, 3025, 2962, 2272, 2243, 1579, 1490, 1466, 1426), 1319, 1272, 1246, 1136, 1033, 995, 933, 888, 788, 714, 653, 623, 520. ${ }^{1} \mathbf{H}$ NMR (400 MHz, acetone-d 6 ) $\delta 4.59(\mathrm{dt}, J=5,1 \mathrm{~Hz}, 4 \mathrm{H}), 4.97$ (dq, $J=10,1 \mathrm{~Hz}, 2 \mathrm{H}), 5.09$ (dq, $J=17,1 \mathrm{~Hz}, 2 \mathrm{H}), 5.64$ (ddt, $J=17,10,5,5 \mathrm{~Hz}, 2 \mathrm{H}), 6.70(\mathrm{~d}, J=1 \mathrm{~Hz}, 2 \mathrm{H}), 7.71(\mathrm{t}, J=8 \mathrm{~Hz}, 1$ H). ${ }^{13}$ C NMR (100 MHz, $\left.\mathrm{CDCl}_{3}\right) \delta 71.8,92.2,106.8,119.8$, 131.0, 145.2, 160.8. Microanalysis for $\mathrm{C}_{12} \mathrm{H}_{13} \mathrm{BF}_{4} \mathrm{~N}_{2} \mathrm{O}_{2}$, require: C, 47.40; H, 4.31; N, 9.21 \%; Found: C, 46.63, H, 4.12, N, 9.05 $\%$.

\subsection{Reaction of 36 with $\mathrm{TiCl}_{3}$ leading to 37 and 38}

According to (GP4) the starting materials were mixed: 37 (300 $\mathrm{mg}, 0.986 \mathrm{mmol}, 1$ eq.), acetone ( $4 \mathrm{~mL}), \mathrm{TiCl}_{3}(1.29 \mathrm{M}$ in $\mathrm{HCl}, 2$ eq., $1.5 \mathrm{~mL}, 1.97 \mathrm{mmol})$. Purification of the crude reaction mixture by column chromatography $\left(6: 4 \mathrm{CH}_{2} \mathrm{Cl}_{2}\right.$ : hexane; v/v) and afforded $\mathbf{3 7}$ and $\mathbf{3 8}$.

(士)-6-(Allyloxy)-3'-(chloromethyl)-2 ',3'-dihydrobenzofuran, 38

Colourless, crystalline, solid. Yield $20 \mathrm{mg}(9 \%) . \mathbf{R}_{f} 0.35$ (6:4 $\mathrm{CH}_{2} \mathrm{Cl}_{2}$ : hexane; v/v). ${ }^{1} \mathbf{H}$ NMR $\left(400 \mathrm{MHz}, \mathrm{CDCl}_{3}\right) \delta 3.59$ (dd, $J=10.0,11.0 \mathrm{~Hz}, 1 \mathrm{H}), 3.92-4.00(\mathrm{~m}, 1 \mathrm{H}), 4.04$ (ddd, $J=10.0,3.0$, $1.0 \mathrm{~Hz}, 1 \mathrm{H}), 4.59$ (dt, $J=5.0,1.0 \mathrm{~Hz}, 2 \mathrm{H}), 4.63$ (dd, $J=10.0,5.0$ $\mathrm{Hz}, 1 \mathrm{H}), 4.66$ (dd, $J=10.0,9.0 \mathrm{~Hz}, 1 \mathrm{H}), 5.32$ (dq, $J=10.0,1.0$ $\mathrm{Hz}, 1 \mathrm{H}), 5.41(\mathrm{dq}, J=17.0,1.0 \mathrm{~Hz}, 1 \mathrm{H}), 6.04-6.06(\mathrm{~m}, 1 \mathrm{H}), 6.42$ $(\mathrm{d}, J=8.0 \mathrm{~Hz}, 1 \mathrm{H}), 6.48(\mathrm{~d}, J=8.0 \mathrm{~Hz}, 1 \mathrm{H}), 7.13(\mathrm{t}, J=8.0 \mathrm{~Hz}, 1$ H). ${ }^{13}$ C NMR $\left(100 \mathrm{MHz}, \mathrm{CDCl}_{3}\right) \delta 43.6,45.4,68.7,75.2,103.3$, 104.1, 117.6, 130.5, 133.0. LRMS (ES $\left.{ }^{+}\right) \mathrm{C}_{12} \mathrm{H}_{13} \mathrm{ClO}_{2}$ requires 224; found GC-MS (EI): $224[\mathrm{M}]^{+.}$for ${ }^{35} \mathrm{Cl}$; HRMS (EI); 
$\mathrm{C}_{12} \mathrm{H}_{14} \mathrm{ClO}_{2}[\mathrm{M}]^{+.}$requires 224.0598 for ${ }^{35} \mathrm{Cl}$; found $224.0593(\Delta$ $=-2.23 \mathrm{ppm}$ ).

\section{1,3-Bis(allyloxy)aniline, 37}

Brown-coloured oil. Yield $151 \mathrm{mg}$ (75\%). $\mathbf{R}_{f} 0.68(100 \%$ $\mathrm{CH}_{2} \mathrm{Cl}_{2}$ ). ${ }^{1} \mathbf{H}$ NMR (400 MHz, $\mathrm{CDCl}_{3}$ ): $\delta=3.73$ (br. s., $2 \mathrm{H}$ ), 4.41 $(\mathrm{dt}, J=5.0,1.0 \mathrm{~Hz}, 4 \mathrm{H}), 5.10(\mathrm{dq}, J=11.0,1.0 \mathrm{~Hz}, 2 \mathrm{H}), 5.28(\mathrm{dq}$, $J=17.0,1.0 \mathrm{~Hz}, 2 \mathrm{H}), 5.88-6.00(\mathrm{~m}, 2 \mathrm{H}), 6.36-6.41(\mathrm{~m}, 2 \mathrm{H})$, $6.48-6.53(\mathrm{~m}, 1 \mathrm{H}) .{ }^{13} \mathrm{C}$ NMR $\left(100 \mathrm{MHz}, \mathrm{CDCl}_{3}\right) \delta 69.6,105.8$, 116.9, 117.4, 126.4, 133.7, 146.7. LRMS Calculated $\mathrm{C}_{12} \mathrm{H}_{15} \mathrm{NO}_{2}$, 205, observed LRMS $\left(\mathbf{E S}^{+}\right) 206[\mathrm{M}+\mathrm{H}]^{+}$. The spectral data for this compound was identical to that previouslyfor this compound.

4.7 Intermolecular vs Intramolecular radical capture experiments: reaction of $4 \mathrm{~b}$ with $\mathrm{TiCl}_{3}$ in the presence of furan

To a solution of 2-(((3',5'-dimethylisoxazol-4-yl)sulfonyl)oxy)6-methylbenzenediazonium tetrafluoroborate $4 \mathbf{b}(435 \mathrm{mg}, 1.36$ mmol, 1 eq.) in acetone $(5 \mathrm{ml})$ containing furan $(0.5 \mathrm{~mL}, 6.84$ mmol, 5 eq.) was added $\mathrm{TiCl}_{3}(2.1 \mathrm{~mL}, 2.72 \mathrm{mmol}, 2$ eq.) using our standard procedure (GP4).

Purification of the crude product by flash column chromatography and then HPLC afforded $\mathbf{1 0 b}, \mathbf{1 2 b}$, and 25.

2-(Furan-2'-yl)-3-methylphenyl 3',,5',-dimethylisoxazole-4',sulfonate, 25

Purified by Prep HPLC (ACE-137-2520, 254 nm, n-hexane/ ethyl acetate $=90 / 10$, flow rate $=15 \mathrm{~mL} / \mathrm{min}$, retention time $(\mathrm{t})=$ 9.355 min.) to give title compound as a pale yellow crystal. Yield $181 \mathrm{mg}$ (40 \%); mp. 88-90; $\mathbf{R}_{f} 0.69$ (3:7 ethyl acetate: petroleum ether; v/v). ${ }^{1} \mathbf{H}$ NMR $\left(400 \mathrm{MHz}, \mathrm{CDCl}_{3}\right) \delta 1.91(\mathrm{~s}, 3 \mathrm{H}), 2.12(\mathrm{~s}$, $3 \mathrm{H}), 2.16$ (s, $3 \mathrm{H}), 6.28$ (dd, J=3.0, $1.0 \mathrm{~Hz}, 1 \mathrm{H}), 6.35$ (dd, $J=3.0$, $2.0 \mathrm{~Hz}, 1 \mathrm{H}), 7.14-7.18(\mathrm{~m}, 1 \mathrm{H}), 7.25-7.27$ (m, $2 \mathrm{H}), 7.33$ (dd, $J=2.0,1.0 \mathrm{~Hz}, 1 \mathrm{H}) .{ }^{13} \mathrm{C}$ NMR $\left(100 \mathrm{MHz}, \mathrm{CDCl}_{3}\right) \delta 10.5,12.4$, 20.6, 110.7, 111.2, 112.4, 121.5, 125, 129.4, 129.8, 140.6, 142.9, 146.8, 147.2, 157.8, 174.9. LRMS (ES $\left.{ }^{+}\right) \mathrm{C}_{16} \mathrm{H}_{15} \mathrm{NO}_{5} \mathrm{~S}$ requires 333; found $\left(\mathbf{E S}^{+}\right) 334[\mathrm{M}+\mathrm{H}]^{+}, 356[\mathrm{M}+\mathrm{Na}]^{+}$; HRMS $\left(\mathbf{E S}^{+}\right)$ $\mathrm{C}_{16} \mathrm{H}_{16} \mathrm{NO}_{5} \mathrm{SNa}[\mathrm{M}+\mathrm{Na}]^{+}$requires 356.0563; found $356.0562(\Delta=$ - $0.32 \mathrm{ppm}$ ).

m-Tolyl 3,5-dimethylisoxazole-4-sulfonate, 10b

Purified by Prep HPLC (ACE-137-2520, 254 nm, n-hexane/ ethyl acetate $=90 / 10$, flow rate $=15 \mathrm{~mL} / \mathrm{min}$, retention time $(\mathrm{t})=$ $8.851 \mathrm{~min}$.) to afford title compound as a colourless, crystalline solid. Yield $109 \mathrm{mg}(30 \%)$. The spectral data for this compound was identical to that recorded for compound $\mathbf{1 0 b}$ obtained from the reaction between $\mathbf{4 b}$ and $\mathrm{TiCl}_{3}$, experiment 4.4.2.

$\left(3 a R^{*}, 9 b R^{*}\right)-3,9,9 b$-trimethyl-3a,9b-

dihydrobenzo[5,6][1,2] oxathiino[3,4-d]isoxazole-4,4-dioxide, 12b

Purified by column chromatography to give title compound as a white solid; Yield $25 \mathrm{mg}(7 \%)$. $\quad \mathbf{R}_{f} 0.45$ (3:7 ethyl acetate: petroleum ether; v/v). ${ }^{1} \mathbf{H}$ NMR $\left(400 \mathrm{MHz}, \mathrm{CDCl}_{3}\right) \delta 1.84$ (s, 3 H), $2.33(\mathrm{~d}, J=1 \mathrm{~Hz}, 3 \mathrm{H}), 2.68$ (s, $3 \mathrm{H}), 4.65$ (br.m, $1 \mathrm{H}), 7.00$ $7.04(\mathrm{~m}, 1 \mathrm{H}), 7.18$ - $7.22(\mathrm{~m}, 1 \mathrm{H}), 7.28-7.33$ (m, $12 \mathrm{H})$. LRMS (ES ${ }^{+}$) $\mathrm{C}_{12} \mathrm{H}_{13} \mathrm{NO}_{4} \mathrm{~S}$ requires 267; found (ES ${ }^{+}$) 268; HRMS (EI) $\mathrm{C}_{12} \mathrm{H}_{13} \mathrm{NO}_{4} \mathrm{~S}\left[\mathrm{M}^{+}\right]$requires 267.0463 ; found 267.0474, $(\Delta=4.11$ $\mathrm{ppm}$ ). The spectral data for this compound was identical to that previously recorded for $\mathbf{1 2 b}$.

Synthesis of 2-(3',5'-dimethylisoxazol-4'-yl)-3-methylphenol, $\mathbf{8 b}$

Purified by column chromatography afforded the title compound as a white crystal; Yield $60 \mathrm{mg}(22 \%)$. $\mathbf{R}_{f} 0.25$ (3:7 ethyl acetate: petroleum ether; v/v). ${ }^{1} \mathbf{H}$ NMR $\left(400 \mathrm{MHz}, \mathrm{CDCl}_{3}\right) \delta 1.96(\mathrm{~s}$, $3 \mathrm{H}), 1.99$ (s, $3 \mathrm{H}), 2.16(\mathrm{~s}, 3 \mathrm{H}), 5.81(\mathrm{~s}, 1 \mathrm{H}), 6.75-6.79$ (m, 2 $\mathrm{H}), 7.12(\mathrm{t}, J=8.0 \mathrm{~Hz}, 1 \mathrm{H}) .{ }^{13} \mathbf{C}$ NMR $\left(100 \mathrm{MHz}, \mathrm{CDCl}_{3}\right) \delta 10.5$, $11.5,20.0,110.3,113.2,115.1,121.9,129.7,139.2,154.8,160.4$, 167.4. LRMS (ES $\left.{ }^{+}\right) \mathrm{C}_{12} \mathrm{H}_{13} \mathrm{NO}_{2}$ requires 203; found $\left(\mathbf{E S}^{+}\right) 204$ $[\mathrm{M}+\mathrm{H}]^{+},\left(\mathbf{E S}^{-}\right) 202[\mathrm{M}-\mathrm{H}]$; HRMS $\left(\mathbf{E S}^{+}\right) \mathrm{C}_{12} \mathrm{H}_{14} \mathrm{NO}_{2}[\mathrm{M}+\mathrm{H}]^{+}$ requires 204.1025; found $204.1029,(\Delta=1.95 \mathrm{ppm})$. The spectral data for this compound was identical to a sample of $\mathbf{8 b}$ previously prepared in experiments 4.4.2 and 4.6.

\subsection{Attempted fluoride-mediated Truce-Smiles rearrangement reactions}

Synthesis of 2-(trimethylsilyl)phenyl 3',5'-dimethylisoxazole4'-sulfonate, 42

\section{(2-Bromophenoxy)trimethylsilane ${ }^{42}$}

In an oven dried flask, 2-bromophenol $(57.09 \mathrm{mmol}, 9.7 \mathrm{~g}, 6.5$ $\mathrm{mL}, 1$ eq.) in anhydrous THF $(15 \mathrm{~mL})$ was stirred at $\mathrm{rt}$ under nitrogen atmosphere. To this solution 1,1,1,3,3,3hexamethyldisilazane (HMDS) (0.6 eq, $34.25 \mathrm{mmol}, 7.18 \mathrm{~mL}$ ) was added in dropwise by syringe and then heated under reflux for $4 \mathrm{~h}$ at $85{ }^{\circ} \mathrm{C}$. After cooling to $20{ }^{\circ} \mathrm{C}$ the solvent, produced $\mathrm{NH}_{3}$ and unreacted HMDS was evaporated under reduced pressure. The silyl ether was obtained as a colourless oil. Yield $13 \mathrm{~g}(94 \%) .{ }^{1} \mathrm{H}$ NMR confirmed the purity of (2bromophenoxy)trimethylsilane, so without further purification was used for next reaction; $\overline{\boldsymbol{v}}_{\text {max }} / \mathbf{c m}^{-1}$ (ATR): 3061 (=C-H str.), 2959 ( $-\mathrm{C}-\mathrm{H}$ str.), 2899, 1583 (C=C str.), 1474, 1439, 1408, 1283, 1251, 1155, 1120, 1046, 1028; ${ }^{1} \mathbf{H}$ NMR $(400 \mathrm{MHz}$, $\left.\mathrm{CDCl}_{3}\right): \delta=7.45\left(1 \mathrm{H}, \mathrm{dd}, J=8.0,1.0 \mathrm{~Hz}, \mathrm{Ar}-\mathrm{H}_{3}\right), 7.10(1 \mathrm{H}, \mathrm{td}$, $\left.J=8.0 \mathrm{~Hz}, 1.0 \mathrm{~Hz}, \mathrm{Ar}-\underline{\mathrm{H}}_{5}\right), 6.72-6.85\left(2 \mathrm{H}, \mathrm{m}, \mathrm{Ar}-\underline{\mathrm{H}}_{6,4}\right), 0.24(9 \mathrm{H}$, s, $\left.3 \times \mathrm{CH}_{3}\right) ;{ }^{13} \mathbf{C}$ NMR $\left(100 \mathrm{MHz}, \mathrm{CDCl}_{3}\right): \delta=152.0\left(\mathrm{C}_{1}\right), 132.9$ $\left(\mathrm{C}_{3}\right), 127.9\left(\mathrm{C}_{5}\right), 122.3\left(\mathrm{C}_{4}\right), 120.4\left(\mathrm{C}_{6}\right), 115.2\left(\mathrm{C}_{2}\right), 0.0\left(\underline{\mathrm{CH}}_{3}\right)$. LRMS (EI) $\mathrm{C}_{9} \mathrm{H}_{13} \mathrm{BrOSi}$ requires 244; found (EI) $244\left[\mathrm{M}^{+\cdot}\right]$ for ${ }^{79} \mathrm{Br}, 246\left[\mathrm{M}^{+}\right]$for ${ }^{81} \mathrm{Br}$.

\section{Synthesis of 2-(trimethylsilyl)phenol ${ }^{42}$}

2-Bromophenoxy)trimethylsilane, $10 \mathrm{~g}, 41 \mathrm{mmol}, 1 \mathrm{eq}$.$) was$ dissolved in dry THF $(50 \mathrm{~mL})$ and cooled to $-78{ }^{\circ} \mathrm{C}$ under nitrogen with continuous stirring. To this solution dropwise of $n$ BuLi (38.5 mL of $1.6 \mathrm{M}$ in hexane, $61.5 \mathrm{mmol}, 1.5$ eq.) was added by syringe. The reaction mixture was stirred for three hours in same temperature, then warmed to rt and stirred for one hour. The reaction mixture quenched by adding saturated ammonium chloride $(10 \mathrm{~mL})$. The reaction mixture was allowed to room temperature and then extracted it with ethyl acetate $(3 \mathrm{x}$ $25 \mathrm{~mL}$ ). The organic phase was washed with water, brine, and dried over $\mathrm{MgSO}_{4}$ and the reaction mixture taken to dryness in vacuo. The obtained light brown oil was purified by flash column chromatography (silica gel, hexane-EtOAc, 10:1) to give the title compound 2-(trimethylsilyl)phenol as colourless oil. Yield 6.31 g (93\%). $\overline{\boldsymbol{v}}_{\text {max }} / \mathbf{c m}^{-1}$ (ATR): 3600-3300 (broad, O-H str.), 3080 (=C-H str.), 2959 ( $-\mathrm{C}-\mathrm{H}$ str.), 1593 (C=C str.), 1436, 1241, 1122,$1072 ;{ }^{1} \mathbf{H}$ NMR $\left(400 \mathrm{MHz}, \mathrm{CDCl}_{3}\right): \delta=7.31(\mathrm{~d}, J=7.0,1$ $\mathrm{H}), 7.11-7.17(\mathrm{~m}, 1 \mathrm{H}), 6.86 \mathrm{HH}, \mathrm{tt}, J=7.0,1.0 \mathrm{~Hz}, 1 \mathrm{H}), 6.51$ $\left(1 \mathrm{H}, \mathrm{d}, J=8.0 \mathrm{~Hz}, \mathrm{Ar}-\underline{\mathrm{H}}_{6}\right), 4.92(1 \mathrm{H}, \mathrm{s}$, broad, $\underline{\mathrm{H}}), 0.26(\mathrm{~s}, 9 \mathrm{H}$, $\left.\mathrm{CH}_{3}\right) ;{ }^{13} \mathrm{CNMR}\left(100 \mathrm{MHz}, \mathrm{CDCl}_{3}\right): \delta=161.3\left(\mathrm{C}_{2}\right), 136.2\left(\mathrm{C}_{6}\right)$, $131.6\left(\mathrm{C}_{4}\right), 126.4\left(\mathrm{C}_{1}\right), 121.6\left(\mathrm{C}_{5}\right), 115.4\left(\mathrm{C}_{3}\right)$. LRMS (EI) $\mathrm{C}_{9} \mathrm{H}_{14} \mathrm{OSi}$ requires 166.0863; found (EI) $166.0864\left[\mathrm{M}^{+}\right],(\Delta=$ $0.87 \mathrm{ppm})$.

Synthesis of 2-(trimethylsilyl)phenyl 3',5;-dimethylisoxazole4'-sulfonate, 42

To the stirred solution of sodium hydride $(1.156 \mathrm{~g}, 48.19 \mathrm{mmol}$, 4 eq.) in dry THF (75 mL) under nitrogen atmosphere 2(trimethylsilyl)phenol ( $2 \mathrm{~g}, 12.048 \mathrm{mmol}, 1$ eq.) was added. The 
reaction mixture was stirred for thirty minutes and then 3,5dimethylisoxazole-4-sulfonyl chloride $\mathbf{1}$ (2.59, $13.25 \mathrm{mmol}, 1.1$ eq.) was added, reaction mixture was allowed to stir for three hour and then poured it into ether $(100 \mathrm{~mL})$. The organic phase was washed with water, brine, dried over $\mathrm{MgSO}_{4}$, and then the reaction mixture taken to dryness in vacuo. The light yellow oil was purified by column chromatography (gradient elution, gradient $10 \rightarrow 70 \%$ EtOAc/ petroleum ether) to obtain pure colourless viscous oil of title compound. Yield 3.71g (95\%). $\mathbf{R}_{f}$ 0.48 (9:1 petroleum ether: EtOAc; v/v); ${ }^{1} \mathbf{H}$ NMR (400 MHz, $\left.\mathrm{CDCl}_{3}\right) \delta 7.38(1 \mathrm{H}, \mathrm{dd}, J=7,2 \mathrm{~Hz}), 7.10-7.19(2 \mathrm{H}, \mathrm{m}), 6.78(1 \mathrm{H}$, $\mathrm{dd}, J=8,1 \mathrm{~Hz}), 2.41(\mathrm{~s}, 3 \mathrm{H}), 2.26(\mathrm{~s}, 3 \mathrm{H}), 0.18(\mathrm{~s}, 9 \mathrm{H}) .{ }^{13} \mathrm{C}$ NMR $\left(100 \mathrm{MHz}, \mathrm{CDCl}_{3}\right) \delta 175.0,158.5,155.0,136.8,133.8$, 131.1, 127.2, 120.0, 115.0, 13.2, 11.2, 0.0. LRMS (ES $\left.{ }^{+}\right)$ $\mathrm{C}_{14} \mathrm{H}_{19} \mathrm{NO}_{4} \mathrm{SSi}$ requires 325; found (ES $\left.{ }^{+}\right) 326[\mathrm{M}+\mathrm{H}]^{+},\left(\mathbf{E S}^{-}\right) 324$ [M-H]: Microanalysis $\mathrm{C}_{14} \mathrm{H}_{19} \mathrm{NO}_{4} \mathrm{SSi}$ requires: C, 51.67, $\mathrm{H}$, $5.88, \mathrm{~N}, 4.3, \mathrm{~S}, 9.85 \%$; Found: C, 52.00, H, 6.18, N, 4.15, S, $9.25 \%$

\subsection{Attempted fluoride-induced $\quad$ Truce-Smiles rearrangements}

\subsubsection{Using TBAF as fluoride source}

According to (GP7) and at room temperature the starting materials were mixed, A solution of TBAF $\left(\mathrm{Bu}_{4} \mathrm{NF}\right)(6 \mathrm{~mL}, 1 \mathrm{M}$ in THF, $6 \mathrm{mmol}, 3$ eq.) was added to $42(0.651 \mathrm{~g}, 2 \mathrm{mmol}, 1$ eq.) in dry acetonitrile $(12 \mathrm{~mL})$. The crude was purified by column chromatography (silica, 10\% diethyl ether, petroleum ether) afforded phenyl 3,5-dimethylisoxazole-4-sulfonate, $10 a$ as a colourless crystalline solid. Yield $0.395 \mathrm{~g}(78 \%)$. $\mathbf{R}_{f} 0.65$ (9:1 petroleum ether: ether; v/v). ${ }^{\mathbf{1}} \mathbf{H}$ NMR $\left(400 \mathrm{MHz}, \mathrm{CDCl}_{3}\right) \delta 2.23$ $(\mathrm{s}, 3 \mathrm{H}), 2.27(\mathrm{~s}, 3 \mathrm{H}), 6.95-6.99(2 \mathrm{H}, \mathrm{m}), 7.17-7.33(3 \mathrm{H}, \mathrm{m})$. ${ }^{13} \mathbf{C}$ NMR $\left(100 \mathrm{MHz}, \mathrm{CDCl}_{3}\right) \delta 176.8,159.4,150.2,131.3$, 129.1, 123.7, 113.4, 13.7, 11.9. LRMS (EI) $\mathrm{C}_{11} \mathrm{H}_{11} \mathrm{NO}_{4} \mathrm{~S}$ requires 253; found (EI) $253\left[\mathrm{M}^{+}\right]$. Microanalysis $\mathrm{C}_{11} \mathrm{H}_{11} \mathrm{NO}_{4} \mathrm{~S}$ requires: C, 52.17, H, 4.38, N, 5.53, S, $12.66 \%$; Found: C, 52.20, $\mathrm{H}, 4.29, \mathrm{~N}, 5.35, \mathrm{~S}, 12.14 \%$. The spectral data for this compound was compatible to the same compound which previously reported 10a.

\subsubsection{Using caesium fluride as a fluoride source}

According to (GP8) the starting materials were mixed, CsF (456 $\mathrm{mg}, 3 \mathrm{mmol}, 3$ eq.) was added to a solution of $\mathbf{4 2}(325 \mathrm{mg}, 1$ mmol, 1 eq. $)$ in dry THF $(10 \mathrm{~mL})$ and the mixture was refluxed at $70{ }^{\circ} \mathrm{C}$ for $16 \mathrm{~h}$. The crude was purified by flash column chromatography $\left(100 \% \mathrm{CH}_{2} \mathrm{Cl}_{2}-100 \%\right.$ EtOAc) afforded phenol as a white solid. Yield $87 \mathrm{mg}(92 \%) .{ }^{1} \mathbf{H}$ NMR $(500 \mathrm{MHz}$, $\mathrm{CDCl}_{3}$ ): $\delta=6.08$ (br. s., $\left.1 \mathrm{H}\right), 6.93-6.97(\mathrm{~m}, 2 \mathrm{H}), 7.02-7.06$ $(\mathrm{m}, 1 \mathrm{H}), 7.30-7.36(\mathrm{~m}, 2 \mathrm{H}) ;{ }^{13} \mathbf{C} \mathbf{N M R}\left(125 \mathrm{MHz}, \mathrm{CDCl}_{3}\right): \delta=$ $115.6,121.1,129.9,155.2$ (spectral data identical to a reference sampoe).

\subsection{Effect of metal on product distribution of rearrangement reactions}

\subsubsection{Reaction between $4 \mathrm{a}$ and $\mathrm{Cu}\left(\mathrm{NO}_{3}\right)_{2} \cdot 3 \mathrm{H}_{2} \mathrm{O}-\mathrm{Cu}_{2} \mathrm{O}$ leading to $10 a$ and $12 a$}

According to (GP9) the starting materials were mixed: 4a (107 $\mathrm{mg}, 0.29 \mathrm{mmol}, 1$ eq.), $\mathrm{Cu}\left(\mathrm{NO}_{3}\right)_{2} .3 \mathrm{H}_{2} \mathrm{O}(4.02 \mathrm{~g}, 16.64 \mathrm{mmol}, 57$ eq.), $\mathrm{Cu}_{2} \mathrm{O}$ (126 mg, $0.876 \mathrm{mmol}, 3$ eq.), $\mathrm{H}_{2} \mathrm{O}$ (32 mL). Purification by silica gel column chromatography gave the isolated products 10a (white crystal, $45 \mathrm{mg}, 62 \%$ ), 12a (white solid, $13 \mathrm{mg}, 18 \%$ ). The spectral data for these compounds were compatible to those compounds which previously reported.

4.10.2. Reaction between $4 \boldsymbol{b}$ and $\mathrm{Cu}\left(\mathrm{NO}_{3}\right)_{2} \cdot 3 \mathrm{H}_{2} \mathrm{O}-\mathrm{Cu}_{2} \mathrm{O}$ leading $8 b, 10 b$ and $12 b$
According to (GP9) the starting materials were mixed: $4 \mathbf{b}$ (250 $\mathrm{mg}, 0.65 \mathrm{mmol}, 1$ eq.), $\mathrm{Cu}\left(\mathrm{NO}_{3}\right)_{2} .3 \mathrm{H}_{2} \mathrm{O}$ (9.03 g, $37.39 \mathrm{mmol}, 57$ eq.), $\mathrm{Cu}_{2} \mathrm{O}$ (281 mg, $1.97 \mathrm{mmol}, 3$ eq.), $\mathrm{H}_{2} \mathrm{O}$ (71 mL). Purification by silica gel column chromatography gave the isolated products $\mathbf{1 0 b}$ (white crystal, $47 \mathrm{mg}, 27 \%$ ), $\mathbf{8 b}$ (colourless, crystalline solid. Yield $90 \mathrm{mg}(68 \%)$ and 12b (white solid, $5 \mathrm{mg}, 3 \%$ ). The spectral data for these compounds was identical to that previously recorded for these compounds.

\subsubsection{Reaction of $4 \mathrm{c}$ with $\mathrm{Cu}\left(\mathrm{NO}_{3}\right)_{2} \cdot 3 \mathrm{H}_{2} \mathrm{O}-\mathrm{Cu} \mathrm{u}_{2} \mathrm{O}$ leading to $\mathbf{1 7}^{25}$}

According to (GP9) the starting materials were mixed: 4c (135 $\mathrm{mg}, 0.32 \mathrm{mmol}, 1$ eq.), $\mathrm{Cu}\left(\mathrm{NO}_{3}\right)_{2} .3 \mathrm{H}_{2} \mathrm{O}$ (4.40 g, $18.24 \mathrm{mmol}, 57$ eq.), $\mathrm{Cu}_{2} \mathrm{O}$ (137.35 mg, $0.96 \mathrm{mmol}, 3$ eq.), $\mathrm{H}_{2} \mathrm{O}$ (35 mL). Purification by silica gel column chromatography gave the title compound as reddish-brown solid. Yield $38.62 \mathrm{mg}(71 \%)$. ${ }^{1} \mathbf{H}$ NMR $\left(400 \mathrm{MHz}, \mathrm{CDCl}_{3}\right) \delta 6.59(\mathrm{~d}, J=9.0 \mathrm{~Hz}, 1 \mathrm{H}), 7.17-7.23$ (m, $2 \mathrm{H}), 7.44$ (ddd, $J=8.0,7.0,1.0 \mathrm{~Hz}, 1 \mathrm{H}), 7.51$ (dd, $J=1.0 \mathrm{~Hz}$, $1 \mathrm{H}), 7.57(\mathrm{~d}, J=9.0 \mathrm{~Hz}, 1 \mathrm{H}) .{ }^{13} \mathbf{C}$ NMR $\left(100 \mathrm{MHz}, \mathrm{CDCl}_{3}\right) \delta$ 77.2, 119.7, 124.7, 125.6, 125.9, 127.2, 129.8, 130.1, 140.3, 180.2. LRMS Calculated $\mathrm{C}_{10} \mathrm{H}_{6} \mathrm{~N}_{2} \mathrm{O}, 170$, observed LRMS $\left(\mathbf{E S}^{+}\right) 171\left[\mathrm{M}+\mathrm{H}^{+}\right], 193\left[\mathrm{M}+\mathrm{Na}^{+}\right]$; HRMS $\left(\mathbf{E S}^{+}\right)$calculated $\mathrm{C}_{10} \mathrm{H}_{6} \mathrm{~N}_{2} \mathrm{ONa}\left[\mathrm{M}+\mathrm{Na}^{+}\right]$193.0372, observed $193.0365(\Delta=-3.8$ $\mathrm{ppm})$. This spectral data is in good agreemet to that reported in the literature. ${ }^{25}$

\subsubsection{Reaction of $4 \boldsymbol{e}$ with $\mathrm{Cu}\left(\mathrm{NO}_{3}\right)_{2} \cdot 3 \mathrm{H}_{2} \mathrm{O}-\mathrm{Cu}_{2} \mathrm{O}$ leading to $\mathbf{1 0 b}$ and 41}

According to (GP9) the starting materials were mixed: 4e (333 $\mathrm{mg}, 0.87 \mathrm{mmol}, 1$ eq.), $\mathrm{Cu}\left(\mathrm{NO}_{3}\right)_{2} .3 \mathrm{H}_{2} \mathrm{O}$ (12.03 g, $49.80 \mathrm{mmol}, 57$ eq.), $\mathrm{Cu}_{2} \mathrm{O}$ (375 mg, $2.62 \mathrm{mmol}, 3$ eq.), $\mathrm{H}_{2} \mathrm{O}$ (95 mL). Purification by silica gel column chromatography afforded 10b and 41.

\section{m-Tolyl 3,5-dimethylisoxazole-4-sulfonate, $\mathbf{1 0 b}$}

Isolated as a colourless, amorphous solid. Yield $56 \mathrm{mg}(24 \%)$. The spectral data for this compound was identical to that recorded for compound $\mathbf{1 0 b}$, obtained from the reaction between 4b with $\mathrm{TiCl}_{3}$, experiment 4.4.2 (Scheme 5).

4-Hydroxy-3-methylphenyl 3',5'-dimethylisoxazole-4-sulfonate, 41

Brown-colured solid. Yield $175 \mathrm{mg}(71 \%)$. mp. $=88-90{ }^{\circ} \mathrm{C} ; \mathbf{R}_{f}$ 0.27 (2:8 ethyl acetate: hexane; v/v); $\overline{\boldsymbol{v}}_{\max } / \mathbf{c m}^{-1}$ (ATR) 36133483, 3042, 2962, 1589, 1503, 1438, 1409, 1379, 1359, 1269, 1199, 1184, 1122, 1041, 999, 944, 911, 878, 826, 763. ${ }^{\mathbf{1}} \mathbf{H}$ NMR (500 MHz, CDCl3): $\delta=2.14(\mathrm{~s}, 3 \mathrm{H}), 2.27(\mathrm{~s}, 3 \mathrm{H}), 2.34(\mathrm{~s}, 3 \mathrm{H})$, 4.94 (br. s., $1 \mathrm{H}), 6.60-6.67$ (m, $2 \mathrm{H}), 6.78$ (d, J=3.0 Hz, $1 \mathrm{H})$; ${ }^{13}$ C NMR $\left(125 \mathrm{MHz}, \mathrm{CDCl}_{3}\right) \delta 10.7,12.5,15.8,112.2,115.5$, $120.5,124.6,125.7,142.1,153.1,158.2,175.3$. LRMS (ES $\left.{ }^{+}\right)$ $\mathrm{C}_{12} \mathrm{H}_{13} \mathrm{NO}_{5} \mathrm{~S}$ requires 283 ; found $\left(\mathbf{E S}^{+}\right) 284[\mathrm{M}+\mathrm{H}]^{+}, 306$ $\left[\mathrm{M}+\mathrm{Na}^{+}\right], \quad\left(\mathbf{E S}^{-}\right) \quad 282 \quad[\mathrm{M}-\mathrm{H}] ;$; HRMS $\quad\left(\mathbf{E S}^{+}\right) \mathrm{C}_{12} \mathrm{H}_{13} \mathrm{O}_{5} \mathrm{SNNa}$ $[\mathrm{M}+\mathrm{Na}]^{+}$requires 306.0407; found $306.0407(\Delta=0.12 \mathrm{ppm})$.

\subsection{Blank Reactions}

\subsubsection{Reaction between $\mathbf{4 b}$ with $\mathrm{HCl}$}

$3 \mathrm{M} \mathrm{HCl}$ (2.4 mL, $6.4 \mathrm{mmol}, 16$ eq.) was added dropwise to a solution of $\mathbf{4 b}$ (154 mg, $0.40 \mathrm{mmol}, 1$ eq.) in acetone $(3 \mathrm{~mL})$ in sealed vial and under $\left(\mathrm{N}_{2}\right)$ atmosphere at $0{ }^{\circ} \mathrm{C}$. After the addition, the reaction mixture was stirred for $0.5 \mathrm{~h}$ at $0{ }^{\circ} \mathrm{C}$ and then $1 \mathrm{~h}$ at RT. Water $(20 \mathrm{~mL})$ was added to the reaction mixture and several time was extracted with $\mathrm{CH}_{2} \mathrm{Cl}_{2}$. The organic layer was washed with brine, dried over $\mathrm{MgSO}_{4}$ and concentrated in vacuo. The crude product was obtained as sticky brown solid. Initial purificationof the mixture by flash chromatography afforded a mixture of $\mathbf{7 b}, \mathbf{8 b}$, and $\mathbf{1 0 b}$ where the product ratio was 
determined by ${ }^{\mathbf{1}} \mathbf{H}$ NMR analytical HPLC analysis against authentic materials (see supplemenatry information).

\subsubsection{Reaction between $10 \mathrm{c}$ and $\mathrm{TiCl}_{3}$}

According to (GP4) the starting materials were mixed: 10c (200 $\mathrm{mg}, 0.657 \mathrm{mmol}, 1$ eq. $)$, acetone $(3 \mathrm{~mL}), \mathrm{TiCl}_{3}(1.29 \mathrm{M}$ in $\mathrm{HCl}, 2$ eq., $1.02 \mathrm{~mL}, 1.31 \mathrm{mmol}$ ). Work-up, as above, afforded 10c, essentially unchanged, as judged by ${ }^{1} \mathrm{H}$ NMR analysis.

\subsubsection{Reaction between 16 and $\mathrm{TiCl}_{3}$}

According to (GP4) the starting materials were mixed: 2naphthol, 16 (250 mg, $1.73 \mathrm{mmol}, 1$ eq.), acetone ( $3 \mathrm{~mL}), \mathrm{TiCl}_{3}$ (1.29 $\mathrm{M}$ in $\mathrm{HCl}, 2$ eq., $2.68 \mathrm{~mL}, 3.46 \mathrm{mmol})$. Work-up, as above, and chromatography of the residue (silica; 30\% EtOAc: hexane) afforded 16 essentially unchanged, as judged by ${ }^{1} \mathrm{H}$ NMR analysis.

\subsubsection{Reaction between 17 and $\mathrm{TiCl}_{3}$ leading to 16 and 18}

According to (GP4) the starting materials were mixed: 17 (60 $\mathrm{mg}, 0.34 \mathrm{mmol}, 1$ eq.), acetone $(0.54 \mathrm{~mL}), \mathrm{TiCl}_{3}(1.29 \mathrm{M}$ in $\mathrm{HCl}$, 2 eq., $1.02 \mathrm{~mL}, 1.31 \mathrm{mmol})$. Purification of the crude product by column chromatography silica; gradient elution: $10 \%$ to $30 \%$ EtOAc:hexane) afforded $\mathbf{1 6}$ and $\mathbf{1 8}$ :

\section{Naphthalen-2-ol, 16}

Colourless, crystalline solid. Yield $31 \mathrm{mg}(63 \%) . \quad \mathbf{R}_{f} 0.87$ (100\% EtOAc). ${ }^{1} \mathbf{H}$ NMR $\left(400 \mathrm{MHz}, \mathrm{CDCl}_{3}\right) \delta 5.44$ (br. s., $\left.1 \mathrm{H}\right), 7.13-$ $7.20(\mathrm{~m}, 2 \mathrm{H}), 7.36-7.41(\mathrm{~m}, 1 \mathrm{H}), 7.48$ (ddd, $J=8.2,6.9,1.3 \mathrm{~Hz}$, $1 \mathrm{H}), 7.71(\mathrm{dd}, J=8.3,0.50 \mathrm{~Hz}, 1 \mathrm{H}), 7.78-7.84(\mathrm{~m}, 2 \mathrm{H}) .{ }^{13} \mathbf{C}$ NMR $\left(100 \mathrm{MHz}, \mathrm{CDCl}_{3}\right) \delta 109.6,117.8,123.7,126.4,126.6$, $127.8,128.9,129.9,134.6,153.3$. This data was essentially identical to that recorded on an authentic sample (ex Aldrich).

\section{1-chloronaphthalen-2-ol, $18^{44}$}

Colourless, crystalline solid. Yield $19 \mathrm{mg}(31 \%)$, mp. $67-68{ }^{\circ} \mathrm{C}$ $\left(\right.$ Lit $\left.^{44} 66^{\circ} \mathrm{C}\right),{ }^{1} \mathbf{H}$ NMR $\left(500 \mathrm{MHz}, \mathrm{CDCl}_{3}\right) \delta 6.35(\mathrm{~s}, 1 \mathrm{H}), 7.42$ $(\mathrm{d}, J=8.0 \mathrm{~Hz}, 1 \mathrm{H}), 7.47-7.53(\mathrm{~m}, 1 \mathrm{H}), 7.67$ (ddd, $J=8.0,7.0$, $1.0 \mathrm{~Hz}, 1 \mathrm{H}), 7.73(\mathrm{~d}, J=8.0 \mathrm{~Hz}, 1 \mathrm{H}), 7.84(\mathrm{~d}, J=8.0 \mathrm{~Hz}, 1 \mathrm{H})$, $8.19(\mathrm{~d}, J=8.0 \mathrm{~Hz}, 1 \mathrm{H}) .{ }^{13} \mathbf{C}$ NMR $\left(125 \mathrm{MHz}, \mathrm{CDCl}_{3}\right) \delta 113.6$, $117.4,122.9,124.3,127.7,128.4,128.6,129.6,131.2,149.5$. LRMS (EI) $\mathrm{C}_{10} \mathrm{H}_{7} \mathrm{ClO}$ requires 178; found GC-MS (EI) 178 $[\mathrm{M}]^{+}$for ${ }^{35} \mathrm{Cl}, 180$ for ${ }^{37} \mathrm{Cl}$. This data is essentially identical to that reported in the literature for this compound. ${ }^{44}$

\subsubsection{Reaction between $4 \mathrm{c}$ and $\mathrm{HCl}$ leading to 17}

To a solution of $4 \mathbf{c}(84 \mathrm{mg}, 0.20 \mathrm{mmol})$ in acetone $(2 \mathrm{~mL}),(3 \mathrm{M}$, $\mathrm{HCl}, 3 \mathrm{~mL})$ was added and stirred under $\left(\mathrm{N}_{2}\right)$ gas for $2 \mathrm{~h}$. Water $(10 \mathrm{ml})$ was added and extracted by $\mathrm{CH}_{2} \mathrm{Cl}_{2}(3 \times 15 \mathrm{~mL})$. Workup as above and chromatography of the residue (silica gel: $30 \%$ EtOAc: hexane) afforded $\mathbf{1 7}$ as a redish-coloured solid. Yield 23 $\mathrm{mg}(68 \%)$. The spectral data for this compound was identical to the material isolated in experiment 4.10.3.

\section{X-ray Data}

Crystallographic data (excluding structure factors) for compounds 3a, 3b, 3c, 3e, 8b, 8c, 8d, 9b, 10a, 10b, 10c, 10d, 12a, 12c, 12d, 13a, 13d and 21 have been deposited with the Cambridge Crystallographic Data Centre. Copies of the data (CCDC nos. CCDC 1891090-1891107) can be obtained free of charge via www.ccdc.cam.ac.uk/conts/retrieving.html (or from the Cambridge Crystallographic Data Centre, 12 Union Road, Cambridge CB21EZ, UK; fax: (+44)1223-336-033; or deposit@ccdc.cam.ac.uk).

\section{Acknowlefgements}

The UoM thanks the EPSRC (EP/K039547/1) for the provision of Bruker NMR spectrometers and an Agilent SuperNova X-ray diffractometer. S. O. R. thanks the Kurdistan Regional Government for the provision of a research studentship.

\section{Competing interests}

The authors declare no competing interests.

\section{References}

1. Truce, W. E.; Ray, W. J.; Norman, O. L.; Eickemeyer, D. B. J. Am. Chem. Soc. 1958, 80, 3625; Truce, W. E. Sulfur Reports 1990, 9, 351

2. Henderson, A. R. P.; Kosowan, J. R.; Wood, T. E. Can. J. Chem. 2017, 95, 483.

3. See, for example: Coulibali, S.; Deruer, E.; Godin, E.; Canesi, S. Org. Lett. 2017, 19, 1188.

4. Holden, C. M.; Greaney, M. F. Chem. Eur. J. 2017, 23, 8992

5. (a) Loven, R.; Speckamp, W. N. Tetrahedron Lett. 1972, 1567; (b) Allart-Simon, I.; Gérard, S.; Sapi, J. Molecules, 2016, 21, 878; (c) Chen, Z.-M.; Zhang, X.-M.; Tu, Y.-Q. Chem. Soc. Rev. 2015, 44, 5220

6. Li, W.; Xu, W.; Xie, J.; Yu, S.; Zhu, C. Chem.Soc. Rev. 2018, 47, 654.

7. (a) Motherwell, W. B.; Pennell, A. M. K. J. Chem. Soc., Chem. Commun. 1991, 877; (b) da Nata, M. L. E. N.; Motherwell, W. B.; Ujjainwalla, F. Tetrahedron Lett. 1997, 38, 137; (c) da Mata, M. L. E. N.; Motherwell, W.B.; Ujjainwalla, F. Tetrahedron Lett. 1997, 38, 141; (d) Ujjainwalla, F.; da Mata, M. L. E. N.; Pennell, A. M. K.; Escolano, C.; Motherwell, W. B.; Vázquez, S. Tetrahedron 2015, 71, 6701.

8. (a) Gurry, M.; Aldabbagh, Org. Biomol. Chem. 2016, 14, 3849; (b) Chatgilialoglu, C.; Griller, D.; Lesage, M. J. Org. Chem. 1988, 53, 3642; (c) for the use of TTMSS in radical, bi-aryl, syntheses see: Martínez-Barrasa, García de Viedma, A.; Burgos, C.; Alvarez-Builla, J. Org. Lett. 2000, 2, 3933.

9. See Andrieux, C. P.; Pinson., J. J. Am. Chem. Soc. 2003, 125, 14801 and refs. therein.

10. Shaefer, W. E.; Becker, W. W. Anal. Chem. 1947, 19, 307; (b) Barek, J.; Berka, A.; Borek, V. Michrochemical J. 1979, 24, 503; (c) Boar, R. B.; McGhie, J. F.; Robinson, M.; Barton, D. H. R. ; Stick, R. V. J. Chem. Soc., Perkin Trans 1 1975, 1237; (d) Barton, D. H. R.; Bowles, T. B.; Husinec, S.; Forbes, J. E.; Llobera, A.; Porter, A. E. A.; Zard, S. Z. Tetrahedron Lett. 1988, 29, 3343.

11. (a) Lesur, B.; Yue, C.; Chasset, S.; Renault, O. WO 2005100345 A1, 2005; PCT Int. Appl.; (b) for a Ti-mediated biaryl synthesis resulting from the decomposition of an aryl diazonium salt see Caronna, T. ; Ferrario, F.; Servi, S. Tetrahedron Lett. 1979, 20, 657.

12. (a) For a review of aromatic substitution reactions which utilize diazonium salts see: Koziakov, D.; Wu, G.; von Wangelin, A. J. Org. Biomol. Chem. 2018, 16, 4942; (b) For a review of related Gombergtype arylations see: Hofmann, J.; Gans, E.; Clark, T.; Heinrich, M. R. Chem. Eur. J. 2017, 23, 9647; (c) Meerwein-type reactions: Heinrich, M. R.; Chem. Eur. J. 2009, 15, 820; (d) Fehler, S. K.; Heinrich, M. R.; Synlett 2015, 26, 580; (e) Kindt, S.; Heinrich, M. R. Synlett, 2016, 48, 1597; (f) Oger, N.; Felpin, F-X. ChemCatChem. 2016, 8, 1998; (g) Oger, N.; d'Halluin, M.; Le Grognec, E.; Felpin, F-X. Org. Process Res. Dev. 2014, 18, 1786.

13. Bonfand, E.; Forslund, L.; Motherwell, W. B.; Vázqez, S. Synlett, 2000, 475.

14. For an overview of isoxazoles in medicinal chemistry see $\mathrm{Zu}$, J.; Mo, J.; Lin, H-Z.; Chen, Y.; Sun, H-P. Biorganic Med. Chem. 2018, 26, 3065.

15. Cremlyn, R. J.; Swinbourne, F. J.; Yung, K-M. J. Het. Chem. 1981, 18, 997.

16. Mo. F.; Dong, G.; Wang, J. Org. Biomol. Chem. 2013, 11, 1582.

17. (a) Beckwith, A. L. J.; Norman, R. O. C. J. Chem. Soc. (B) 1969, 403; (b) Ashworth, B.; Gilbert, B. C.; Norman, R. O. C. J. Chem. Res. (S) 1977, 94.

18. (a) Suehiro, T.; Masuda, S.; Nakausa, R.; Taguchi, M.; Mori, A.; Koike, A.; Date, M. Bull. Chem.Soc. Jpn. 1987, 60, 3321; (b) Galli, C. Chem. Rev. 1988, 88, 765; Daasbjerg, K.; Sehested, K. J. Phys. Chem. A 2002, 106, 11098

19. For recent theoretical treatments of radical arylation reactions see: (a) Hofmann, J.; Clark, T.; Heinrich, M. R. J. Org. Chem. 2016, 81, 9785; (b) Zhang, X. Int. J. Quantum. Chem. 2015, 115, 1658.

20. Fehler, S. K.; Pratsch, G.; Heinrich, M. R. Angew. Chem. Int. Ed. 2014, 53, 11361.

21. c.f. (a) Stephen, M. J.; Hinshelwood, C. J. Chem Soc. 1955, 1393; (b) Barek, J.; Berka, A.; Borek, V. Michrochemical Journal 1979, 24, 503. 
22. (a) For a review of "classical" Sandmeyer coupling reactions see: Hodgson, H. H. Chem. Rev. 1947, 40, 251; (b) for more recent developments see: Mo, F.; Qiu, D.; Zhang, Y.; Wang, J.; Acc. Chem. Res., 2018, 51, 496.

23. Beringer, F. M.; Bodlaender, P. J. Org. Chem. 1969, 34, 1981.

24. (a) For a recent example of a process involving the generation and subsequent capture of aryl cations derived from aryl diazonium salts see: Wang. H.; Xu, Q.; Shen, S.; Yu, S. J. Org. Chem. 2017, 82, 770; (b) For an overview of S.E.T-ligand transfer reactions see: Zhang, N.; Samanta, S. R.; Rosen, B. M.; Percec, V. Chem Rev. 2014, 114, 5848; (c) for a detailed mechanistic assessmnt of the Sandmeyer reaction see: Hanson, P.; Jones, J. R.; Taylor, A. B.; Walton, P. H.; Timms, A. W. J. Chem. Scoc., Perkin Trans. 2 2002, 1135.

25. Kitamura, M.; Otsuka, K.; Takahashi, S.; Okauchi, T. Tetrahedron Lett. 2017, 58, 3508 .

26. Cohen, T.; Dietz, A. G. Jr.; Miser, J. R. J. Org. Chem. 1977, 42, 2053.

27. $c f$. (a) Maas, G.; Tretter, A. Liebigs Ann. Chem. 1985, 1866; (b) Colas, C.; Goeldner, M. Eur. J. Org. Chem. 1999, 1357.

28. (a) Khan, R.; Boonseng, S.; Kemmitt, P. D.; Felix, R.; Coles, S. J.; Tizzard, G. J.; Williams, G.; Simmonds, O.; Harvey, J.-L.; Atack, J.; Cox, H.; Spencer, J. Adv. Synth. Catal. 2017, 359, 3261; (b) Bunnett, J. F.; Zahler, R. E. Chem. Rev. 1951, 49, 273; (c) Panetta, C. A.; Fang, Z.; Heimer, N. E. J. Org. Chem. 1993, 58, 6146.

29. For TM complexes of aryldiazonium salts see: Obushak, N. D.; Lyakhovich, M. B.; Bilaya, E. E. Russ. J. Org. Chem. 2002, 38, 38.

30. (a) For similar reactions using Rh- or Pd-catalysis see: (a) Kitamura, M.; Kisanuki, M.; Sakata, R.; Okauchi, T. Chem. Lett. 2011, 40, 1129; (b) Baral, E. R.; Rok, Y. R.; Kim, S. H.; Wee, Y-J. Synthesis, 2016, 48, 579; (c) for other Ti-promoted halogen incoporation reactions see: Clerici, A.; Porta, Ombretta. Tet. Lett. 1987, 28, 1541.

31. Pratsch, G.; Anger, C.; Ritter, K.; Heinrich, M. R. Chem. Eur. J. 2011, $17,4104$.

32. Cuerva, J. M.; Campaña, J. Justicia, A. Rosales, Oller-López, J. L.; R. Robles, Cárdenas, D. J.; Buñuel, E.; Oltra, J. E. Angew. Chem. Int. Edn. 2006, 45,5522 .

33. We are aware of only one other report of this ring system: see Feroze Ujjainwalla, F., PhD thesis, Department of Chemistry, Imperial College, 1993.

34. (a) Studies on the addition of radicals to isoxazoles are scant, see: Dogan, I.; Steenken, S.; Schulte-Frohlinde, D.; Içli, S. J. Phys. Chem. 1990, 94, 1887, (b) for nucleophilic addition to activated isoxazoles see: Lee, C. K. Y.; Herlt, A. J.; Simpson, G. W.; Willis, A. C.; Easton, C. J. J. Org. Chem. 2006, 71, 3221; Kawai, H.; Sugita, Y.; Tokunaga, E.; Sato, H.; Shiro, M.; Shibata, N. ChemistryOpen 2014, 3, 14.

35. See Mattingly, P. G.; Miller, M. J. J. Org. Chem. 1980, 45, 410 and references therein.

36. $c f$. Das, N. B.; Torsell, K. B. G. Tetrahdron 1983, 39, 2247.

37. (a) for the rate of adition of phenyl radicals to furan see: Burkey, T. J.; Griller, D.; Lunazzi, L.; Nazran, A. S. J. Org. Chem. 1983, 48, 3704; (b) for synthetic applications see: Monzón, D. M.; Santos, T.; PinachoCrisóstomo;Martín, V. S.; Carillo, R. Chem. Asian. J. 2018, 13, 32; (c) Johnston, L. L.: Lusztyk, J.; Wayner, D. D. M.; Abeywickrema, A. N.; Beckwith, A. L. J.; Scaiano, J. C.; Ingold, K. U. J. Am. Chem. Soc. 1985, 107, 4594.

38. (a) For the use of radical-clocks in related systems see: Perry, G. J. P.; Quibell, J. M.; Panigrahi, A.; Larossa, I. J. Am. Chem. Soc. 2017, 139, 11527; (b) Johnston, L. J.; Lusztyk, J.; Wayner, D. D. M; Abeywickreyma, A. N.; Beckwith, A. L. J.; Scaiano, J. C.; Ingold, K. U. J. Am. Chem. Soc. 1985, 107, 4594.

39. For radical-like behavior of putative alkyltitanium(IV) species see: Matsumura, Y.; Nishimura, M.; Hiu, H.; Watanabe, M.; Kise, N. J. Org. Chem. 1996, 61, 2809.

40. For related halo-cyclization reactions see: (a) Ouyang, J.; Su, X.; Chen, Y.; Yuan, Y.; Li, Y. Tetrahedron Lett. 2016, 57, 1438; (b) Yang, X.; Liu, W.; Li, L.; Wei, W.; Li, C-J. Chem. Eur. J. 2016, 22, 1252; (c) Hartmann, M.; Gerleve, C.; Studer, A. Synlett 2016, 27, 725; (d) Guo, R.; Yang, H.; Tang, P. Chem. Commun. 2015, 51, 8829; (e) Hartmann. M.; Studer, A. Angew. Chem. Int. Ed. 2014, 53, 8180; (f) Petrone, D. A.; Lischka, M.; Lautens, M. Angew. Chem. Int. Ed. 2013, 52, 10635; (g) Yanada, R.; Obika, S.; Nishimori, N.; Yamauchi, M.; Takemoto, Y. Tetrahedron Lett. 2004, 45, 2331; (h) Whitemore, M.; Heindel, N.; Guillon, C.; McNeil, T.; Rapp, R.; Mariano, T.; Heck, D.; Laskin, J. Heterocycles 2001, 55, 1081.

41. (a) For the presumed generation of ortho-hydroxyaryl radicals via the reduction of ortho-diazophenols see: Runge-Eschen, F.; Helbig, G. Propellants, Explosives Pyrotechnics 1982, 7, 148 and ref. 31; (b) Beckwith, A. L. J.; Meijs, G. F. J. Chem. Soc., Chem. Comm. 1981, 136.
42. Rasheed, O. K.; Hardcastle, I. R.; Raftery, J.; Quyale. P. Org. Biomol. Chem. 2015, 13, 8048 .

43. Zarate, C.; Martin, R. J. Am. Chem. Soc. 2014, 136, 2236.

44. Mishra, A. K.; Nagarajaiah, H.; Moorthy, J. N. European J. Org. Chem. 2015, 2733. 